\title{
Studia
}

\section{Poland AND the BRezhnev Doctrine (1968-1989)}

\section{ANTHONY Kemp-Welch}

\author{
EMERITUS READER, \\ SCHOOL OF HISTORY, \\ UNIVERSITY OF EAST ANGLIA, UK \\ mail: tonykempwelch@gmail.com \\ ORCID: https://orcid.org/0000-0002-0001-6876
}

After the Sovietled invasion of Czechoslovakia in August 1968, Moscow began to advance the notion of "limited sovereignty", soon dubbed by Washington the "Brezhnev Doctrine". The Doctrine was next debated during the period of Solidarity (1980-81) when Soviet leaders considered the pros and cons of a military invasion. After sixteen months of hesitation, the domestic "martial law" alternative was chosen instead. In the late eighties, Gorbachev advised his Eastern European counterparts that violence was no longer an option and that they should therefore reach peaceful accommodations with their own societies. Jaruzelski was the first to do so.

\section{Keywords}

Brezhnev doctrine, limited sovereingty, Cold War, Soviet invasion, Solidarity, Polish crisis, perestroika, Round Table 
"To Hell with Sovereignty" Gomułka, 1968

The notion of sovereignty was first developed by Dutch jurists in the sixteenth century. Hugo Grotius's use of the term summum imperium suggests that a territory and its ruler are the patrimony of the ruler, to be bartered at his will. ${ }^{1}$ But it is not until much later that this evolved into the notion that all states had the inherent right to independence of outside authority in the control of its territory and population. That required the diplomatic system to be accepted as the concern of international society as a whole, and recognised as "public international law." The Congress of Vienna's Final Act formalised this and brought it into conformity with the doctrine of the sovereign equality of states. "Equality" in this sense, which meant the like enjoyment of like rights of sovereignty, naturally presupposed the existence of statehood. Poland was not able to enjoy this during the long nineteenth century.

The first international organisation in modern history, the League of Nations, attempted to restrict the exercise of state sovereignty by imposing obligations on its member states to recognise the international order as superior to their individual interests. Far from denying the sovereignty of members states, however, the Covenant ensured its continuation by confining the League to an advisory function on matters of security, requiring unanimity as a precondition of action and permitting withdrawal from membership. ${ }^{3}$ It could not prevent the fourth partition of Poland in September 1939.

World War Two diplomacy again addressed issues of sovereignty. The Atlantic Charter (August 1941) stated "territorial adjustments must be made with the wishes of the people concerned" and "all people have a right to self-determination." Given its ambitions to annex Danzig and East Prussia and parts of German Silesia, the Polish government-in-exile asked Churchill for a "flexible" interpretation of this principle. The Yalta "Declaration on Liberated Europe" (February 1945) was also ambiguous. To expect that Stalin would countenance free and fair elections on territory the Red Army had so recently liberated seemed fanciful. As he confided to Djilas: "This war is not as in the past; whoever occupies a territory also imposes on it his own social system. Everyone imposes his own system as far as his army has power to do so. It cannot be otherwise." ${ }^{\prime 4}$ Roosevelt had already made a secret understanding with Stalin to move Poland's boundaries 200 kilometres to the west. $^{5}$ Churchill was not informed of this agreement. Krystyna Kersten notes "FDR thought issues such as Poland and Romania would be resolved within the UNO."

${ }^{1}$ F. Parkinson, The Philosophy of International Relations. A study in the history of thought, London, 1977, pp. 34-39.

${ }^{2}$ H. Bull, The Anarchical Society. A Study of Order in World Politics, London 1977, pp. 37-38.

${ }^{3}$ F.H. Hinsley, Power and the Pursuit of Peace. Theory and Practice in the History of Relations between States, Cambridge 1967, Ch. 13.

${ }^{4}$ M. Djilas, Conversations with Stalin, London 1963, p. 90.

${ }^{5}$ S. Kudryashov, Diplomatic Prelude [in:] Stalinism in Poland, 1944-1956. Selected Papers from the Fifth World Congress of Soviet and East European Studies, Warsaw, 1995, ed. A. Kemp-Welch, New York 1999, p. 36.

${ }^{6}$ K. Kersten, The Establishment of Communist Rule in Poland, 1943-1948, Berkeley 1991, p. 120. 
Sovereignty was enshrined in the UN Charter. "Purposes and Principles" (Chapter 1) states: "The Organisation is based on the principle of the sovereign equality of all its Members" but also warns: "Nothing contained in the present Charter shall authorise the United Nations to intervene in matters which are essentially within the domestic jurisdiction of any state." It adds, somewhat paradoxically, "this principle shall not prejudice the application of enforcement measures (Chapter V11) "Action with Respect to Threats to the Peace, Breaches of the Peace and Acts of Aggression." Since the permanent members of the Security Council received a veto over the Organisation, which could not act against them, five members were more sovereign than others. As the Cold War developed, the superpowers increasingly asserted authority over other states within their "own sphere".

The Truman Doctrine, 1947 (Greece and Turkey) stated "it must be the policy of the United States to support free peoples who are resisting attempted subjugation by armed minorities or by outside pressures"? This meant the Soviet threat, though initially seen as political and psychological rather than military. One of its chief architects, George Kennan, noted "the weakness of the Russian position, the slenderness of the means with which they operated and the ease with which they could be held and pushed back". Consequently, the US should focus on "out-producing the world", controlling the seas and retaining the capacity to "strike inland with the atomic bomb." " However, the Soviet Union acquired nuclear weapons far sooner than the US had anticipated, and by the mid-fifties a thermonuclear stalemate was reached, uncomfortably entitled "mutually-assured destruction". In this new context, the notion of "rolling back" communism was redundant and the ability of each super-power to intervene in each other's spheres was effectively removed. Hence, despite much psychological and political propaganda, the US and its NATO allies were unable to provide any military support to the Hungarian insurgency in autumn $1956 .{ }^{9}$

Although a Brezhnev Doctrine, 1968 (Czechoslovakia) was not acknowledged by Soviet leaders until almost the end of their rule, it provides a convenient short-hand for considering the role of force and other aspects of their troubled relationship with Eastern Europe. The phrase was coined by American analysts after the Warsaw Pact invasion to end the "Prague Spring." Its essence is a notion of "limited sovereignty" whereby the "international interests of socialism" (all undefined) take precedence over the sovereign claims of any single socialist state. Yet, as the outstanding historian of the Prague Spring notes, the doctrine "simply put in formal legal terms a proposition frequently stated. It reiterated the right of intervention so often asserted and implemented in earlier decades of Soviet rule." 10

\footnotetext{
${ }^{7}$ B. Loveman, No Higher Law: American Foreign Policy and the Western Hemisphere since 1776, North Carolina 2010, p. 317.

${ }^{8}$ M. Leffler, The emergence of an American grand strategy, 1945-1952 [in:] The Cambridge History of the Cold War Volume 1 Origins, eds. M. Leffler and O.A. Westad, Cambridge 2010, pp. 77-78.

${ }^{9}$ Ch. Gati, Failed Illusions. Moscow, Washington, Budapest, and the 1956 Hungarian Revolt, Stanford 2006.

${ }^{10}$ H.G. Skilling, Czechoslovakia's Interrupted Revolution, Princeton 1976, p. 730.
} 
We will analyse the Doctrine in three phases:

(1) Articulation considers the various positions adopted by other members of the Warsaw Pact, particularly Gomułka, in relation to the "Prague Spring."

(2) Ambivalence concentrates on the 'non-invasion' of Poland during the sixteen months of Solidarity, 1980-81.

(3) Annulment traces its demise.

The Doctrine did not die with Brezhnev in 1982 but continued to be a policy option until the end of Soviet rule. Whilst there are no crises in Eastern Europe during the post-Brezhnev succession years, when the Soviet Union was fully engaged in Afghanistan, the use of force is not ruled out. A new collection of documents from the Gorbachev Foundation contains a section "The End of the Brezhnev doctrine." They cover February 1986-October 1989. ${ }^{11}$

Our main primary sources are from the Polish Archive of Modern Acts (AAN) in Warsaw. They are supplemented by Russian state archives (TsKhSD/RANI) and those of the Gorbachev Foundation (AGF) in Moscow, and three in the United States: the National Security Archive (NSA) in Washington, the Hoover Institution at Stanford University, and the Lyndon B. Johnson Presidential Library in Austin, Texas. The author took part in two critical oral history conferences convened by the Polish Academy of Sciences' Institute of Political Studies (ISP PAN) on international policies towards Poland from 1980-1982 ${ }^{12}$ and 1986-1989. ${ }^{13}$ Attended by key decision-makers, East and West, they provide much evidence for policy at these crucial junctures. Sergei Kudryashov (Moscow), whose team has recently transcribed the Brezhnev diaries $^{14}$, continues to be the vital guide to Russian archives. Equally essential are the research and abundant publications of Mark Kramer (Harvard).

\section{Part One: Articulation}

Khrushchev's "Secret Speech" (February 1956) was translated and widely circulated in Poland. ${ }^{15}$ Although his original intention was to remedy past failings, he was soon concerned to restrict future discussions. At a May Day lunch, he accused the new Polish leadership of turning their backs on Moscow. "We are going to fight against that", he declared, banging the table. Pointing at the Polish Ambassador, he shouted: "You have your sovereignty, but what you are doing today in Poland is against your sovereignty, and against socialism. We deeply regret the death of comrade Bierut who was a communist internationalist. Ochab has allowed anti-socialist elements to have their own way in Poland. They need to be wrapped across the knuckles." ${ }^{\prime 16}$

\footnotetext{
${ }^{11}$ Otvechaya na vuizov vremeni. Vneshnyaya politika perestroiki: dokumental'nie svidetel'stva. Po zapisyam besed M. S.Gorbacheva c zarubezhnimi deyatelyami i drugim materialam, Moscow 2010, pp. 515-574.

${ }^{12}$ Wejdq nie wejdq. Polska 1980-1982: wewnetrzny kryzys, międzynarodowe uwarunkowania. Konferencja w Jachrance listopad 1997, Londyn 1999.

${ }_{13}$ Polska 1986-1989: koniec system. Materialy międzynarodowej konferencji, Miedzeszyn, 21-23 październik. 1999, vol. 1 Referaty, vol. 2 Dyskusja, vol. 3 Dokumenty, Warszawa 2002.

${ }^{14}$ Leonid Brezhnev. Rabochi i dnevnikove zapisach V 3-x tomach, Moscow 2016.

${ }^{15}$ A. Kemp-Welch, Dethroning Stalin. Khrushchev's 'Secret Speech' and Polish Politics, The Spring of 1956, "Europe-Asia Studies" 2006, Vol. 48 (2).

${ }^{16}$ V. Micunovic, Moscow Diary, London 1980, p. 144.
} 
The Poznan protests (28 June) showed how quickly an economic demonstration, concerning work norms and prices, could turn into a political and national manifestation. Within hours, crowds had moved from chanting "We want Bread" to "We want Freedom" and "We want UN- supervised elections". ${ }^{17}$ In Budapest, the Petofi Circle discussion club attracted hundreds of participants. But Khrushchev denounced the "subversive activities of the imperialists in Poznan and Hungary" at the Soviet Presidium (9 and 12 July): “They want to weaken internationalist ties and in the name of sindependent roads« want to foment disunity and destroy (the socialist countries) one by one". ${ }^{18}$ The "anti-Stalin campaign" was abruptly halted and Pravda announced that the time for "self-criticism" was over. $^{19}$

Poland regained significant elements of sovereignty in October 1956. Collective agriculture - a major Stalinist priority - was abandoned and the Catholic Church was restored to its place in public life. Minister of Defence, Marshal Rokossovskii, was sent back to Moscow and relations with the Soviet Union were put on a more equal footing. Precise imitation of the Soviet model was no longer obligatory. Bi-lateral negotiations in Moscow (November 1956) confirmed that each country could find its own "methods, forms and paths for building socialism" according to their "particular historical conditions and national requirements". Of course, this did not mean all "roads to socialism" would be accepted, but the boundaries were undefined. The future of millions of citizens deported to the East in the first Soviet occupation (1939-41), or now living in territories incorporated into the USSR from 1944, remained unresolved. ${ }^{20}$

Unnerved by the Soviet invasion of Hungary, the restored Polish leader Gomułka realised his country could have suffered the same fate. After a brief intellectual resurgence, known in the jargon as "revisionism", he moved to foreclose public debates. The independent Po Prostu, which published a negative balance-sheet on the first anniversary of the Polish "October", was shut down. Peaceful demonstrators at Warsaw Technical University were attacked by a new branch of the militia - ZOMO - armed with long truncheons. Gomułka blamed the protests on "hooligans" and declared that "autonomous organisations cannot usurp the right of the political centre". He promised Poland would not return to the pre-October situation, but also vowed to make no concessions to capitalism or the bourgeoisie. $^{21}$

Faced with domestic stagnation, Polish hopes for change turned to developments abroad. Most promising were discussions of "market-type reform" by Soviet and Hungarian economists from 1962 and the gradual emergence of a "Prague Spring". But this was also being watched by

17 P. Machcewicz, Polski rok 1956, Warszawa 1993 and second enlarged edition, Rebellious Satellite, Poland 1956, Stanford 2009.

${ }^{18}$ M. Kramer, The 'Malin Notes' on the Crises in Hungary and Poland, 1956, "Cold War International History Project Bulletin" (hereafter CWIHP) 1996-1997, Vol. 8/9 Winter.

${ }^{19}$ Document of Great Historical Significance, "Pravda" (editorial), 3 July 1956.

${ }^{20}$ Report of Gomutka (22 November 1956) [in:] Tajne dokumenty Biura Politycznego. PRL-ZSRR 1956-1970, ed. A. Paczkowski, Londyn 1998, pp. 19-30.

${ }^{21}$ Archiwum Akt Nowych (hereafter AAN), BIBS Information Bulletin (44) (secret) 10, October 1957, p. 6. 
Gomułka. He became particularly concerned when Dubček replaced Novotny (Party chief since Stalin's day) in early 1968.

\section{A. January-March}

Dubček reassured Soviet leaders that his plan was simply to make Czechoslovak socialism correspond more closely to political and economic conditions. Western parts of the country had been economically well-advanced before the war. While stating that victims of Stalinist repression should be rehabilitated, he deliberately avoided terms controversial within Soviet vocabulary. Instead of reformism or revisionism, he spoke of socialist renewal and revival. Nonetheless, he found Brezhnev and his colleagues obdurate: "In contrast to early post-revolutionary attitudes, late Stalinism was marked by a self-deceptive arrogance in relation to other countries." 22 His first meeting with Gomułka, in Ostrava (7 February 1968), was equally disappointing.

The Polish leader was now sixty-three. "I knew he had failed to meet the hopes of his early supporters. At the same time, I did not realise how adamantly he opposed reform; I only discovered this later." 23 In their six-hour conversation, Gomulka stressed geopolitics. "The international communist movement finds itself in a difficult situation. We may say the decisive role in this movement is that of the Soviet Union and the other countries of the Warsaw Pact. At the same time, these countries are beginning to sound a bit creaky (trzeszczec). This atmosphere spreads across the whole movement". Gomułka declared that Poles advocating "full sovereignty" were neglecting the role of the Soviet Union whose military power was the essential protector of Poland's national interest and the only guarantor of its western boundaries. Broadening the horizons to international communism, he stated: "We cannot agree with Castro's understanding of sovereignty as a means to attack the Soviet Union. Fidel Castro is leading Cuba to catastrophe. He is not a communist but a petty-bourgeois anarchist (...) Castro speaks in this way »We are seven million, you must feed us and we will make world revolution «."24

He concluded his lecture on a domestic note: "We want your Party to be strong. Your being in a good situation helps us. If your situation worsens, our rogue elements will rear their heads." Indeed, they already had: "We now have trouble with writers and students over the theatrical production of Driady" (Forefathers).

Mickiewicz's classic had been showing at the Great Theatre in Warsaw since the fiftieth anniversary of the Russian Revolution. It is not clear why its subject, Poland's struggle for freedom under the Russian partition, was thought suitable by the theatrical censorship, During the run, audience reactions to the anti-Russian passages steadily grew. This alarmed the authorities, who banned the play from 30 January 1968, which happened to coincide with a favourable notice in Pravda. The last performance was packed out. Interjections from the audience increased. As the curtain fell, Karol Modzelewski called out from

\footnotetext{
${ }^{22}$ Hope dies last. The Autobiography of Alexander Dubček, New York 1993, p. 134.

${ }^{23}$ Hope dies Last..., p. 135.

${ }^{24}$ AAN, 237/ XIA/33, pp. 278-80,
} 
the gallery "Independence without Censorship". Some three hundred moved out to the Mickiewicz statue nearby, festooning it with flowers and banners. This first street manifestation by students for more than a decade shocked the Party leadership.

Warsaw University students drew up a petition to the Sejm: "We, Warsaw youth, protest against the decision to ban performances of Adam Mickiewicz's Dziady at the Great Theatre in Warsaw. We protest against a policy cutting us off from the progressive traditions of the Polish nation". There was strong support, particularly in the Departments of Philosophy, History, Political Economy and in halls of residence. According to the secret police "Jan Litynski (5th year maths and physics) spear-headed the campaign". There were 400 signatures by 5 February. ${ }^{25}$ When presented to parliament on 16 February, it had 3,000.

Polish writers issued their own petition, calling for an emergency Plenum of the Writers' Union, which met in closed session on 29 February. The 400 present heard a defence of the ban from the Minister of Culture who argued that the audiences had exploited a tendentious production. Writers responded by attacking on the Party's cultural policy. The sharpest was from the veteran Antoni Słonimski. He declared that little was left of the achievements of October 1956: "Writers censor themselves, then they are censored by editors and publishers." Censorship was not merely an Office, it was ubiquitous. Polish leaders had carried out the first stages of deStalinisation, restoring the rule of law, but these were now distant memories. However, there were encouraging signs abroad. "Democratic and genuine humanism is reaching us from our colleagues in Czechoslovakia. We watch with hope the activities of our Czechoslovak neighbours". ${ }^{26}$ A secret Party document on "excesses at Warsaw University" (10 March) reported that, alongside anti-government slogans, came the chant "Poland awaits her own Dubček." ${ }^{27}$ Such solidarity was reciprocated.

When an anti-Semitic pogrom by one faction of the Party leadership started to force thousands of Poles into emigration, ${ }^{28}$ the Polish ambassador in Prague received dozens of protest letters. They condemned "anti-Semitic propaganda unleashed in the Polish press, radio and TV" 29 and defended professors sacked from Warsaw University. These included the philosopher Leszek Kołakowski, sociologists Zygmunt Bauman and Maria Hirszowicz and political economist Włodzimierz Brus, all of whom gained posts at British universities. Addressing the Institute of International Politics in Prague, the American academic Zbigniew Brzeziński referred to recent Polish pogroms as "social fascism rather than communism". He noted that parts of the Polish political elite had responded to legitimate social aspirations with anti-Semitism. They were anti-intellectual,

\footnotetext{
${ }^{25}$ AAN, 237/XVI/586, "Wydarzenia marcowe", 6 February 1968.

${ }^{26}$ AAN, 237/XVIII/319, “Walne zebranie Oddziału Warszawskiego Związku Literatów Polskich (29.11.1968)”, pp. 43-45.

${ }^{27}$ AAN, 237/VII Informacja nr.9/A/4346, "Odgłosy na temat ekscesów na Uniwersytecie Warszawskim (10 March 1968)".

${ }^{28}$ D. Stola, Kampania antysyjonistyczna w Polsce, 1967-1968, Warszawa 2000.

${ }^{29}$ M. Górny, Wydarzenia marcowe w opinii czechostowackiej [in:] Marzec 1968. Trzydżeśsi lat później, tom 1 Referaty, Warszawa 1998, pp. $210-211$
} 
primitive and chauvinistic. ${ }^{30}$ Writers in Prague called for greater openness. Communist Party members also called for the abolition of preventive political censorship, singling out the heavyhanded treatment of the Writers' Union weekly Literarny noviny. ${ }^{31}$

Andropov, former ambassador to Budapest in 1956 and now head of the KGB, told the Soviet Politburo (15 March) that recent events in Czechoslovakia "are very reminiscent of what happened in Hungary". Brezhnev concurred and immediately telephoned Dubček to express concern about the "emergence of patently anti-socialist forces". In none too subtle language, he told the Czechoslovak leader that unless he moved rapidly to suppress "anti-socialist elements" "the Hungarian events of 1956 might soon be repeated." 32 In his first public comments on the "March events", after eleven days of silence, Gomułka extended his critique to "imperialist reactionaries and enemies of socialism" allegedly at work in Czechoslovakia. ${ }^{33}$ No evidence was offered to support this assertion.

Gomułka broadened his critique at a Dresden summit of the Warsaw Pact (23-25 March). "Why shouldn't we draw conclusions from Poland's experience in 1956? Why not draw conclusions from what took place in Hungary? They all began in the same way comrades. In our country and in Hungary it all began with the writers. It started with the Petofi Circle, and with us the same. Intellectu- als have been acting like this since 1956. This time it was again the writers. And in your country it also started with the intellectuals. Let us look at the situation correctly, as it happened. In your country it is also coming from there. And it didn't just start today. Later it grows into something larger." Pursuing the parallel, he added: "I don't want to remind you comrades of the student events in our country, because I already talked about this at length to Warsaw Party aktyw and analysed at length. Czechoslovak comrades, I think this fits your situation $90 \%$. The more you look at it, the more it looks the same. It all starts with the arts. Under the flag of defending culture and defending freedom, under this mask, the enemy, the counter-revolution, foreign intelligence works. They want to stir people up and achieve their goals this way." 34

Dubček noted that his harshest critic was Gomułka, with Ulbricht only slightly less arrogant. Although Brezhnev "put on the face of a worried parent", he was equally stinging in what he said. ${ }^{35}$

The Dresden communiqué made wider reference to "questions of European security". West German Ostpolitik was described as an imperialist attempt to subvert "the interests of the German Democratic Republic and other socialist states." ${ }^{36}$ According to a report from Bavaria, Czechoslovak border guards had taken down a series of barbed wire and electric fences on the frontier with Western Germany. ${ }^{37}$ Despite

\footnotetext{
${ }^{30}$ M. Górny, Wydarz̧enia marcowe w..., p. 217 (speech of 14 June 1968).

31 “Czechoslovak New Agency", 14 March 1968 [in:] Winter in Prague. Documents on Crechoslovak Communism in Crisis, ed.

R. Remington, Cambridge 1969, p. 54.

${ }^{32}$ M. Kramer, The Kremlin, the... p. 304.

${ }^{33}$ Gomułka's speech of 19 March was reprinted in Pravda three days later.

${ }^{34}$ AAN, KC PZPR, tom 1, paczka 298.

${ }^{35}$ Hope Dies Last..., p. 141.

${ }^{36}$ Dresden Communiqué, "Pravda" 25 March 1968.

${ }^{37}$ K. Dawisha, The Kremlin and the Prague Spring, Berkeley 1984, p. 53.
} 
these ominous developments, the communiqué expressed confidence that 'the working-class and all the working people of the CSR will ensure the further development of socialist construction in the country.' In response, Czechoslovak writers told their leadership: "The Dresden communiqué has made clear to us that you must resist pressures based on doubts about our internal measures... You should not forget that your primary responsibility is to the people of this country". ${ }^{38}$ On the same day, the Polish Consul-General in Ostrava reported a demonstration "in support of Polish students and professors", crying "Long Live Democracy" and "We wish you a Dubček". The crowd of several hundred included local students and even school-children. ${ }^{39}$

\section{B. April- July}

The Czechoslovak Communist Party unveiled its "Action Programme" on 5 April. Rejecting the Stalinist thesis of antagonistic classes - which "no longer existed" - they proposed "a frank exchange of views and democratisation of the whole social and economic system." ${ }^{40}$ A special Plenum in Moscow (9 April) discussed the strategic implications. It concluded that Soviet security, and that of the whole bloc, was now threatened by "imperialist subversion." Dawisha explains this widening agenda in terms of Soviet high politics: "If Czechoslovakia became the 'weak link' in the Warsaw Pact,
East Europeans and, more importantly, the Soviet defence establishment could legitimately enter the political debate over the reform movement." ${ }^{, 41}$

Gomułka told the Soviet Ambassador to Warsaw (16 April): “The process whereby socialist Czechoslovakia will be transformed into a bourgeois republic has already begun". Liquidation of democratic centralism was granting leeway for bourgeois expression, as was the formation of non-communist trade unions. Such "counterrevolutionary plans" being concocted in Prague were "having an increasingly negative effect on Poland. " ${ }^{\prime 4}$ He called for immediate intervention.

When the Warsaw Pact chief, Marshal Yakubovsky, visited Poland three days later Gomułka claimed "counter-revolutionary forces are trying to change the status of Czechoslovakia in the direction of bourgeois democracy." He cited the new constitution and electoral regulations, the demand for an extraordinary Party Congress, the "destabilising" political ambitions of other parties using the slogan of "legal opposition", and moves amongst communists to reactivate a social-democratic party. All this had implications abroad: "Our interests are without doubt linked to the situation in Czechoslovakia. Disorganisation of their army practically opens the frontier with the German Federal Republic.” Even minor disturbances in the German Democratic Republic could have untold consequences. It was "essential to preserve the Warsaw Pact through the Russian army in Czechoslovakia." ${ }^{43}$

\footnotetext{
${ }^{38}$ Open Letter, “Literarni listy” (Prague) 28 March 1968, (134 signatories).

${ }^{39}$ M. Górny, Wydarzenia marcowe w..., p. 212.

${ }^{40}$ Winter in Prague..., pp. 88-137.

${ }^{41}$ K. Dawisha, The Kremlin and..., pp. 56-61.

${ }^{42}$ Cable to Moscow from Soviet Ambassador to Warsaw Averki Aristov, 16 April 1968 [in:] The Prague Spring 1968, ed. J. Navratil, Budapest 1998, pp. 103-104.

${ }^{43}$ L. Pajorek, Polska a ,praska wiosna”. Udziat Wojska Polskiego w interwencji z̧brojnej w Czechostowacji w 1968 roku, Warszawa 1998 , p. 96.
} 
Pravda published a new critique of the Prague Spring (25 April). It stated that bourgeois notions of "freedom" were being mobilised to undermine the "achievements of working people." To oppose the Party's "leading role" was undermine the foundations of a socialist society. "There is no freedom for criminals, for propagandists of war and racism, for counter-revolutionaries". ${ }^{4}$ Here, in embryo, was the Brezhnev Doctrine.

A series of Polish diplomatic protests from mid-March about the unsettling effects of the "Prague Spring" culminated in a formal demarché on 6 May. This complained of "malicious and inimical commentary" on Poland in the - now uncensored - Czechoslovak press. ${ }^{45}$ At the same time, the Polish Politburo ordered the Foreign Ministry and Press Bureau of the Central Committee to prepare a paper for the Party aktyw on the "situation in Czechoslovakia." ${ }^{46}$ The working plan for this document was to focus on "revisionist right-wing views" which had allegedly taken hold of the Czechoslovak Communist Party. ${ }^{47}$ Gomułka elaborated these themes at a Moscow summit (8 May).

When the Hungarian leader dismissed the Czechoslovak "Action Programme" as a "big zero", he interrupted for clarification. Dissatisfied with Kadar's reply, Gomułka retorted "What does all this mean? It means equality for all existing ideologies; it means the legalisation of bourgeois ideology. And that is not just to be found in some programme. It exists in prac- tice in Czechoslovakia today. That same »Action Programme says that this year there will be constitutional guarantees of free assembly and opportunities to create voluntary social organisations conforming to the interests and needs of different strata of the population." ${ }^{38}$ The Polish hero of October 1956 now found the prospect of pluralism appalling.

The same thesis was advanced by Soviet media. Izvestiya condemned the bourgeois idea of "non-interference" by a communist or workers' party in a country's political, economic and ideological life. Such suggestions were made "under the artful slogans of »democratisation« or »liberalisation « of public life in the socialist countries." Recent US spokesmen, including Averell Harriman, who had negotiated the nuclear test ban treaty of 1963, indicated that "liberalisation" was in US interests insofar as it undermined communism in central and southeast Europe. ${ }^{49}$

Gomułka expressed further concerns to the Soviet Ambassador (22 May). Ceausescu and Tito had invited Dubček to visit their countries. Dubček himself had suggested that Poland and Czechoslovakia, together with Romania and Yugoslavia, could present a reformist counterweight to the Soviet Union. Gomułka had been horrified by this suggestion. "In comrade Gomułka's opinion, these three countries are united by their attraction to the West. Their common wish is to leave the socialist camp and to set up something in the nature of an unofficial alliance that

\footnotetext{
${ }^{44}$ S. Kovalev, Marxism and the Contemporary Ideological Struggle, "Pravda" 25 April 1968

${ }^{45}$ AAN, 237/X1A, pp. 327-330.

${ }^{46}$ Ibidem, pp. 331-334.

${ }^{47}$ Ibidem, p. 342.

${ }^{48}$ The Prague Spring..., pp. 138-139.

${ }^{49}$ V. Stepanov, The Leading Force in the Construction of Communism, "Izvestiya" 11 May 1968.
} 
might be formed among them". ${ }^{50}$ There is an echo here of the Ostrava meeting (7 February) when Dubček had suggested that Poland, Hungary, Czechoslovakia and Romania could jointly constitute a "Warsaw Four."51

The strategic importance of Czechoslovakia had been increasing for some time. One aspect of détente in Europe was a fundamental reappraisal of West German attitudes to the East European states: Ostpolitik..52 (We shall discuss this further in Section 2). But Moscow was determined to prevent a re-opening of the "German question". Following the establishment of diplomatic relations between West Germany and Romania in early 1967, Soviet leaders had summoned European communist parties to a conference at Karlovy Vary in Czechoslovakia and told them that none could follow suit. Moscow was now focussing on the "northern tier" of the Warsaw Pact: Poland, East Germany and Czechoslovakia, which had now become one of the most significant members the Eastern bloc. ${ }^{53}$ The new analysis was spelt out to the Czechoslovak leadership at a bi-lateral summit in Moscow (4 May).

According to Bil'ak, the most conservative member of the Czechoslovak delegation, the Soviets "begged us not to forget that the Western boundaries of the CSSR were at the same time the boundaries of the socialist camp". Emphasising the "sacrifices" Soviet leaders had made in establishing socialism in Czechoslovakia, they stated "under no circumstances would it be permitted for events to develop in such as way that sooner or later socialism would be liquidated in Czechoslovakia". This had become a concern of "international socialism as a whole". Bil'ak later summarised the Soviet position as saying the loss of Czechoslovakia to socialism would annul the results of the second world war. "They could not permit this even at the cost of a third world war." 54

Soviet leaders formed a high-level "Commission on the Czechoslovak Question" (23 May). Members included the chief ideologue Mikhail Suslov - who was again a key figure in the Polish crisis of 1980-1981- and Ukrainian Party leader Petro Shelest, who feared contamination from Czechoslovakia in his domain. As Kramer notes, rather than delegating and getting bogged down in lower-level bureaucratic manoeuvring, "the CPSU Politburo, led by Brezhnev, exercised tight control over Soviet policy" The Commission kept a daily watch over Czechoslovak developments and reported to Brezhnev directly. ${ }^{55}$

Preparations to invade Czechoslovakia had begun on 5 April, under the code-name "Operation Danube". The Soviet Defence Council (6 May) decided to send a high-level mission and to use large-scale military manoeuvres as a prelude to any future invasion. ${ }^{56}$ Warsaw Pact staff exercises began on 20 June.

\footnotetext{
${ }^{50}$ Cable from the Soviet Ambassador in Warsaw, 22 May 1968 [in:] The Prague Spring..., p. 147.

${ }^{51}$ Alexander Dubcek's Recollections of the Crisis, 10 August 1990 [in:] The Prague Spring..., p. 306.

${ }^{52}$ Recepcja Ostpolitik w RFN iw krajach bloku komunistycznego: Polska, ZSRR, NRD, Czechostowacja, Wegry, eds. J. Fiszer, J. Holzer, Warszawa 2004.

${ }^{53} \mathrm{Ph}$. Windsor and A. Roberts, Czechoslovakia 1968. Reform, Repression and Resistance, London 1969, p. 8.

${ }^{54}$ K. Dawisha, The Kremlin and..., pp. 72-77.

${ }^{55}$ M. Kramer, The Kremlin, the..., pp. 310-312.

${ }^{56}$ Ibidem, pp. 318-319.
} 
While large contingents of Red Army troops manoeuvred in Czechoslovakia, the Prague government abolished prior censorship, leaving responsibility to editors for what they published. Most of the press carried Ludvik Vaculik's extraordinary Two Thousand Words Manifesto (27 June.) This declared support for democratic reforms and also advocated resistance to Soviet pressures. "There has been great alarm recently over the prospect of foreign forces interfering in our internal development. Faced with whatever superior forces may confront us, all we can do is stick to our positions, behave decently and start nothing ourselves. We can show our Government that we will stand by it, with weapons if need be, (italics added) if it will do what we give it a mandate to do, and we can assure our allies that we will observe our alliance, friendship and trade agreements." 57

Philip Windsor regards this as a turningpoint in the Czechoslovak crisis. "To call on the government to move faster, to declare a willingness to resort to arms, at a time when Warsaw Pact forces were entrenching themselves in the country, was bound to polarize the extremes which the government had sought to avoid and had almost succeeded in avoiding at every turn hitherto: a polarisation between the internal demands of the Czechoslovak peoples and the external demands of Czechoslovakia's allies." ${ }^{58}$ The response from Moscow was immediate and unambiguous. Foreign Minister Gromyko issued a strong condemnation of imperialism in general and Ostpolitik in particular (28 June). Though not mentioning Czechoslovakia by name, he also delivered a strong warning to Soviet allies: “To defend the gains and cohesion of states belonging to our socialist commonwealth is our sacred duty, to which our country will be loyal despite all trials...Those who hope to break even one link in the socialist commonwealth are planning in vain." 59

Though military manoeuvres were scheduled to end on 2 July, Soviet troops remained in Czechoslovakia in considerable numbers. The threat of force was thus unambiguous. However, Moscow went to great lengths to reassure the United States and its Western allies that such an intervention was solely an "internal matter" within the Soviet bloc. They also implied that the Soviet Union would not act unilaterally, as in 1956, but with participation of other members of the Warsaw Pact.

Gomułka was most willing to take part. According to notes of his speech to the Polish Politburo (5 July), "I told Brezhnev that military intervention is necessary, but he replied that the matter is still open". He said there was still a "paper" phase: letters, conferences and so on. Yet Gomulka saw time as of the essence. The Czechoslovak Party was planning an extraordinary Congress for September at which democratic centralism would be eliminated. Under the guise of social democracy, the country would become a bourgeois republic. It was therefore necessary to "organise an opposition" of loyal Party members (Indra, Bil'ak and others) to prevent Czechoslovakia "leaving our camp". Before the

\footnotetext{
${ }^{57}$ L. Vaculik, 2,000 words to Workers, Farmers, Scientists, Artists, and Everyone, "Literarny listy" 27 June 1968.

${ }^{58} \mathrm{Ph}$. Windsor and A. Roberts, Czechoslovakia 1968. Reform..., p. 50.

${ }^{59}$ A. Gromyko, On the International Position and Foreign Policy of the Soviet Union, "Pravda" 28 June 1968.
} 
situation became even more complicated it was necessary to say to Moscow: "We will move in with our army, because our security is involved too. To Hell with Sovereignty!"

Moscow reminded Bonn (5 July) of the "enemies states" articles in the UN Charter. Action could be taken without Security Council approval against "any state which during the Second World War has been an enemy of any signatory of the present Charter" (Article 53). Article 107 adds: "nothing in the Charter shall invalidate or preclude action, in relation to any state which during the Second World War has been an enemy of any signatory to the present Charter". This inflammatory intervention made international diplomacy following the August invasion even more complex.

Poland's Central Committee Plenum (8-9 July) was principally focussed on the "March Events". But theses adopted for the next Party Congress denounced West Germany and condemned "revisionism" as "the main ally of imperialism". While conceding that it was the sovereign right of each Party to determine its own policies, they also declared this did not mean that "each Party and each socialist country can establish its policy in international matters, disregarding the voluntarily-accepted alliance concepts, as well as the opinions and policies of other parties and socialist states". ${ }^{61}$

Pravda asserted (1 July) that "champions of counter-revolution" were undermining "the bases of socialism" in Czechoslovakia. Unlike the "frenzied attacks launched by counter-revolutionary elements in Hungary in 1956", they were proceeding by stealth. These "ever more cunning and insidious" tactics - fully endorsed by their Western backers - recognised that any more overt revolution would be met by a Soviet military response. ${ }^{62}$

When invited to a Warsaw conference, Dubček realised he could not reject Brezhnev's summons out of hand. Instead, he suggested it be attended "by all European socialist countries, which would include Romania and Yugoslavia"63. Since Romania would not attend, and Yugoslavia was non-aligned, this was clearly a delaying tactic. While Prague prevaricated, the other Five Pact members met in Warsaw (July 14). In a private discussion beforehand, Gomułka told Brezhnev not to be "deceived" or "hoodwinked" by Dubček. A military response to the "Prague Spring" was now unavoidable: anything less would be an "empty gesture". ${ }^{64}$

Ulbricht was equally vehement: "The Czech plan for counter-revolution is clear. We cannot have any further doubt about this. The counterrevolutionaries want to prepare the (September) Congress to eliminate Marxism-Leninism. The Two Thousand Words is unambiguously counterrevolutionary. Then they will hold multi-party elections and try to annihilate the (communist) Party, and then want to change the constitution. Responding to Hungarian hesitations, he

\footnotetext{
${ }^{60}$ J. Eisler, Aneks 3, Notatka posiedžnia Biura Politycznego 5 lipca 1968 r. [in:] Wokót praskiej wiosny. Polska i Cžechosłowacja w 1968 roku, ed. L. Kamiński, Warszawa 2004, pp. 190-192.

61 “Trybuna ludu” 13 July 1968.

${ }^{62}$ I. Aleksandrov, Attack on the Socialist Foundations of Socialism of Czechoslovakia, "Pravda" 11 July 1968.

${ }^{63}$ A. Dubček, Hope dies last..., p. 162.

${ }^{64}$ M. Kramer, The Kremlin, the..., pp. 335-36.
} 
declared: I don't know, comrade Kadar, why you can't see this. Don't you see that the next blow from imperialism will fall on Hungary? We can see that imperialist circles are now focused on the Hungarian intelligentsia". ${ }^{65}$

In a further dig, at Gomulka, he referred to the recent lecture by Brzezinski in Prague, and promised to send him a transcript. ${ }^{66}$ Gomułka had frequently castigated Brzezinski - whose works he probably never read - as an "imperialist running-dog" and one of Poland's worst enemies.67

The Bulgarian leader Zhivkov was also categorical: "We cannot now rely on internal forces in Czechoslovakia. They will not have sufficient forces to carry out what we will say in our (Warsaw) Letter. Only by using the forces of the Warsaw Pact can we change the situation." ${ }^{\circ 8}$ Brezhnev's summing-up conceded that Czechoslovakia was in the grip of "counter-revolution". While not yet committing to military intervention, he recognised that "imperialist circles" were interested in Czechoslovakia as a country "located in the centre of Europe and of the socialist camp".

While abjuring "any intention to interfere in affairs that are purely internal to your Party and state", the Warsaw Letter (15 July) stated "hostile forces are pushing your country from the socialist path and creating the threat that
Czechoslovakia may break away from the socialist commonwealth. This is no longer your affair alone... It is the common concern of our countries, united in the Warsaw Pact, to safeguard their independence, preserve peace and security in Europe and to erect an insurmountable barrier to the schemes of imperialist aggressors and revanchists". ${ }^{69}$ The Letter set out two essential elements of the Brezhnev Doctrine (1) the subordination of national interests to those of international communist movement as defined in Moscow (not Bucharest or Beijing) and (2) not only the right but the duty of socialist states to come to their defence wherever it might be threatened. ${ }^{70}$ It was a carte blanche for interventionism.

The Soviet Politburo now finalised their policy for handling the Czechoslovak crisis. They unanimously approved plans for an invasion and "authorised comrade Grechko (Defence Minister) to take measures carry out those plans in an expeditious manner'. But they also formulated a negotiating strategy for last-ditch bi-lateral talks. ${ }^{71}$

When these began, in the border town of Čierna nad Tisou (29 July), Brezhnev gave a definitive account of his Doctrine. "The fate of Czechoslovakia as a socialist state is not purely an internal affair of the Czechoslovak Communist Party (CPCz). This is the common affair of the whole commonwealth of socialist countries

\footnotetext{
${ }^{65}$ AAN, KC PZPR, tom 24, paczka 193.

${ }^{66}$ Ibidem.

${ }^{67}$ E. Weit, Eyewitness. The Autobiography of Gomutka's Interpreter, London 1973, pp. 203-204.

${ }^{68}$ AAN, KC PZPR, tom 24, paczka 193.

${ }^{69}$ The Prague Spring..., pp. 234-328.

${ }^{70}$ K. Dawisha, The Kremlin and..., p. 212.

${ }^{71}$ M. Kramer, The Kremlin, the..., p. 338.

${ }^{72}$ The Prague Spring..., pp. 286-289.
} 
and of the entire communist movement. That is why the CPSU CC believes it has an international duty to see to it that all measures lead to the strengthening of the $\mathrm{CPC} z$, to the protection and strengthening of socialism in the CSRR, and to the defence of Czechoslovakia from imperialist conspiracies. This, I repeat, is our international duty, it is the international duty of all fraternal parties, and we would cease to be communists if we refused to discharge it" ${ }^{72}$

Kosygin was even more categorical. "We regard the Warsaw Pact as a treaty that binds our parties and our peoples together in the face of imperialism Manoeuvres are now beginning. What are we to think? Where is your border and where is our border, and is there a difference between your borders and ours? Comrade Dubček and Comrade Černík (Prime Minister), you cannot deny that we have only one border - the one that abuts the West and separates us from the capitalist countries" ${ }^{73}$

\section{August}

Multilateral talks were held in Bratislava (2 August). Before setting out, Gomulka told the Czechoslovak Ambassador that no political "solution" could be successful without a change of leadership in Prague. In his view, the current team was liquidating socialism. Moreover, their "democratisation process" was "causing dif- ficulties" amongst various sections of the Polish public, "especially the clergy." 74 As Zdeněk Mlynár observed at the talks, "Walter Ulbricht and Wladysław Gomułka were hostile, vain, and senile old men. It was quite clear that they had no interest in understanding the developmental problems of their own countries, let alone of their neighbours. Both of them radiated a selfsatisfied intoxication with their own power." 75 Harmony was not helped by the assertion of Shelest that Czechoslovakia was trying to wrest the Carpatho-Ukraine from the Soviet Union or by his open anti-Semitism. ${ }^{76}$

The day's task was to formulate a joint statement. The draft stated "Supporting, consolidating, and defending these gains (of socialism), achieved through the heroic efforts and selfsacrificing labour of each nation, is the common international duty (italics added) of all the socialist countries". It affirmed: "Such was the unanimous opinion of all participants at the meeting." Mlynár suggested an additional clause: "While respecting the sovereignty and national independence of each country". But Brezhnev immediately interjected that inserting a dash into the document at that point would "violate the Russian language" 77 and lead to repetition. He pointed to a later paragraph which declared: "The participants in the conference expressed a firm desire to do everything they can to improve the all-round cooperation of their

\footnotetext{
${ }^{72}$ The Prague Spring..., pp. 286-289.

${ }^{73}$ Ibidem, p. 296.

${ }^{74}$ Ibidem, p. 319.

${ }^{75}$ Z. Mlynár̆, Night Frost in Prague. The End of Humane Socialism, London 1980, p. 155.

${ }^{76}$ Ibidem, p. 152.

${ }^{77}$ Ibidem, pp. $154-155$.

${ }^{78}$ Statement by the Communist and Workers' Parties of Socialist Countries, "Pravda” 4 August 1968.
} 
countries on the basis of the principles of equality, respect for sovereignty and national independence, territorial integrity, fraternal mutual assistance, and solidarity." Although overruled, Mlynář did manage to insert a qualifier: "each fraternal party decides all questions of further socialist development in a creative way, taking into account specific national features and conditions." However, the crucial sentence "non-interference in internal affairs"- which would have fully satisfied Dubček's domestic agenda - does not appear in the Declaration. ${ }^{78}$

Following this apparent unanimity, East-West relations relaxed and the Soviet ruling troika and their East European counter-parts, left for their summer holidays. Dubček and Mlynář both viewed Brezhnev as holding open the possibility of non-intervention, provided certain steps were taken: re-imposing censorship, removing factions in political life and restoring "democratic centralism." Thus its prime movers were now expected to end the "Prague Spring". However, the Soviet Politburo voted unanimously (17 August) to "provide assistance and support to the Communist Party and people of Czechoslovakia through the use of armed forces." ${ }^{\text {79 }}$ Brezhnev informed his Polish, East German and Bulgarian counter-parts at a meeting in Moscow next day.

The great bulk of the invading forces 350.000-400.000 - were Soviet. The Poles, Hungarians and Bulgarians provided a further 70.000-80.000 and East Germans a token liaison unit. They all invaded on the night of 2021 August, ostensibly "by invitation" of certain
Czechoslovak politicians. The Soviet news agency (TASS) was "authorised to state that the party and government leaders of the Czechoslovak Socialist Republic have asked the Soviet Union and other allied states to render the fraternal Czechoslovak people assistance, including assistance with armed forces." The request was to eliminate the "threat emanating from the counter-revolutionary forces which have entered into a collusion with foreign forces hostile to socialism".

Transported to Moscow, Brezhnev told Alexander Dubček he was no longer reliable. Though he had long defended "our Sasha", that stage was now over. Instead, he launched into a long account of Soviet sacrifices in the Second World War. The outcome was Soviet security, guaranteed by the post-war division of Europe and specifically the fact that Czechoslovakia was linked to the Soviet Union "forever". Hence the western borders of Czechoslovakia were the common borders of the "socialist camp". "Today it might seem impossible for you to accept it all. But look at Gomułka. In 1956, he too was against Soviet military assistance, just as you are. But if I were to tell him today that I was about to withdraw the Soviet army from Poland, Gomułka would jump into a special plane and fly here to plead with me not to do it". Mlynáŕ noted that Brezhnev did not use technical terms like sovereignty or national independence, or any official clichés about "mutual interests of the socialist countries". There was only one concern: Soviet soldiers had fought their way to the Elbe and "that is where our real Western borders are today." 80

\footnotetext{
78 Statement by the Communist and Workers' Parties of Socialist Countries, "Pravda" 4 August 1968.

${ }^{79}$ M. Kramer, The Kremlin, the..., p. 347.

${ }^{80}$ Z. Mlynár, Night Frost in..., pp. 237-242.
} 
Five-power talks were held in Moscow (2426 August). Brezhnev reported his meetings with Dubček and Černík at which he had explained that they must act in the spirit of the Cierna and Bratislava accords. "The Czechoslovak comrades must understand that it they fail to do this there will be bloodshed in Czechoslovakia. In such a situation the allied troops cannot retreat even a single step." Kosygin said "We are now in a position of strength. At Čierna we had an Agreement, but no strength to back it up". ${ }^{81}$

Gomułka was adamant. "Do we want to capitulate or not? If Dubček and Černík go back to Prague, the counter-revolution will go further." The Czechoslovak Party is "re-forming as a social democratic party which will then move on to counter-revolution." The balance of forces in Europe was also shifting. "Czechoslovakia is effectively outside the Warsaw Pact and so it the Czechoslovak army. We have only the territory of Czechoslovakia, but no majority of the population, party or military. What's really happening there is a counter-revolution, led by the intelligentsia. A majority of the population remains passive. Communists fear to show their heads. The situation is worse than Hungary in 1956." 82

Soviet and Czechoslovak leaders signed the Moscow Protocol (26 August). Paragraph One referred back to the documents agreed at Čierna nad Tisou and Bratislava, "They reaffirmed their loyalty to the pledge by the socialist countries to support, strengthen, and defend the gains of socialism and to wage an irreconcilable struggle against counterrevolutionary forces, a struggle that is the common international duty (italics added) of all socialist countries". Soviet troops would remain in Czechoslovakia until "the threat to the security of the countries of the socialist commonwealth had been eliminated". No deadline for withdrawal was given nor any procedure to determine when security had been achieved." Czechoslovak agreed to withdraw its earlier request for the UN Security Council to debate "The Matter of the Situation in Czechoslovakia."83

The Polish Party held emergency meetings (21 August) to inform the rank-and-file about the five-power invasion. A Central Committee letter to all members criticised the Czechoslovak media for attempting to present the Bratislava Declaration as a "victory" and as "rescuing sovereignty". Their press and publications "undermined the Warsaw Pact and the principles of internationalism, unity and solidarity of the socialist countries". ${ }^{84}$

There were strong reactions from some Czechoslovaks on Polish soil. Reports from Krakow describe the 'great indignation' of the Slovak population in Nowy Sącz, Nowy Targ and Zakopane towards the Polish population. They threw stones, attacked public and tourist buses and addressed "various abusive epithets (swine etc)." There was a flurry of "inimical" pamphlets, posters and graffiti:

\footnotetext{
${ }^{81}$ AAN, KC PZPR, p. 119, tom 54, Protokót ze spotkania partyjno-rzqdowych delegacji Butgarii, NRD, Polski, Wegier i ZSSR (Moskwa 24-26 sierpnia 1968 r.).

${ }^{82}$ AAN, KC PZPR, tom 54, p. 119.

${ }^{83}$ The Prague Spring..., pp. 477-480.

${ }^{84}$ AAN, 237/VII/5790 t. 1, KC PZPR: Do wszystkich organizacji partyjnych, 21 August 1968, pp. 269-272.
} 
- Long live Dubček and his party! We don’t want a repeat of September 1939 and the Hungarian events of twelve years ago. We condemn the military intervention in Czechoslovakia (Rabka)

- Gomułka has raised his hand against Czechoslovakia. For Your Freedom and Ours. The Soviets have occupied Czechoslovakia. You are not alone! (Brzeg)

- Brezhnev is an aggressor, a criminal. We demand the withdrawal of armies from Czechoslovakia (Opole). ${ }^{85}$

A group of fifty students met the Party secretary in Koszalin. They sharply criticised the Warsaw Pact invasion, stating that this breached the sovereignty of Czechoslovakia. ${ }^{86}$

Some Polish reactions were similarly sharp. Pamphlets collected by the security services stated:

- Communists are the imperialists against Czechoslovakia. We demand the release of Dubček. Communist imperialists: go home! (Poznań);

- USSR - aggressor. Long live Czechoslovakia. Long live Dubček. Brezhnev - Hitler (Konin);

- The road to socialism does not lead through Moscow (Gostyń);

- Disgrace! Down with aggression. Occupiers go home. Hitler-Brezhnev-GomułkaUlbricht-Kadar-Zhivkov (Zakopane, on the way to Morskie Oko). ${ }^{87}$
There were also workers' protests:

- Strike! Long Live a free Czechoslovakia.

Long Live Polish workers and students.

Down with strangling freedom (Wroclaw). ${ }^{88}$

But one should not over-estimate the general public reaction. Nor were intellectual responses more extensive, with honourable exceptions. Jerzy Andrzejewski published a critical Open Letter' in "Le Monde" (27 September). Bronislaw Geremek, Krystyna Kersten and other leading members of the Institute of History, Polish Academy of Sciences, returned their Party cards.

There was post-invasion disaffection amongst Polish soldiers stationed in northern Moravia. Many expressed surprise at the absence of American "imperialists" and West German "revanchists" against whom they had been told they were deployed. ${ }^{89}$ The East European units were soon withdrawn and they were not included in the bilateral Soviet-Czechoslovak "Treaty on the Temporary Presence of Soviet Forces in Czechoslovakia" (16 October 1968).

When Gomulka addressed the Central Committee (29 August) his theme was the need for unity in the Warsaw Pact. Though it had been ruptured long ago, with the departure of Yugoslavia (before the Pact was formed) and of Romania, the further loss of Czechoslovakia could not be contemplated. The Czechoslovaks had talked about "neutrality". "Could East Germany become neutral? It would be rapidly swallowed up by the German Federal Republic.” Then Poland

\footnotetext{
${ }^{85}$ AAN, 237/VII/5790 t. 1, Zachowanie obywateli czechostowackich na terenie Polski, 23 August 1968, p. 313-314.

${ }^{86}$ AAN, 237/VII/5790 t. 1, Niektóre fakty i wydarzenia na terenie wojewódz̨tw, 23 August 1968, p. 328.

${ }^{87}$ AAN, 237/VII/5790 t. 2, Przejawy wrogiej driałalności w kraju, 26 August 1968, pp 364-365.

${ }^{88}$ W. Suleja, Dolnoślaski Marzec '68. Anatomia protestu, Warszawa 2006, pp. 338-339.

${ }^{89}$ L. Kowalski, Kryptonim „Dunaj”: Udziat wojkk polskich w interwencji z̧brojnej w Cžechostowacji w 1968 roku, Warszawa 1992, pp. 180-191.
} 
would face an entirely new situation in Europe: "the rebirth of German with pre-war boundaries, the German Democratic Republic gobbled up by the Federal Republic, creating a mighty German state". 90 A "Letter to all Party Organisations" rehearsed these apocalyptic visions. ${ }^{91}$

Moscow had sent two messages to Washington immediately prior to the invasion. The first (18 August) invited President Johnson to Moscow, suggesting early October as a convenient date. ${ }^{92}$ Postinvasion, Brezhnev exclaimed to his Czechoslovak colleagues, now prisoners in the Kremlin: "What are you waiting for? Do you expect anything is going to happen to help you? No, there is going to be no war - you might as well take note of that. I had an enquiry sent to President Johnson asking him whether the US would respect the Yalta and Potsdam Agreements and on 18 August received his reply saying that as far as Czechoslovakia and Romania were concerned the US would unquestionably honour these Agreements. The case of Yugoslavia would be subject to negotiations".93 The second missive, from Premier Kosygin, proposed bi-lateral talks on strategic arms limitation and antiballistic missile defences to convene in Leningrad on 30 September. ${ }^{94}$ Both leaders agreed that a simultaneous announcement to confirm this would be made in Moscow and Washington on 21 August.
At a hastily-convened Cabinet (22 August), the President stated, somewhat defensively, "We did not assume there would be no intervention." At a previous meeting (10 August), the CIA had reported the Czechoslovak crisis as "eased, not over". ${ }^{95}$ Walt Rostow had told the President that the chances of an invasion had increased..$^{96}$ A carefully-constructed communiqué stated that the US had no military commitment to intervene in the crisis, nor that it would be in Czechoslovak interests for them to do so. Dean Rusk added that "if there were (US) military intervention there would be a world war". US-Soviet relations were 'in transition', and the President would go anywhere, at any time, in the interests of peace. ${ }^{97}$

Dubček recalled that Soviet accusation of "imperialist interference" was purely a pretext for invasion. In the event, US forces were withdrawn 200 kilometres to the west. When visiting Congress much later, he was greeted with unanimous expressions of relief: "You helped us out by not resisting militarily. Fortunately you kept a cool head. Any other course of action would have posed a danger, not only for you, but one which could have meant a catastrophe for all of Europe, and ultimately perhaps for the whole world." 98

Of greater geopolitical and strategic consequence was its impact on Sino-Soviet relations.

\footnotetext{
${ }^{90}$ AAN, 237/X1/367, t. 73, Speech to Central Committee, 29 August 1968, pp. 25-26.

${ }^{91}$ AAN, 237/X1/213, 3 September 1968.

${ }^{92}$ Lyndon B. Johnson Presidential Library, Austin, National Security Foundation (hereafter NSF), Files of Walt W. Rostow, Box 11, 19 August 1968.

${ }^{93}$ Reported by Z. Mlynár, August 1968 [in:] Communist Reformation, ed. G.R. Urban, London, 1979, p. 132; Z. Mlynář, Night Frost in..., p. 241.

${ }^{94}$ Lyndon B. Johnson Presidential Library, NSF Files of Walt W. Rostow, Box 15, 20 August 1968.

${ }^{95}$ Lyndon B. Johnson Presidential Library, Tom Johnson's Notes of Meetings, Box 3, Lyndon B. Johnson Presidential Library, Ranch Meeting, 10 August 1968.

${ }^{96}$ K. Dawisha, Interview with Walt Rostow [in:] idem, The Kremlin and..., p. 279.

${ }^{97}$ Lyndon B. Johnson Presidential Library, Cabinet, 22 August 1968.
} 
China called the invasion "a crime against the Czechoslovak people", but did not endorse the "Dubček clique". They considered Moscow and Prague to be rival 'revisionist, renegade cliques'. By seeking independence, Dubček's "clique" would have started a chain reaction ending the Soviet bloc in Eastern Europe. Moscow had intervened to prevent this. They were assisted by Washington in an unholy alliance to divide the globe into separate spheres. ${ }^{99}$ China increased its military deployment on the Soviet frontier, leading to a border guard confrontation in March 1969 on Chen-pao Island in the Ussuri river. It sought improved relations with the US to contain the expansion of the Soviet Union: their mutual 'main enemy.'100

The UN Security Council debated the invasion from 21-24 August. Despite Soviet attempts to deny discussion on the grounds that Czechoslovakia had "requested military assistance," a Western-backed Resolution condemned "armed intervention in the internal affairs" of Czechoslovakia as contrary to the Charter and called for immediate withdrawal of outside forces. ${ }^{101}$ Despite majority support, the Soviet veto prevented its adoption. The UN could thus do even less than during the invasion of $1956 .{ }^{102}$

\section{Consequences}

American notions of security doctrines were a hall-mark of the Cold War. Eisenhower's Doc- trine, (Middle East, 1957), included the pledge to "secure and protect Middle Eastern nations 'against overt armed aggression from any nation controlled by International Communism." The Kennedy Doctrine (Latin America, 1963) undertook "to come to the aid of any government requesting aid to prevent a takeover aligned to the policies of foreign communism... (we must) prevent the establishment of another Cuba in this hemisphere. Likewise, the Johnson Doctrine (Latin America,1964) declared »We must protect the Alliance against the efforts of communism to tear down all that were are building«. Finally, the Nixon Doctrine (Persian Gulf, Middle East, Vietnam, 1969) promises 'we shall provide a shield if any nuclear power threatens the freedom of a nation allied with us." 103 Soon after the Warsaw Pact invasion, US analysts announced a Brezhnev Doctrine, 1968 (Czechoslovakia). A seminal source was held to be a Pravda article Sovereignty and the International Obligations of Socialist Countries (26 September).

This admitted "it is impossible to ignore the allegations being heard in some places that the actions of the five socialist countries contradict the Marxist-Leninist principle of sovereignty and the right of nations to self-determination. Such arguments are untenable primarily because they are based on an abstract, non-class approach to the question of sovereignty and the right of nations to self-determination." A socialist state

\footnotetext{
${ }^{98}$ Interview of August 1990, The Prague Spring..., p. 307.

${ }^{99}$ Cited in: H.G. Skilling, Czechoslovakia's Interrupted Revolution, p. 750.

${ }^{100}$ N. Tucker, China under Siege: Escaping the Dangers of 1968 [in:] 1968: The World Transformed, eds. C. Fink, Ph. Gassert and D. Junker, Cambridge 1998, pp. 193-216.1

${ }^{101}$ H.G. Skilling, Czechoslovakia's Interrupted Revolution, Princeton 1976.

${ }^{102}$ C. Bekes, The 1956 Hungarian Revolution and World Politics, CWIHP Paper 16, Washington 1996.

${ }^{103}$ B. Loveman, No Higher Law:..., p. 317.
} 
had a wider duty to all other socialist countries and the entire Communist movement, to ignore which would be "shirking internationalist obligations." In a passage that could have come just as appropriately from Zhdanov's "Two Camps" speech, founding Cominform in 1947, Kovalev stressed "the general context of class struggle.. between the two antithetical social systems capitalism and socialism". Czechoslovakia's talk of "self-determination" was a cover for neutrality and separation which would result in NATO troops on Soviet borders and dismemberment of the 'socialist commonwealth'. Gomułka was quoted with approval for his metaphor: "If the enemy plants dynamite under our house, beneath the socialist commonwealth, our patriotic, nationalist, and internationalist duty is to prevent this by using all necessary means." 104

The notion of a Socialist Commonwealth had a strange semantic history. Coined in Poland in 1957, it attempted to express the view that Soviet relations with Eastern Europe could evolve along a similar path to that taken by what were now termed British Commonwealth countries. ${ }^{105}$ But whereas the British notion involved independence under a titular head of state, the Soviet Union used the word to denote dependence on and deference to Moscow. Under the Brezhnev Doctrine, not only Czechoslovakia, but also Romania and even Yugoslavia - despite non-alignment - could be liable to Soviet intervention. Instead of causing stability, the Doctrine aroused uncertainty, since analysis of what constituted a threat to "socialism" was monopolised by Moscow. Other Warsaw Pact leaders added angles of their own. Ulbricht railed against the notion of a "non-violent uprising" which he claimed had been concocted by "West German experts on counter-revolutionary activity" and exported to Czechoslovakia. They taught the Czechoslovaks that such an uprising did not take the form of a civil war but was to be carried out "in a civilised way, with good manners and even with the toleration of intimidated state organs." "106

"Limited sovereignty" was endorsed by Brezhnev at the Fifth Congress of the PZPR. He noted the Polish Party had always understood that socialist countries could find their own path to socialism according to the specifics of their national conditions. However, "when there is a threat to socialism in one country, threatening the security of the whole socialist commonwealth, this is no longer the problem of the country alone, but the responsibility of the socialist countries as a whole. Discharging their internationalist duty towards the fraternal peoples of Czechoslovakia, and defending their own socialist gains, the USSR and the other socialist states had to act decisively and they did act against the anti-socialist forces in Czechoslovakia.”107

As Loveman notes, "Like the American »No Transfer Principle« and the Monroe Doctrine, the Brezhnev Doctrine was based on an elastic notion of the sovereign right of »self-defence«."

\footnotetext{
${ }^{104}$ S. Kovalev, Sovereignty and the International Obligations of Socialist Countries, [in:] Winter in Prague. Documents on Czechoslovak Communism in Crisis, ed. R. Remington, Cambridge 1969, pp. 412-416.

${ }_{105} \mathrm{Ph}$. Windsor and A. Roberts, Czechoslovakia 1968. Reform..., p. 82, note 15.

${ }^{106}$ Ulbricht, speech of 12 October 1968, quoted by: ibidem, pp. 141-142.

${ }^{107}$ L.I. Brezhnev, V Zjazd PZPR. Stenogram. Warszawa 11-16.XI 1968 r., Warszawa 1969, pp. 292-303.
} 
Soviet justifications of the Doctrine "echoed the contorted rhetorical efforts by American policymakers between 1898 and 1933 to reconcile the sovereignty of Latin American nations with recurrent US interventionism". He wonders teasingly whether Brezhnev had a copy of Theodore Roosevelt's "Corollary to the Monroe Doctrine", simply altering one word: "Chronic wrongdoing, or an impotence which results in a general loosening of the ties of civilized (socialist) society", required "intervention by some civilised (socialist) nation." 108

Following the removal of Dubček and his team, the Husák leadership signed a Soviet-Czechoslovak Treaty of Friendship and Mutual Assistance (6 May 1970). The Preamble, and Articles 5 and 9, codified the principle outlined in the Bratislava Declaration according to which the defence of socialist achievements in the "joint internationalist duty of the socialist countries". New Prime Minister Štrougal told the Federal Assembly in Prague (28 May 1970) that "the so-called theory of limited sovereignty is an imperialist invention to inflame nationalist passions." He added, however, "the maintenance and defence of socialist achievements against diversion and counter-revolution does not and cannot signify a limitation of the sovereignty of a socialist state; on the contrary, they are the expression of that sovereignty." 109 Nonetheless, the five-power invasion faced widespread condemnation in the international communist movement.

The Romanian leader, who had declined to participate in the invasion, addressed his $\mathrm{Na}$ - tional Assembly on 23 August 1968. "Whom was this military intervention aimed at? Against the legal, leading bodies of the communist party and Czechoslovak state. Were these institutions threatening socialism in Czechoslovakia, its independence and sovereignty? ... Since when did the principles of socialist democracy, humanism and socialist relationships become »counterrevolutionary dangers «?" 110 Addressing a crowd of over 80.000 from the balcony of the Central Committee building, he shouted: "There is no justification, no acceptable reason to allow, even for a single moment, the idea of military intervention in the internal affairs of a fellow Socialist state we must stop the interference in the affairs of other countries or parties for good... We declare to everyone: the Romanian people will prevent any foreign forces from entering our territory." 111

Members of the Romanian Central Committee had been even more outspoken. On the day of the invasion, Manea Mănescu declared "What this Great Power (Russia) has done today is a repetition of methods and techniques employed in the past to threaten the existence of other countries and peoples. That is why I believe it is very good to take steps concerning the armed forces, and the founding of the workers' and patriotic guards, so that we can resist these threats. We owe this to the younger generation and to those generations to come. We have a duty to defend our territory, national independence, and sovereignty, without which we cannot exist as a people." 112 Vasile Vâlcu agreed: “The invasion

\footnotetext{
${ }^{108}$ B. Loveman, No Higher Law:..., pp. 254-255.

${ }^{109}$ F. Fejto, Epilogue [in:] idem, A History of the People's Democracies. Eastern Europe Since Stalin, London 1971, p. 330.

110 "Scinteia" 21 August 1968, [in:] Winter in Prague..., p. 358.

${ }^{111}$ M. Retegan, In the Shadow of the Prague Spring. Romanian Foreign Policy and the Crisis in Czechoslovakia, 1968, Portland 2000, pp. 188-189.

${ }^{112}$ Ibidem, p. 217.
} 
of Czechoslovakia is an extremely brutal action, a flagrant infringement of the independence and sovereignty of the country." He added a personal note: "I am an old militant, but I never thought that a Socialist country would ever invade another Socialist state, a people trying to build socialism. This is an invasion; I cannot find words to express my disapproval of this violent military occupation that could only have been done by Hitler's men."113

Tito condemned the invasion as a blow against communism and a challenge to his own defence policy, aimed exclusively against NATO intervention. But he rejected a US notion of Yugoslavia as a "grey zone" to be shielded by NATO. The Soviet media left unclear, perhaps deliberately, whether the Brezhnev Doctrine also applied to countries on the peripheries of the Warsaw Pact.

Moscow faced further sharp criticism from Western communists. The Spanish leader Santiago Carrillo considered the invasion of Czechoslovakia an "operation carried out with methods similar to those employed in the famous trials of 1936, which had been exposed at the Twentieth Congress of the CPSU, or similar to those used in the denunciation of Yugoslavia in 1948. Namely, a stark statement was made - in this case that Czechoslovakia was on the verge of falling into the hands of capitalists - and from that starting-point stories were concocted that were lightyears away from the truth." He concluded that this was "the straw that broke the camel's back and led our (Eurocommunist) parties to say: No. That kind of »internationalism « had come to an end as far as we were concerned." 114

The Soviet Politburo sent them explanatory missives. The first stressed the necessity to conduct the invasion since: "It had been established that the counter-revolutionary forces had a large quantity of munitions at their disposal. In the very first days, thousands of automatic rifles, hundreds of machine guns, and dozens of bazookas were discovered in various hiding-places. Mortars and other heavy weapons have been found". ${ }^{115}$ A longer dispatch informed Western communist parties that the decision to base Soviet troops on Czechoslovak soil was necessary for an indefinite period "to guarantee the security of the socialist camp in the light of the strengthening revanchist and neo-Nazi forces in West Germany." Accusations by some Western communists that this was an 'Occupation' were dismissed as a "total falsification of reality". Armed intervention "had no other objective than the consolidation of socialism in Czechoslovakia, the defence of its independence, and the protection of the common goals of world socialism." "116

Despite these alibis, the invasion was the landmark at which point most Western communists ceased to consider the Soviet Union as a model for their own development. To Anatoly Chernyaev it was "the beginning of the end of the communist movement as a meaningful European or even international forces."

\footnotetext{
${ }^{113}$ Ibidem, p. 218.

${ }^{114}$ S. Carrillo, 'Eurocommunism' and the State, London 1977, p. 132.

${ }^{115}$ RGANI, Fond 1, opis' 72, delo 201, 2 September 1968, pp. 31-40.

${ }^{116}$ RGANI, Fond 3, opis' 72, delo 214, 28 October 1968, pp. 55-78.
} 
The feeling was mutual. "The Brezhnev leadership lost interest in them, since they were no longer needed in the context of Realpolitik." ${ }^{117}$ Even so, Soviet ideologists still attempted to devise new meanings for the word "sovereignty."

Under the Warsaw Pact Charter (1955) members had undertaken to "abide by the principles of mutual respect for their independence and sovereignty, and non-interference in their internal affairs." But now Soviet theorists began to distinguish between "bourgeois" and "class-based" notions of sovereignty. Far from breaching Czechoslovak sovereignty, the invasion was said to have affirmed it by "defending Czechoslovakia's independence and sovereignty as a socialist state" against "the counter-revolutionary forces that would like to remove its sovereignty." "118 This was an attempted rejoinder to Romania's protest at the invasion: "This act represents a flagrant violation of the national sovereignty of a fraternal, socialist, free and independent state, of the principles on which relations between socialist countries are based, and of the unanimously recognised norms of international law." "119 The Russian and Romanian positions could hardly have been more divergent, yet in 1989 they were reversed. ${ }^{120}$

\section{Part Two: Ambivalence}

Former Foreign Minister Willy Brandt, installed as West German Chancellor in 1969, recognised that the road to Eastern Europe ran through Moscow. Meeting Soviet demands for security was a precondition for changing the pattern of international relations on the continent. The Moscow-Bonn Treaty (12 August 1970) gave "unconditional respect for the territorial integrity in the their present borders of all the countries of Europe." It did not grant the full legal recognition of East Germany on which Soviet leaders had originally insisted, but was the first official document in which the Federal Republic acknowledged the DDR existed. A separate diplomatic note to Moscow restated the West German goal of eventual German unity. ${ }^{121}$

The Warsaw-Bonn Treaty (7 December 1970) confirmed Poland's western frontier, the OderNeisse line, as permanent in perpetuity. This ended a long-standing diplomatic campaign. When Poland's Foreign Minister Rapacki had proposed a nuclear-free zone for Central Europe (2 October 1957), he told the United Nations 'NATO is judged by every Pole according to its policy towards Germany'. Now the bogey had been lifted. A speech by Cyrankiewicz at the signing ceremony declared the date might come

${ }^{117}$ A. Chernyaev, Byl li u Rossii shans? On poslednij, Moscow 2003, pp, 14-25,

118 A. Sovetov, The Contemporary Stage of the Struggle between Socialism and Imperialism [in:] Mezhdunarodnaya zhizn', Moscow November 1968.

${ }^{119}$ Official Rumanian Communique on the Military Occupation of Czechoslovakia, "Scinteia" 22 August 1968 [in:] Winter in Prague..., pp. 358-389.

${ }^{120}$ D. Petrescu, Legitimacy, Nation-Building and Closure: Meanings and Consequences of the Romanian August of 1968 [in:] The Prague Spring and the Warsaw Pact Invasion of Czechoslovakia, 1968. Forty Years Later, ed. M.M. Stolarik, Mundelein 2010, pp. $245-247$.

${ }^{121}$ M. Sarotte, Dealing with the Devil. East Germany, Détente, and Ostpolitik, 1969-1973, Chapel Hill 2001, pp. 68-69. 
to out-weigh another in modern Polish history: the German invasion of 1 September 1939. ${ }^{122}$ This was to be Gomułka's last triumph. He was ousted two weeks later, together with Cyrankiewicz (Prime Minister since 1956), following popular protests on the coast.

The cause of Baltic protests was drastic price increases announced a fortnight before Christmas. In retrospect, the 'December events' were a catalyst for the Polish decade to come. Key demands of 1980, including the call for independent trade unions, had already been articulated in the strikes of $1970 .{ }^{123}$ However, this first round was brutally repressed, the official figure of 44 workers dead was an underestimate. At least 1.164 were wounded.

After haranguing the Soviet Ambassador, Gomulka had phoned the Kremlin, but Brezhnev was unresponsive. He did not endorse Gomułka's claim that "counter-revolutionary elements, diversionaries inspired by counter-revolutionary circles" were rampant on the Polish Coast. Nor did he accept Gomulka's dramatic analogy with suppression of the Kronstadt uprising against Bolshevik rule in 1921. Rather than military means, the Kremlin offered "political support and credits, including hard currency, to rescue the parlous material position of the Polish economy." "124 A top secret letter to the Polish Politburo (18 December) stated that its Soviet counterpart lacked full information about the political situation in
Poland. Although they expressed disquiet about recent disorders, the use of force was not endorsed. Instead, Moscow called for "concrete political and economic steps" to calm the situation, without specifying what these should be. ${ }^{125}$ Gomulka was not mentioned.

Brezhnev told his successor, Gierek, "We did value Gomulka as Party leader, but when we considered that matters had taken a bad turn, we wrote our letter to the Polish Politburo saying we did not support that. Comrade Gomułka left office and we are happy that the authorities now have a new leadership."126 Soviet military strategy had been jeopardised by the deployment of Polish forces against its own people. When they discovered they were not facing German aggressors but their own kith and kin, many soldiers laid down their arms or deserted. Their loss of morale had implications beyond Poland's borders. As a Western analyst observes, "For the Russians, the continuing use of Polish soldiers against civilians was fraught with the imminent danger that another key Northern Tier, non-Soviet Warsaw Pact army would thereby be rendered operationally useless, only two months after the disintegration of the Czechoslovak army in the aftermath of the 1968 invasion." 127 Within Poland itself, the political agenda had shifted. While 1956 had been a national uprising demanding greater sovereignty, those of 1970 and after sought greater freedom within the socialist system.

\footnotetext{
122 P. Bender, East Europe in Search of Security, London 1972, p. 58.

${ }^{123}$ R. Laba, The Roots of Solidarity. A Political Sociology of Poland's Working-Class Democratisation, Princeton 1991.

${ }^{124}$ Grudzień 1970 w dokumentach MSW, ed. J. Eisler, Warszawa 2000, pp. 238-241.

${ }^{125}$ Tajne dokumenty Biura Politycznego. PRL-ZSRR, 1956-1970, ed. A Paczkowski, Londyn 1998, pp. 661-662.

${ }^{126}$ Tajne dokumenty Biura Politycznego. Grudzień 1970, ed. P. Domański (A. Paczkowski), Londyn 1991, p. 131.

${ }^{127}$ A. Michta, Red Eagle. The Army in Polish Politics, 1944-1988, Stanford 1990, p. 70.
} 
Gierek began a policy of opening Poland to the West. Instead of Gomułka's austerity and isolation, Warsaw sought loans and new technology to modernise the economy. The plan was that debts would be repaid by exporting finished products to the creditor nations. However, following the quadrupling of oil prices from 1973, Western markets dried up. By mid-1975, Polish debts had reached a serviceable maximum. Rescheduling was essential, but was complicated by a new development in European politics: the Helsinki process. The more astute Eastern European leaders, including Gierek, understood that there would now be a linkage between technical and financial assistance from the West and observance of the Helsinki Agreement.

Moscow had long called for a Security Conference to formalise the post-war status quo in Europe: an initiative dating back to Molotov in 1954. A few months after their invasion of Czechoslovakia, the Warsaw Pact re-issued this in the form of a "Budapest Appeal", no longer precluding North American participation. Given the West German aim of finding ways towards reunification without resurrecting fears in other parts of Europe of a "German danger", Bonn intended the mooted conference on security to go beyond conservative goals stated by the Warsaw Pact. They wanted it to give guarantees protecting all European countries from the threat of use of force and to prohibit any interference in the internal affairs of other countries. A wid- ened agenda of multilateral cooperation should improve the political climate on the continent, and then broaden the economic and technological cooperation amongst them, thus gradually freeing-up the peoples of the Eastern bloc.

Rather than simply ratifying the status quo, therefore, Bonn thought the conference should enshrine principles of national sovereignty and non-interference in internal affairs. In short, it should negate the Brezhnev Doctrine. ${ }^{128}$ The new French President, Pompidou, gave cautious support to this new policy. Reversing the Gaullist vision, he supported a continued US military presence in Europe and thought the US should "naturally" participate in a security conference since it was not "foreign to European problems". He told Willy Brandt that a security conference could "shake up the Eastern bloc as a bloc" and eventually dissolve blocs altogether. ${ }^{129}$

West European governments began to formulate a wider declaration on the principles guiding relations between the participating states. It was not intended to produce a regional law for Europe, but rather to bring the continent within the universally-accepted principles of international law, applicable irrespective of political or economic systems, ideologies or alliances. This contradicted the Warsaw Pact proposal that any new agreement could not supersede previous multi-lateral or bi-lateral alliances. Western governments insisted on principles of the non-use of force, territorial integrity, political independence

\footnotetext{
${ }^{128}$ G. Bernardini, Forced to Cooperate. The Brandt Government and the Nixon Administration on the Road to Helsinki [in:] Perforating the Iron Curtain. European Détente, Transatlantic Relations, and the Cold War, 1965-1985, eds. P. Villaume, A. Westad, Copenhagen 2010, pp. 79-100.

${ }^{129}$ G.-H. Soutou, Convergence theories in France during the 1960s and 1970s [in:] The Making of Détente, Eastern and Western Europe in the Cold War, 1965-75, eds. W. Loth and G. Soutou, London 2008, pp. 33-37.
} 
and the right to self-determination, all clearly contrary to the Brezhnev Doctrine. They made clear that Western Europe would not subscribe to any other declaration of principles. Moreover, there was a new addendum: respect for human rights. Whilst Moscow insisted that détente was a relationship between states, Western governments insisted that improving human contacts were a vital means of reducing international tensions, hence promoting peace and security on the continent.

In redrafting, the West agreed an addition to Principle 1 (sovereignty) that "participating states respect each other's right to choose and develop their own political, social, economic and cultural systems". Principle X (obligations under international law) stated: "In exercising their sovereign rights, including the right to determine their laws and regulations, they will conform to their obligations under international law." Hence the Soviet state-centric concept of non-intervention in internal affairs was now joined by an explicit recognition of respect for individual freedom. Principle VII (human rights) and Principle VIII (people's self-determination) contradicted the Brezhnev Doctrine, as did clauses favouring "freer movement of peoples and ideas."

The Helsinki Final Act (July 1975) therefore did not simply confirm the post-war territorial arrangement in Europe, as its US critics feared, but gave new scope to governments, non-governmental organisations and citizens to transcend traditional Cold War boundaries. Unexpectedly, it opened a new era in European politics. Daniel Thomas considers that the inclusion of human rights in the Final Act had even wider consequences, including the demise of communism and ending of the cold war. "The »Helsinki effect" surprised the diplomats who negotiated it, the politicians who signed it, and many others who had rushed to criticise it as a concession to dictatorship." 130

As Keith Hamilton explains "Its Declaration of Principles was in effect a political code of good behaviour which, since it applied unreservedly to all participating states, irrespective of economic, political, and social differences between them, implicitly rejected the Brezhnev Doctrine of limited sovereignty. It emphasised the self-determination of peoples, human rights and fundamental freedoms, and the Act's provisions dealing with human contacts, information, culture and education (the so-called »Basket Three« issues) stipulated how such principles might be transformed into practice." 131 Despite its title, the conference was not primarily concerned with security issues, but rather with enabling the human contacts that had potential to transform lives on the continent.

Western indebtedness was now a crucial and complicating factor in Polish internal politics. At the Helsinki ceremony, Schmidt and Gierek signed an agreement by which West Germany provided 2,3 billion Deutschmarks in credits and

\footnotetext{
${ }^{130}$ D.C. Thomas, The Helsinki Effect. International Norms, Human Rights, and the Demise of Communism, Princeton 2001 , p. 4.

${ }^{131}$ K. Hamilton, Cold War by other means. British diplomacy and the conference on security and cooperation in Europe, 1972-1975 [in:] The Making of..., p. 69.
} 
reparations in the exchange for Poland granting exit visas to those of the 125,000 ethnic Germans who wished to emigrate. ${ }^{132}$ Gierek needed to postpone another confrontation with society for as long as possible - the last one had removed his predecessor - but the time span was rapidly shrinking. As one commentator noted, Gierek had been pursuing "simultaneous and increasingly hectic love-affairs with Polish housewives and Western bankers." One party would have to be disappointed and it was unlikely to be the bankers. ${ }^{133}$

When the quadrupling of oil prices sent Western economies into recession, the Soviet Union expected to be immune. But by the end of the Seventies, the Soviet economy looked increasingly backward, and unable to innovate except in the fields of rocketry and aviation. Moreover, super-power relations had cooled considerably. The Carter presidency began to take a more robust approach to Soviet Third World expansionism. Not restricted to condemning Soviet-sponsored interventions, via Cuban forces, in southern Africa, this later crystallized into the Carter Doctrine, 1980 (Persian Gulf, Afghanistan) "Let our position be absolutely clear: An attempt by any outside force to gain control of the Persian Gulf region will be regarded as an assault on the vital interests of the United States of America, and such an assault will be repelled by any means necessary, including military forces."134

Détente had given way to a more active human rights agenda by the time of the Belgrade
Review Conference (late 1978). President Carter used the occasion to press for rigorous monitoring of human rights in Eastern Europe. In reply, the Soviet leadership accused him of interference in their internal affairs. However, a proliferation of "Helsinki Watch" committees provided ample evidence for Carter's accusations. The Polish report alone catalogued human rights abuses by its own government over 130 pages. A major section concerned the renewal of public protests over price increases announced by the government on 28 July 1976, and withdrawn by the Prime Minister on television later the same day. Polish workers had exercised a veto over a major element of Party policy.

Following arrests of strike leaders in summer 1976, a small number of intellectuals of varying political persuasions formed a Workers' Defence Committee (KOR) to provide legal representation and monitoring at their trials, and to give financial and moral support to the families of those imprisoned. The fourteen founding members acted openly, attaching their names and addresses to public statements. ${ }^{135}$ Deciding to have no formal structure or leadership, thus avoiding the legal requirement of registration (which would have been denied), KOR established new standards of non-violent resistance. Their initiative was surprisingly effective. All Polish workers imprisoned for their protests had been released by mid-1977 and reinstated, though sometimes to inferior positions. KOR members themselves, whilst subject to routine harassment by the

${ }^{132}$ D.C. Thomas, The Helsinki Effect..., p. 167.

${ }^{133}$ P. Green, Third Round in Poland, "New Left Review" 1977, I/102-102, February-April.

${ }^{134}$ B. Loveman, No Higher Law:..., p. 317.

${ }^{135}$ J.J. Lipski, KOR. A History of the Workers' Defense Committee in Poland, 1976-1981, Berkeley 1985. 
authorities, remained at liberty. This contrasted with repression of signatories to Charter '77 in neighbouring Czechoslovakia. ${ }^{136}$

The Pope used the first pilgrimage to his homeland (2-10 June 1979) to call for an authentic dialogue between Church and state despite their "diametrically opposed concept of the world." Some 12 million Poles saw the Pope in person and heard his cycle of thirty-two sermons. These vast gatherings were stewarded by the Church itself. There had been a temporary displacement of the communist state. ${ }^{137}$

When the Soviet-backed President of Afghanistan was assassinated in spring 1979 Moscow suspected a US-sponsored coup, which would allow the Americans to place "their control and intelligence centres close to our most sensitive borders." ${ }^{138}$ Defence Minister Ustinov and KGB chief Andropov - who had been closely monitoring Afghan events - pushed for Brezhnev towards military intervention. They argued that worsening relations with Washington made it more likely that the US were secretly helping the assassins in Afghanistan to undermine the Soviet position. The invasion was launched on Christmas Day 1979 without Politburo approval. It cost 50,000 Soviet and more than 1.2 million Afghan lives, signalled the Soviet Union's increasing international isolation, demonstrated the operational weakness of its enormous military capacity and ended super-power détente, but may have saved Poland.
On 1 July 1980, Gierek attempted a third round of price increases. There was no public announcement: local Party officials were instructed to raise prices if and when they could. Its timing in the July holidays was thought most likely to avoid mass demonstrations. Where they did occur, Warsaw's instruction was to pay a modest wage compensation. This sufficed until workers learned of more generous increases at neighbouring enterprises and again struck to demand an equal rate. The first major protests were in the eastern city of Lublin, which had come to a standstill - including the strategic railway line between the USSR and the West- by mid-July. ${ }^{139}$ The Moscow Olympics were just days away, despite a Western boycott in protest at the invasion of Afghanistan. Gierek, hurriedly returning from the Crimea on a special plane, told the Politburo that 'if the strike drags on we can expect questions from the Russian comrades.' Defence Minister Jaruzelski was more explicit about Soviet reactions: "continued stoppages would pose a threat to the (Polish) nation." 140 The Lublin strike was settled by negotiations with a government mediator Mieczysław Jagielski, who soon faced a far harder task at the Gdańsk Shipyard.

Animated discussion of the Lublin events had taken place on the Coast, but political activists thought there was no real prospect of doing the same: another year would be needed before widespread support was forthcoming. However, an opportunity was presented by the summary

\footnotetext{
${ }^{136}$ H.G. Skilling, Charter 77 and Human Rights in Cqechoslovakia, London 1981.

${ }^{137}$ J. Lityński, Wielkość i małość, "Robotnik" 1979, No. 34, Vol. 20, June.

${ }^{138}$ O.A. Westad, The Road to Kabul: Soviet Policy on Afghanistan, 1978-1979 [in:] The Fall of Detente: Soviet-American Relations During the Carter Years, ed. idem, Oslo 1997, pp. 132-142.

${ }^{139}$ M. Dąbrowski, Lubelski Lipiec 1980, Lublin 2000.

${ }^{140}$ AAN, 237/V/1816 Protocol no. 13, 18 July 1980, pp. 2-3.
} 
dismissal of Anna Walentynowicz, a popular crane operator, just five months before she was due to retire. Protests began at the Gdańsk Shipyard early on 14 August. Kania convened an emergency session of the Politburo - Gierek was away again in the Crimea - to inform it of the strikers' demands. In addition to reinstatement of Walentynowicz and compensating wage rises, they called for "independent and self-governing" trade unions, the right to strike, release of political prisoners and building a memorial to the victims of the December 1970 shootings outside the Shipyard's Gate 2. He also noted the demand from two members of KOR for reinstatement of another worker, Lech Wałęsa, "linked to the Kuroń group." "141 Within two days, the Gdańsk Shipyard became the headquarters of a regional general strike. The Politburo decided to approach the Vatican with a request that the Pope help to pacify the strikers. Even the hawkish Kruczek remarked: "Talks with the Vatican are suitable. We must defend the factories against the terror of KOR". ${ }^{142}$

When sent to Gdańsk as government negotiator (23 August), Jagielski faced an Inter-Factory Strike Committee representing more than 400 coastal enterprises. ${ }^{143}$ Reporting back on the first round of talks, Jagielski noted his team's rowdy reception. "At the Shipyard Gates stood an enormous aggressive crowd. Mainly young people
- the older ones behaved peacefully - shouted hostile slogans: »lynch them«, »kill them«, »hang them«, »crawl on your knees«." He described the session that followed as "debasing and humiliating." 144 Olszowski was the most forthright Politburo member, proposing to go on television "to spell out exactly what this new union business is about, unmask it. Tell the workers we want union renewal, elections where necessary, that we are not afraid of criticism, but that unions are their own concern, not the business of outside »helpers.« The Party - like it or not - is responsible for the country and we cannot agree to the formation of an anti-socialist structure. Spell out the dangers (Czechoslovakia, Hungary)." "145 Pińkowski outlined three ways to control the strike: (1) "Political struggle" was the most important; (2) "Administrative measures" could only be used "when we are able to enforce our decisions;" (3) "Force" was possible, but only as a last resort. ${ }^{146}$

Kania addressed provincial Party leaders that evening. The demand for "free trade unions" had not come from workers, but "from antisocialist gamblers, for eighteen months or two years grouped around Kuroń, here in Warsaw". They "sought to set up an anti-socialist structure which would not defend workers' interests, but mount an attack on the foundations of our system, aiming to use it as a means of taking pow-

\footnotetext{
${ }^{141}$ AAN, 237/V/1816 Protocol no. 16, 14 August 1980.

${ }^{142}$ AAN, 237/V/1816 Protocol no. 20, 20 August 1980.

${ }^{143}$ The transcript of Negotiations is in: A. Kemp-Welch, The Birth of Solidarity: The Gdansk Negotiations, 1980, Macmillan/St. Antony's College Series, Oxford 1983, pp. 35-148; enlarged second edition The Birth of Solidarity, Oxford 1991.

${ }^{144}$ AAN, 237/V/1816 Protocol no. 24, 24 August 1980.

${ }_{145}$ AAN, 237/V/1816 Protocol no. 26, 27 August 1980.

${ }^{146}$ AAN, 237/V/ 1816 Protocol no. 26, 27 August 1980.
} 
er into their own hands, disrupting the normal functioning of the state."147 Gierek concurred, saying that the Shipyard strike had been incited from outside, by members of the intelligentsia for their own political ends.

Soviet "advisors" had been in Poland since mid-August, rehearsing plans for martial law. Code-named "Lato-80" (Summer 1980), they were to be imposed with or without direct Soviet military intervention. ${ }^{148}$ One scheme, devised by the Interior Ministry, was to send troops by helicopter to storm the Shipyard and make mass arrests. Gierek came under strong pressure to end the strike. The Soviet Ambassador Aristov was "categorical, strongly warning of insecurity." "The strikes reminded him of "anarchosyndicalism", one of the most dreaded heresies in Soviet history. Lenin had expelled its advocates in spring 1921 and imposed a temporary "ban on factions" in the Party. This lasted seventy years.

Soviet leaders established a task-force (25 August) "to keep the Politburo systematically informed about the state of affairs in Poland and about possible measures on our part." Its membership included Andropov and Ustinov and was convened by Suslov. The first report of this "Suslov Commission" (28 August) was a top secret "special dossier" on how to form a group of forces "in case military assistance is provided to Poland". Given their assessment that the loyalty of Polish forces could not be relied upon, and the possibility that "the main forces of the Polish army (may) go over to the side of the counterrevolutionary forces," major mobilisation was authorised on Poland's eastern borders. ${ }^{150}$

Plans to storm the Shipyard were again discussed in the Polish Politburo (29 August), but having received no response from Moscow on the use of force, Gierek canvassed other options. Some of his colleagues wanted to abort negotiations and impose a "state of emergency." Its future architect, Jaruzelski, remarked prophetically that such a measure did not exist within the Polish constitution, which only made provision for a "state of war". Kania dismissed as "fantasy" the contention that Polish security forces could "exterminate the counter-revolutionary nest in Gdańsk." Gierek reluctantly concluded that the remaining option to avert a national general strike was a rapid conclusion to negotiations, even though this would legitimize a "free, selfgoverning trade union" on the Coast, at least for the time being..$^{151}$ Accordingly, final negotiations were rushed through and the Gdańsk Agreement, accepting all the Twenty-one Demands was signed on 31 August. ${ }^{152}$ The Szczecin Agreement had been signed the previous day..

Soviet leaders sent Warsaw a top secret memorandum "On theses for discussion with representatives of the Polish leadership" (3 September). It stated that agreements with the "so-called »United Strike Committees« in Gdańsk and Szczecin”

\footnotetext{
${ }^{147}$ AAN, 237/V/ 1816, 27 August 1980, evening.

${ }^{148}$ B. Kopka, G. Majchrzak, Stan wojenny w dokumentach władz PRL (1980-1983), Warszawa 2001, Page nos.

149 Z. Włodek (A. Paczkowski) (ed.), Tajne dokumenty Biura Politycznego. PZPR a „,Solidarnośc”, 1980-198, Londyn 1992 , p. 78.

${ }^{150}$ M. Kramer, New Evidence on the Polish Crisis, 1980-1981, “Cold War International History Project Bulletin” 1998, Issue 11, p. 108.

${ }^{151}$ AAN, 237/V/1816 Protocol no. 28, 29 August 1980.

152 The text of the Agreement is in: A. Kemp-Welch, The Birth of..., pp. 188-199.
} 
amounted to "legalization of an anti-socialist opposition." However, the struggle against the opposition, which aimed to extend its political influence nationwide, was complicated by the fact that they had cunningly disguised themselves as defenders of the working class. Moscow suggested traditional remedies: restore the "leading role" of the Party and revive trade unions, but in a sharp departure from Soviet practice suggested "attract army leaders to perform Party-economic work as well."

Personal criticisms were added in a postscript. "Given the critical situation that has arisen in Poland, we would like to remind our Polish friends of the advice and suggestions made by Comrade L.I. Brezhnev during conversations with E. Gierek in the Crimea in 1979 and especially on 31 July 1980, as well as in his letter to the Polish Central Committee on 21 August 1980. These were to attack political enemies, rather than going on the defensive, and 'decisively rebuff all attempts to use nationalism to stir up anti-socialist and anti-Soviet sentiments' and misrepresent the history and cooperative nature of Soviet-Polish relations." 153 The charges were elaborated at a Warsaw Pact summit later in the year. Brezhnev said he had repeatedly told Gierek: "a resolute campaign against anti-socialist elements is necessary. But all we heard in response was »Nothing is going on, no opposition exists, the Polish government and Party are in control of the situation «." 154 Kania, already de facto in charge, formally replaced Gierek on 6 September.
The new Party Secretary sought time and space in which to negotiate the compromise which he saw as essential to preventing the bloodshed that use of domestic forces or a Warsaw Pact invasion, or both, would inevitably entail. Such pragmatic concerns found resonance within the leadership but were also challenged by more hostile attitudes. At a conference of Party Secretaries, Andrzej Żabiński portrayed the formation of "independent, self-governing trade unions" as the first stage of an elaborate oppositional agenda "to dismantle the central institutions of the socialist state". The next step would be to disrupt the youth movement, and then to attack "other representative and social institutions, the national council, parliament (Sejm), to demand changes to the electoral laws and finally attempt to undermine the leading role of the Party." ${ }^{155} \mathrm{He}$ presented this as 'a hypothesis' and gave no evidence.

While Kania sought to conciliate, Soviet ideologists bombarded him with memoranda portraying Solidarity as an intolerable deviation from Leninism and a mortal threat to one-Party rule. Scouring the scriptures for texts with which to berate the Polish comrades, they sent lengthy philippics contesting the term "free trade union". Ignoring the fact that Solidarity had called itself "independent and self-governing" (not free), they asked "free from whom or what"? Lenin had taught that the "so-called sneutrality" of trade unions" was a hypocritical disguise, but such "elementary truths" had not been understood

153 TsKhSD, Fond 89, opis' 66, delo 37, Protocol of the Politburo CPSU, 3 September 1980.

${ }^{154}$ Warsaw Pact summit, 5-6 December 1980.

${ }^{155}$ AAN, 237/V/1816, "Conference of First Secretaries of the CC PZPR, 16 September 1980”. 
by "the former leader of the Gdańsk strike committee Lech Wałęsa." Using his "free union", Poland's political opposition sought to wrest influence over the working-class from the PZPR. This would lead to counter-revolution. Bourgeois circles in the West were already claiming that "independent unions" were "the first step in Poland's transition to a pluralist system." "156

Brzeziński convened a White House "Meeting on Poland" on 23 September. As National Security Advisor, his aim was to avoid the passivity of US policy during the 1968 crisis, and to attempt to influence Soviet leaders by articulating in advance what sanctions would follow an invasion of Poland. He recalls that "I realised this would not be a decisive factor in Soviet calculations, but I felt that under certain circumstances it could make more than a marginal difference in the event of any internal Kremlin disagreement." 157 The meeting heard an intelligence assessment that "Kania has not yet turned the corner on controlling events. Unrest is spreading." But the DCI Director felt that, "unless the situation deteriorated drastically", the Soviet Union would not intervene before Polish crops had been harvested in mid-October. There was consensus that the Poles would fight, though it was not clear how organised such resistance might be. ${ }^{158}$ Brzeziński saw some scope for diplomatic pressure. He thought the Soviet Union could be deterred by Polish resistance, the possibility of a strong West European response and the fear of a Chinese reaction. His advocacy of "closer
US-Chinese military cooperation", which played on the Soviet phobia of encirclement, was likely to have psychological rather than military significance.

As Solidarity strove for legal registration, Moscow grew steadily more impatient. On the eve of a visit by Kania and Pińkowski, Brezhnev told the Politburo: "Poland now has a fully raging counter-revolution." Andropov agreed: "Anti-socialist elements, such as Wałęsa and Kuroń, want to seize power from the workers... but we see nothing about it in the Polish press." Gromyko insisted the visitors should be directed to impose a state of emergency: "We must never lose Poland. In its struggle with Hitler while liberating Poland, the Soviet Union lost of 600,000 of our soldiers and officers. We cannot tolerate counter-revolution." Suslov reflected on the more recent past: "We once wrote a letter to Gomułka (18 December 1970) so that he would not take up arms against the workers, but he did not listen to our voice. The Polish leadership did take up arms then." 159

Following the visit, Brezhnev told the Politburo "Events in Poland have deteriorated so far by now that if we let time slip by and do not correct the course taken by the Polish comrades, we will - before you know it- be faced with a critical situation, which necessitate extraordinary and, one might even say painful decisions." "Extraordinary" meant military intervention. But he also noted the financial constraints. "Poland is completely immersed in debt. All imports from the

${ }^{156}$ AAN, 237/V/ 3976, (Kania), pp. 1-3.

157 Z. Brzeziński, Power and Principle. Memoirs of the National Security Adviser 1977-1981, New York 1983, p. 465.

${ }^{158}$ NSA, Special Coordinating Committee, 23 September 1980.

${ }^{159}$ TsKhSD, Fond 89, opis' 42, delo 31, CPSU Politburo, 29 October 1980. 
West, which are needed for many exporting enterprises to function, as well as for supplying the domestic market, are now obtained on credit". Given their dependence on the West, the visitors explained that "any deterioration of their country's situation might give the basis for the capitalists to refuse any further extension of credits. In that case, Kania said, Poland will be brought to its knees." $" 160$

As fears of "spill-over" spread across the Warsaw Pact, Brezhnev requested East Germany accept a reduction in Soviet oil supplies, enabling Moscow to sell in the West and supply Poland with the hard currency. His prediction was dire: "You well know the political situation in Poland. Counter-revolution is advancing and almost has the Party by the throat." He echoed his own Doctrine: "Further aggravation of the Polish situation threatens to inflict grave damage on the whole socialist commonwealth. Therefore it is an internationalist, I would say class duty to do everything in our power to prevent this happening.""161

Bulgarian leaders discussed Poland on 25 October. Mladenov contrasted it with Czechoslovakia in 1968. "It is true that the aims are the same, but the essential difference in my view is that while there the Pelikans and Dubčeks, who emerged as distinctive heroes and personalities, here the masses came out in their millions. They are already speaking of eight million (in) Solidarity." Although the Polish leadership was calling for "renewal", Mladenov thought they really meant a new model of socialism. "They will not move towards the Yugoslav model, but rather seek a model closer to that of Sweden or Austria under Kreisky, which would have pluralism in the sphere of politics and ideology." 162

The increasing chorus of protests from "fraternal countries" found some counter-part in the Polish leadership. Grabski told the Secretariat that the country's economy was being deliberately disrupted. "Solidarity wants to bring the government to its knees, to control it on a lead, to put pressure on elections, to threaten protests and demonstrations. It's not complex, comrades!" But he urged domestic intervention. "The decision on a confrontation must not be taken from us. That is what Honecker and Bilak are proposing." 163

There was now wide consensus in the West that the Soviet Union would invade Poland. Indeed, the military option was meticulously planned even though its commander-in-chief denied this at the Jachranka conference. The seventy-six year old Marshal Kulikov, bedecked, bemedalled, and beribboned, solemnly informed the conference "a plan for our army, the army of the Warsaw Pact, to enter Polish territory did not exist." 164 Later in proceedings he conceded that there had been "outline" plans, but nothing finalised for specific action. Confronted by evidence of plans to use East German and Czechoslovak forces, he eventually admitted the existence of

\footnotetext{
${ }^{160}$ TsKhSD, Fond 89, opis' 42, delo 35 “On the Results of a visit to the USSR”, CPSU Politburo, 31 October 1980.

${ }^{161}$ NSA. "Letter from Leonid Brezhnev to Eric Honecker," 4 November 1980.

${ }^{162}$ Politburo of the Bulgarian CP Central Committee, 25 October 1980.

163 AAN, 237/V/2254, Secretariat, 25 October 1980.

${ }^{164}$ Wejdq nie wejdq..., p. 202.
} 
a plan. He added in conversation that he could have carried out the invasion with complete professionalism, as he had in 1968. But that required a political decision which was never taken. ${ }^{165}$

Soviet military preparations had been made for overwhelming strategic reasons. As Kramer puts it: "Because of Poland's location in the heart of Europe, its communications and logistics links with the Group of Soviet Forces in Germany, its projected contributions to the "first strategic echelon" of the Warsaw Pact, and its numerous storage sites for Soviet tactical nuclear warheads, the prospect of having a non-communist government in Warsaw or of a drastic change in Polish foreign policy generated alarm in Moscow."166

A further Soviet concern was the reliability of the Polish army. Exposure of new recruits to the heady political atmosphere since summer 1980 had reduced its potential as a domestic force to suppress Solidarity. By November, senior Party officials worried that "some $60 \%$ or $70 \%$ of the army is inclined towards Solidarity". Kania agreed and warned: "Among new recruits are those who have taken part in strikes, or whose parents have done so. This means that political indoctrination and discipline in the army and security forces are of utmost importance. We must bear in mind the influence that families have on new recruits to the army and security forces."167 Such impact could only increase through time.
Kania addressed a summit of the Warsaw Pact (5 December). His first speech at this forum stressed awareness of "internationalist responsibility", defined as the Polish leaders managing to resolve the crisis on their own. He emphasised its antecedents: "This is not the first, but one of a sequence. We had the year 1956 and the bloody events in Poznan, with the ensuing changes in Party leadership and the great wave of revisionism in Poland. There was the year 1968, the street riots of students and the very dramatic events 1970 on the Polish Coast. Finally in 1976, Radom and Ursus demonstrated sharply against price increases." 168 The current crisis concerned the working class and had a mass character, but domestic tensions were being exacerbated by the West, "in particular Radio Free Europe and centres of reactionary émigrés, supporting antisocialist actions through propaganda and financial aid to Solidarity." In response, the Party had contingency plans, including giving weapons to trustworthy members: 30,000 would be armed by the end of December. The key to domestic resolution of Poland's problems was a reinvigorated Party, strengthening its ideology and discipline and eliminating 'fractional activity.' ${ }^{169}$

Warsaw Pact leaders varied considerably in their response. Zhivkov was unremitting in his hostility to capitalist interference. "The West's strategic plan is clearly to install a different

\footnotetext{
${ }^{165}$ One detected a note of disappointment in his face.

${ }^{166}$ M. Kramer, Poland, 1980-81. Soviet Policy During the Polish Crisis, “CWIHP Bulletin” 1995, Issue 5, Spring, p. 118.

${ }^{167}$ M. Kramer, Translator's Note, Theses for Discussion with Polish Leaders, “CWIHP Bulletin” 1995, Issue 5, Spring, p. 40, n. 9; idem, CPSU CC Politburo Report "On Theses for the discussion with representatives of the Polish leadership”, 3 September 1980, "CWIHP Bulletin” 1995, Issue 5, Spring, pp. 116-117, 129-130.

168 Stenogram ze spotkania przywódców państw członkowskich Układu Warszanskiego, 5 grudzień 1980, in: Przed i po 13 grudnia. Państwa bloku wschodniego wobec kryzysu w PRL 1980-1982, t. 1, wybór, wstęp i opracowanie L. Kamiński, Warszawa 2006, s. 236.

${ }^{169}$ Ibidem, p. 238.
} 
system in Poland which diverges from real socialism and is directed to liberal socialism, a model which could be an example and provoke changes in the social order of other countries of the socialist community." 170 Kadar, though less anxious about infection from the "Polish disease", also noted "in the present complicated international situation, events in Poland affect both Europe and the Warsaw Pact." The "class-enemy" had learned from past events in Hungary, Czechoslovakia and now in Poland. While formally accepting the "leading role" of the Party in building socialism and membership of the Warsaw Pact, "in reality they seek to drive back socialist forces in all areas." ${ }^{\text {"171 }}$ Honecker recalled a conversation with Dubček in March 1968. "He tried to convince me what was happening in Czechoslovakia was not counter-revolution but a process of »democratic renewal of socialism «. Everyone knows what happened after that." ${ }^{172}$ Ceausescu was most cautious. After expressing his bewilderment that "so-called independent unions" had come into being, he insisted that the Polish comrades ensure socialist construction on their own. "We cannot overlook the fact that the possibility of an external intervention would pose a grave danger to socialism in general, to the policy of détente and the pursuit of peace."173

Afterwards, Kania was summoned by Brezhnev to discuss possible Polish responses to intervention by the Red Army and the Warsaw Pact. Kania described the likely reaction of Polish society: "Young lads will throw petrol bombs at the tanks, as in the Warsaw Uprising, and streets will be swimming in a sea of blood. Even if angels invaded Poland, they would be treated as bloodthirsty aliens." He recalled "I reminded him of the sensitivity of Poles to sovereignty, to the rape of the country's independence that had no equal in Europe." Brezhnev replied: "we will not go in", but added "without you - we will not go in." 174 Kania pondered this proviso on the flight home.

Washington concluded that the invasion of Poland had been put on hold. The summit's communiqué was "deliberately moderate, possibly to cover the tough message. The paragraph on Poland was deliberately left to the end, following favourable references to détente, CSCE and relations with the US. The statement that Poland was, is, and will remain a member of the socialist camp is put in the mouth of the Polish delegation. The clear message of the meeting is that Poland will remain in the Warsaw Pact." An accompanying analysis suggested that "Poles were being given a last chance to solve their problems on their own." The Poles had given "a last warning that they had better succeed in mastering the situation quickly since there were limits to Soviet tolerance and the Brezhnev Doctrine still applied." 175

The incoming Secretary of State, Haig, wrote a letter to Gromyko "expressing American concern over the threat to the Polish movement for social justice." ${ }^{176}$ His response was delivered by

170 Ibidem, p. 247.

${ }^{171}$ Ibidem, pp. 249-250.

${ }^{172}$ Ibidem, p. 259.

${ }^{173}$ Ibidem, p. 265.

${ }^{174}$ S. Kania, Zatrzymaí konfrontacje, Warszawa 1991, pp. 90-91.

${ }^{175}$ NSA, 'Soviet Flashpoints' Collection, CIA Situation Report "Poland", 7 December 1980.

176 A.M. Haig, Caveat. Realism, Reagan, and Foreign Policy, London 1984, p. 90. 
ambassador Dobrynin (29 January 1981). After denying there was anything concerning taking place, "Nothing happened in Poland today. We have put off consideration of the Polish problem until tomorrow", he handed over the letter. Its language was unequivocal. First of all, the internal affairs of a sovereign socialist state could not be a subject of discussion between third countries, including the USSR and USA. If one were to speak, however, of outside attempts to exert influence on the internal situation in Poland, then it would be necessary to state that such attempts do take place and that they were being undertaken precisely on the part of the USA and other Western powers. In this regard it was sufficient to mention at least the provocative and instigatory broadcasts of the Voice of America... those broadcasts were, inter alia, aimed at generating among the Polish population unfriendly sentiments with regard to the Soviet Union.

Haig regarded this as a minor masterpiece of Soviet evasion, a "mixture of truculence, accusation, and suspicion that jammed the normal frequencies of civilised discourse". ${ }^{177}$ Even so, Gromyko's epistle ended by expressing Soviet readiness for bi-lateral talks across a wide range of international issues.

Washington considered no super-power summit was possible "while the shadows of Budapest and Prague fell across Poland," but the policy was also to avoid "fishing in the Soviet Union's troubled waters in Eastern Europe." Haig pondered the future. The Soviets asserted a sphere of influence in Eastern Europe that Western powers had acknowledged at Yalta. But "was the bargain struck at Yalta ineluctable? This was a question worth raising. Did the universal application of the Brezhnev Doctrine mean that past understandings, however abused, no longer applied? Or was the Soviet strategy of wars of liberation a prelude to the suggestion of condominium between the super-powers?" 178 Haig noted that both the Chinese and the Europeans themselves, were fearful of such a prospect, which US policy should avoid at all costs.

Domestic solutions to the Polish crisis were planned in the strictest secrecy. Preparations for imposing martial law had been begun by the General Staff of the Polish Army, under Florian Siwicki, on 22 October 1980. Their original conception of what should be "suspended, prohibited, ordered, militarised, and de-legalised, where the army should be dispatched and who interned, was not too different from the law as finally implemented thirteen months later." ${ }^{\text {179 }}$ Full documentation of plans made by the National Defence Committee (KOK) was with the Ministry of Interior (MSW) by 20 January 1981. They were "tested" during "staff games" by the army and MSW on 16 February in the presence of a team of "consultants" sent from Moscow. Final preparations were made over the spring and summer, and by mid-September were lacking only an implementation date and the necessary signatures. ${ }^{180}$ During almost a year's preparations, no mention of them was made to parlia-

${ }^{177}$ A.M. Haig, Caveat. Realism, Reagan..., p. 104.

${ }^{178}$ Ibidem, p. 105-106.

${ }^{179}$ Wojna z.narodem widziana od środka, interview with Ryszard Kukliński, „Kultura” (Paris) 1987, No. 4.

${ }^{180}$ A. Paczkowski, O stanie wojenny. W sejmowej komisji odpowiedzialności konstytucyjnej, Warszawa 1997, pp. 143-144. 
ment, the government or even the Council of State, let alone public opinion. But full documentation was given to senior Red Army officers and KGB functionaries on at least two occasions.

Early 1981 saw two Soviet teams in Poland. A military delegation under Kulikov toured all military districts. Ostensibly visiting to verify the combat readiness of Polish troops, in reality they wished to gauge their reliability for domestic purposes. Polish officers were asked directly how they would respond to orders to break strikes and evict strikers from factories. ${ }^{181}$ A second, civilian, team, lead by Leonid Zamyatin, head of the CPSU's International Information department, used every meeting to admonish 'the enemy' seeking to destabilize Poland, its economy and thus weaken the Warsaw Pact. In Katowice, Zamyatin declared: "They know they cannot defeat us militarily, they cannot physically violate our borders, because this would receive a decisive rebuff. So they have chosen another way, one of ideological sabotage."182 Reporting back to the Soviet Politburo, he stated "Solidarity is now in essence a political party, activity hostile to the (communist) Party and state." Gromyko agreed: "Solidarity is a political party of an antiSoviet character." He deplored the porousness of Polish public life: "Everything discussed at the Politburo is known by the public next day." 183

The "Bydgoszcz Crisis" in the second half of March began with the eviction of two promi- nent Solidarity leaders from a provincial council meeting in support of Rural Solidarity. They were badly beaten up by security agents in plain clothes. This first use of force against Solidarity outraged its National Coordinating Commission, which called for a full public enquiry into this "obvious provocation aimed at the government of General Jaruzelski." Subsequent research by Andrzej Paczkowski indicates some fore-knowledge of the incident by the Ministry of Interior, though the extent to which they acted under authorisation or on their own initiative remains unclear. ${ }^{184}$

Wałęsa urged a cautious response. As his chief of staff put it: "Wałęsa was convinced of one thing: that Poland is not really a sovereign country and that it is just a pipe-dream to think we could, solely by our own efforts, effect the slightest change in her status." 185 Though he would not have used the language of sovereignty, Wałęsa was keenly aware of Poland's geopolitical situation.

As in previous crises, the Church acted as mediator. Cardinal Wyszyński warned Wałęsa in a private audience (26 March): “The situation is threatening. We have received signals that if certain limits are crossed, it will cease to be an internal matter." He told the Solidarity leader "The fate of Poland is at stake" and implored him to abort the planned general strike. ${ }^{186}$ Later that day, Wyszyński held his first, and only, audience with

\footnotetext{
${ }^{181}$ Wojna z.narodem..., pp. 31-32.

${ }^{182}$ AAN, 237/V/3982, Kania's Secretariat, Speech of 16 January 1981, pp. 1-4.

${ }^{183}$ RGANI, Fond 89, opis’ 42, delo 36, CPSU Politburo 22 January 1981.

${ }^{184}$ O stanie wojennym w Sejmowej Komisji Odpowiedzialności Konstytucyjnej sprawozdanie Komisji i wniosek mniejszości, wraz z ekspertyzami i opiniami historyków, Warszawa 1997, pp. 143-144.

${ }^{185}$ L. Wałęsa, A Path of Hope, Londyn 1987, pp. 189-190.

${ }^{186}$ W. Jaruzelski, Stan wojenny. Dlaczego..., Warszawa 1992, p. 88.
} 
Jaruzelski. The Polish Pope invited the Soviet envoy to Italy to the Vatican (28 March). In return for the pontiff's agreement to calm Solidarity, Moscow reportedly offered an assurance that it would not intervene in Poland for six months. ${ }^{187}$ Such mediation bore fruit. A four hour warning strike, unique in the history of communism, was observed by millions of Solidarity members, students and even school children. But tense negotiations with the Party leadership then led to a Warsaw Agreement (30 March) in which the government admitted some degree of responsibility for the Bydgoszcz incident. Wałęsa unilaterally rescinded the next day's general strike.

Talking to East German officers, Kulikov described "the view of Comrade Jaruzelski that the Polish Party and state leadership had won a strategic battle in Bydgoszcz" as "incomprehensible." Soviet leaders could no longer rely on him "to change the course of events". Jaruzelski had made a series of concessions: over Bydgoszcz, in youth work, ending (compulsory) teaching of Russian in schools and with regard to the Church. He concluded "One must frankly admit that the Polish Party (PZPR) is currently weaker than the Catholic Church and Solidarity." 188 Brezhnev was equally adamant, telling Kania by telephone "A general strike has been averted. But at what price? At the price of capitulation to the opposition". He added "You can't keep making endless concessions to Solidarity. You always speak about a peaceful path, but you don't under- stand (or at least don't want to understand) that a "peaceful path" of the sort you are after is likely to cost you blood." 189

For the moment, Polish politics calmed down. The Party held an extraordinary Congress (14-19 July), which failed to endorse either a belligerent or a benevolent stance towards Solidarity and the opposition. Its "centrist" posture was variously described as moderate, pragmatic or realist. Solidarity opened its First National Congress in Gdańsk (5 September).

This had received a message from the Moscow "Founding Committee of Free Trade Unions in the USSR", whose leaders had been denied visas to attend, declaring: "Your struggle on behalf of ordinary people in Poland is our struggle". They added that everything Solidarity was saying about official "lies and double-dealing with regard to realising workers' basic needs applies to the Soviet regime. Poland will never be free until Russia is free." ${ }^{\prime 190}$ Congress responded with its "Message to Working People in Eastern Europe" ${ }^{191}$ which conveyed greetings and support to the workers of Albania, Bulgaria, Czechoslovakia, the DDR, Romania, Hungary and all the nations of the USSR. "Contrary to the lies spread about us in your countries", Solidarity was an "authentic, ten-million strong representative of working people" which would support all those who embarked on the long and difficult road to a free and independent labour movement. "We believe it will not be long before your

\footnotetext{
${ }^{187}$ R. Gates, From the Shadows: The Ultimate Insider's Story of Five Presidents and how they won the Cold War, New York 1966, pp. $240-241$. 188 "Report of a Confidential Discussion with Warsaw Pact Supreme Commander", DDR Ministry of Defence, 7 April 1981. ${ }^{189}$ RGANI, Fond 89, opis’ 42, delo 39, CPSU Politburo, 2 April 1981.

${ }^{190}$ Ośrodek Karta (Warszawa) „Solidarnośc” - narodziny ruchu, cited by B. Kaliski, „Antysocjalistyczne zbiorowisko”? I Krajowy Zjazd Delegatón NSZZ Solidarność, Warszawa 2003, pp. 105-106 (Letter of 18 August 1981).

${ }^{191}$ For its authorship (Jan Lityński) see J. Holzer, Solidarność 1980-81. Geneza i historia, Warszawa 1983, p. 180.
} 
representatives and ours are able to meet to exchange experiences as trade unionists." ${ }^{192}$ This was passed by acclamation and a standing ovation, without discussion or interventions from the platform. ${ }^{193}$

Soviet leaders suspected - with good reason that Solidarity would have destabilising repercussions in other countries of the Warsaw Pact. The "Message to the East" gave credence to these expectations. Brezhnev denounced it at the next Politburo (10 September) as a "dangerous and provocative document". The Central Committee's Propaganda Department would draft expressions of outrage to be signed by major Soviet enterprises. A Politburo newcomer, Gorbachev, added: "I consider Leonid Ill'ich (Brezhnev) was completely right to propose that workers' collectives in large enterprises speak out, and that the activities of Solidarity should be unmasked in our press." 194

Soviet military advice was now against an invasion. Explaining this apparent shift, General Ogarkov gave four main reasons:

1. The Polish situation is quite different from Czechoslovakia in 1968. There it concerned the upper echelons of power; in Poland it concerns the whole nation. The Solidarity trade union is active in industrial enterprises, the countryside and educational establishments, and has supporters in all of them. The Church and the majority of intellectuals support the demands of Solidarity. It has its own information network, including press and ra- dio. It is fully supported by the West, materially, financially and morally.

2. The Polish armed forces are patriotic. They will not fire on their own nation. In the event of an invasion, Solidarity leaders will call for a struggle against invading forces. This could lead to civil war.

3. The Polish government should sit down to talks with the Solidarity leaders and resolve all questions in the national interest.

4. There are healthy forces in Poland. The army, Ministry of Interior and state security still function in the interests of the state.

Defence Minister Ustinov agreed. An invasion of Poland "would lose us authority world-wide and many friends. The West would not look kindly on such action." 195

Suslov continued to be the custodian of orthodoxy. He explained to the Central Committee (18 November) that "events in Poland demand a precise class position, a clear Marxist-Leninist account." Having earlier accepted private agriculture (despite Stalin's wishes) and a public role for the Catholic Church (despite Khrushchev), the Party's leading role was now weakened and the country was effectively a system of dual power. Moscow was being asked to accept a trade union independent of the state. His recommendations to Polish leaders were a classic statement of neoStalinist ideology:

1. Adhere to the basic laws of socialist revolution and socialist construction. This is "not a new but a profound and continuously

\footnotetext{
${ }^{192}$ Postanie do ludæi pracy w Europie Wschodniej, „Tygodnik Solidarność” 1981, No. 25, 18 September.

${ }^{193}$ Those of us observing from the gallery also leaped to our feet.

${ }^{194}$ M. Kramer, Soviet Deliberations during the Polish Crisis, 1980-1981, “CWIHP Special Working Paper” 1999, No. 1, pp. 137-140.

195 A.I. Gribkov, 'Doktrina Brezhneva' i pol'skii krizis nachala 80-kh godov, "Voenno-istoricheskii zhurnal” 1992, No 9 (September), p. 56.
} 
current truth. Be vigilant at all times."

2. Maintain the leading role of the communist Party and Leninist norms of inner-Party life.

3. Allow no place for neutrality or compromise in the struggle of ideas between socialism and capitalism.

4. Restore orthodoxy. Weak party-educational work has left the Polish working-class, youth and intelligentsia open to nationalism, revisionism and anti-Marxism.

Solidarity and "other reactionaries" were steering Poland in an anti-socialist and anti-Soviet direction. This was having adverse repercussions within international communism: Yugoslavia, "Romanian manoeuvring", Korea and Peking. These failings were exacerbated by "the aggressive forces of imperialism, especially the Reagan administration”. He cited a recent Brezhnev statement (4 November): "Socialist Poland can rely on its allies." ${ }^{196}$

Even so, Suslov did not favour an invasion. He concluded: "The military will not go in. An invasion would be a catastrophe for Poland, yes and for the USSR". This echoed Ustinov's curious statement: “there isn't going to be an invasion of Poland. If a new government comes to power we will cooperate with it". "We should activate the healthy forces in Poland... using our Ministry of Defence, KGB and Gosplan to help the Polish government mobilize its forces." After citing these statements, Gribkov added: "We did not repeat an Afghan variant on the banks of the Vistula. The Brezhnev Doctrine would not work in Poland."197
Jaruzelski was now seen by all sides as a key player. But where did his loyalties lie? As a wartime exile to Siberia, where his family perished and he worked in a labour camp, he might have stressed his Polish patriotism. Yet he seemed determined to stress his loyalty to the Soviet Union. Trained there, he rose to become the youngest general in the Warsaw Pact. When replacing Kania as Party leader, while remaining Prime Minister and Minister of Defence. he told Brezhnev (18 October) that he accepted the post "as a communist and a soldier." Any reference to patriotic duty was absent. Such ambivalence was further highlighted in the days immediately before the "state of war" (13 December), when he made further "phone calls to the Kremlin, requesting Soviet intervention: 'Can we count on assistance of a military sort from the USSR?" Andropov replied: "At this stage, there can be no consideration at all of sending troops." ${ }^{198}$ Despite the rebuttal of his requests, Jaruzelski presented his 'state of war' as a "lesser evil" to avert invasion.

Further ambiguity comes from a Polish Ministry of Interior memo (25 November). which rehearses possible outcomes of the "state of war." In this "secret, for special use, single copy" document, Scenario 3 was a general strike. "Workers take to the streets, there are public demonstrations and attacks on Party and government buildings, on the citizen's militia and others. It leads to a sharp intervention of militia forces and the army. The assistance of Warsaw Pact forces is not ruled out." ${ }^{199}$

\footnotetext{
${ }^{196}$ RGANI, Fond 2, opis’ 3, delo 568, “Plenum TsK KPSS 18 Noyabr’ 1981 g.”, pp. 125-145.

${ }^{197}$ A.I. Gribkov, 'Doketrina Brezhneva' i... p. 57 and extended discussion in: Wejda nie wejdq..., pp. 145-204.

${ }^{198}$ M. Kramer, The Anoshkin Notebook on the Polish Crisis, December 1981, “CWIHP Bulletin” 1998, Issue 11, 11 December, pp. $19,21$.

${ }^{199}$ P. Machcewicz, The Assistance of Warsaw Pact Forces Is Not Ruled Out, “CWIHP Bulletin” 1998, Issue 11, 11 December, pp. $40-42$.
} 
This may simply have been a 'worst case' analysis, but it underlines that, whatever the Soviet leadership said in public - and in their carefully conducted and formally transcribed Politburo discussions - the military option was available, if only as a last resort.

Jaruzelski himself tried to explain his questioning of Kremlin leaders as "a way to check their inclinations for intervention. In a way, it was a mutual testing, a mutual game. We kept getting the impression they were keeping some cards hidden." He referred to a further attempt to telephone Brezhnev the day before the 'state of war'. Suslov came to the receiver and was asked whether it would be a purely internal affair. Suslov replied: "But you have always said you can manage by yourselves". This was not fully reassuring to Jaruzelski who recalled "In Bratislava in August 1968 there were even kisses, yet, as we all know, everything ended very quickly."200

Siwicki assured a meeting of Warsaw Pact Defence Ministers in Moscow (1-4 December) that "political morale within the Polish military is satisfactory. Consequently, the Polish People's Army (LWP) successfully resists the attacks of the class enemy and plays an essential stabilising role in the life of our country, despite the fact that conscripts entering its ranks, who had come under the negative influence of Solidarity, preserved their own ideological and political character." In reply, the Soviet, East German and Bulgarian Defence Ministers "expressed alarm” about Polish developments. At Jaruzelski's request, a final communiqué was drafted to show his population that its Warsaw Pact allies were deeply concerned about developments in Poland, especially those fomented by the West. The agreed statement denounced "subversive activities of anti-socialist forces, behind whom stand aggressive imperialist circles" which had "a direct impact on the fulfilment of the allied obligations of the armed forces of the Warsaw Pact member-states." In its "battle to bring the country out of its crisis' the Polish Party and nation could 'rely completely on the support of the socialist states." 201

Some Western analysts argue that the "noninvasion" of Poland - rather than the "self-invasion" of the "state of war" - marked the end of the Brezhnev Doctrine. Matthew J. Ouimet states that "Quietly, almost imperceptibly, the Brezhnev Doctrine was slipping into history". He dates this from June 1981. What remained thereafter was "an empty shell reliant on surviving fears to maintain stability in bloc affairs." 202 He quotes his interview with Gribkov in support of such a view. "1989? No it died earlier. It died in 1980-81. The fact that we didn't send troops into Poland shows that the Brezhnev Doctrinethat is, resolving problems by force- was dead." 203 Yet Gribkov's own account does not disguise preparations for an invasion. "Did there exist a real plan to send Soviet troops into Poland? Yes, there was such a plan. More than that,

\footnotetext{
${ }^{200}$ W. Jaruzelski, Commentary, “CWIHP Bulletin” 1998, Issue 11, 11 December, p. 35.

201 "Progress and Outcome of the 14th Meeting of the Defence Ministers Committee", appended to A. Paczkowski and A. Werblan, On the Decision to introduce martial law in Poland. Two historians report to the Commission on Constitutional Oversight of the Polish Sejm, "CWIHP Working Paper" 1997, No. 21, pp. 34-36.

${ }^{202}$ M.J. Ouimet, Conclusion [in:] idem, The Rise and Fall of the Brezhnev Doctrine in Soviet Foreign Policy, Chapel Hill 2003 , p. 249.

${ }^{203}$ M.J. Ouimet, The Rise and..., p. 242.
} 
reconnaissance of entry routes and places to concentrate forces was done with the active participation of Polish representatives." 204

Wilfried Loth reviews the 1968 invasion. Though seen in the West "as the expression of a special Brezhnev Doctrine of limited sovereignty. In actuality, the decision in favour of intervention was less a strengthening of the Soviet Union's hegemony over the states of the Warsaw Pact than a victory of the Communist apparatus over politics." It sounded the death-knell of de-Stalinisation and left communist reform movements "high and dry." 205 He considers that Soviet leaders had developed a growing sense of proportion after "12 years of Western détente." This had become "so important that the Soviet leadership did not wish to undermine it unnecessarily by military intervention in Poland." Hence by 1980 , in his view, the Brezhnev Doctrine had become "an obsolete mechanism for the Soviet Union to exert its power and influence in Eastern Europe." ${ }^{206}$ However, super-power détente had already collapsed by the mid-seventies. Arms reduction talks were on hold and SALT 2 remained un-ratified by the US Senate. The first Reagan administration's more strident denunciation of the 'empire of evil' and the "Soviet threat," also limits this interpretation.

We cannot know for sure that Moscow would have intervened militarily had "the state of war" not been enacted, or had failed, but to assert that they would not have done so seems at best unproven. Loth's wider arguments for "Soviet restraint" suggest that Moscow had learned the limits of the use of force from Czechoslovakia and most recently Afghanistan. Andropov had visited Kabul and realised that Soviet forces would have to stay there indefinitely. Ustinov had concurred: "I think about a year will be needed, maybe even eighteen months until the situation in Afghanistan is stabilised and before we can even contemplate a withdrawal of forces". 207

Vojtech Mastny agrees that the Kremlin had become more aware of constraints on military capacity. "Gone was the superficial Brezhnevian belief in the country's irresistible global ascendancy: his more sombre colleagues and later successors knew better, and acted accordingly." Mastny sees the "non-invasion" of December 1980 as a deferment: intervention was "not called off but conditionally postponed.” Unlike previous crises, there was the option of a Polish leadership 'forcibly suppressing the anti-communist movement' on their own. The Polish crisis thus reveals how "Soviet capacity to hold the empire together by the old crude methods progressively lapsed." Even so, replacement of Party by military rule in Poland did not make the Kremlin comfortable. "Having seen the limitations of the military power they had so prodigiously accumulated, they were losing confidence in it." ${ }^{208}$ These are prescient accounts of the eventual withdrawal from Eastern Europe almost a decade later.

\footnotetext{
${ }^{204}$ A.I. Gribkov, 'Doktrina Brez̧hneva' i..., p. 55.

${ }^{205}$ W. Loth, Overcoming the Cold War. A History of Détente, 1950-1991, London 2002, p. 99.

${ }^{206}$ W. Loth, Moscow, Prague and Warsaw: Overcoming the Brezhnev Doctrine, "Cold War History" 2001, Vol. 1 (2), p. 112.

${ }^{207}$ CPSU Politburo, 7 February 1980, “CWIHP Bulletin” 1996, Vol. 8/9 Winter, p. 166.

${ }^{208}$ V. Mastny, The Soviet Non-Invasion of Poland in 1980-1981 and the End of the Cold War, "Europe-Asia Studies" 1999 , Vol. 51 (2), p. 207.
} 
Euro-communists were outraged by the "state of war." As the Soviets fulminated against "right-wing extremists in Solidarity", the Italian Communist Party (PCI) celebrated "the success of Solidarity as living proof of a tumultuous breakthrough of the Polish working-class onto the political arena - an event by which space was opened up for their intervention in the management of factories, the economy and the state." The dramatic outcome, martial law, had shown "the damage done by adopting a single model the Soviet-type model - in the countries of Eastern Europe; as regards both the economy and, especially, the political system." ${ }^{209}$ In a sharp exchange with Moscow, the PCI affirmed "the working class and the people are the only force which can legitimise power in Poland as socialist. Military intervention against them cannot be a defence of socialism." ${ }^{210}$

Some Moscow analysts offered more objective interpretations of the Polish crisis. Though overlooked at the time, they have future significance as an intellectual origin of the rethinking that informs the Gorbachev years. Thus N.I. Bukharin - unrelated to his Old Bolshevik namesake - prepared a detailed report for the Institute of the Economy of the World Socialist System (IEMSS), delivered to the Central Committee in June 1981, but unpublished. Origins of the Polish crisis are not seen as Western at all. On the contrary, far from ensnaring Poland in debt, Western credits obtained since the early Seventies were on generous terms and often re- scheduled. The problem was the squandering of such investment by an over-centralised bureaucracy, obsessed by giant projects (gigantomania) and neglecting public needs. Consequent shortages of housing, medicines and even food, had increased social tensions. Black market channels flourished and the Party nomenklatura - largely sheltered from shortages - became the visible face of corruption in public life. ${ }^{211}$ In spring 1981, Poland was approaching Lenin's notion of a "revolutionary situation". The report advocated a conciliatory response from Moscow, avoiding repression, and concluded that "if reforms are not undertaken soon, it will mean sthe death of socialism."”

Another Russian observer of the Polish scene was the philosopher A. Tsipko, a researcher at the Bogomolov Institute, which provided international reports for the Central Committee and Politburo. Their materials, studied by Gorbachev as incipient Party leader, showed a sharp disparity between low living standards in the Soviet Union and those of Eastern Europe. The costs of empire were too high. Tsipko recalls that the mood amongst the hierarchy in the International Department of the Central Committee "did not at all differ from the mood in the Academy of Sciences or in the humanities institutes... it was clear that only a complete hypocrite could believe in the supremacy of socialism over capitalism. It was also clear that the socialist experiment had suffered defeat." 212 Although not admitting so openly, they had become social-democrats by

\footnotetext{
${ }^{209}$ PCI Resolution, “l’Unita” 29 December 1981.

${ }^{210}$ Editorial, "Pravda" 24 January 1982; A Reply to Pravda, "l’Unita" 26 January 1982.

${ }^{211}$ N.I. Bukharin et al, O prichinakh i suchnosti krisia 1980 g. v PRN, Moscow 1981.

${ }^{212}$ M.J. Ouimet, The Rise and..., pp. 253-254.
} 
1985, "as had the ruling parties in Poland and Hungary.”

During Gorbachev's ascendancy, such alternative thinking moved slowly from behind the closed doors of research institutes into the policy arena. Gorbachev's chairmanship of the Politburo's Polish Commission (from 1984) contrasted with the former dogmatism of his predecessors Suslov, Andropov and Chernenko. He now allowed members of IEMSS and other academic institutes to challenge accepted orthodoxies and introduce reformist ideas. However, his open reaction to the boldest suggestions was reportedly sceptical. ${ }^{213}$ Thus when the Politburo discussed Poland on 26 April 1984, he stated the country still looked unstable, particularly in the state's relations with the working class. The fact of mass resignations from the Party, including 1,200 from the Gdańsk Shipyard, showed that the PZPR was neglecting its provincial base. He thought Jaruzelski should clearly understand that "Poland must not have a pluralist system of government". ${ }^{214}$

The near consensus in the West that SovietEast European relations were immutable had two prescient exceptions. Both came in academic addresses during the spring and summer of 1982. Zbigniew Pełczyński told his Oxford audience "I do not believe that the majority of Polish Communists have the will to govern permanently against the determined opposition of their compatriots. They prefer authority to coercion. As for the Soviet Union, more than anything else it needs stability in East-Central Europe so it can tackle its own economic problems and search for a nuclear modus vivendi with the United States." 215 Rett Ludwikowski asked his Stanford audience whether the crisis of communism would begin in Poland, answering that it already had. "The idea of Solidarity is more than a Polish curiosity". However, Western responses were crucial. "Followers of the Brezhnev Doctrine understand perfectly the principles of Antonio Gramsci, who argued that any subversion of a political system, any overthrow of a government, must be preceded by a refashioning of the attitudes and ideas of the soon-to-be-conquered society. Political power must be preceded by ideological power." ${ }^{216}$ Western sanctions in response to the Afghan invasion and the Polish crackdown had been symbolic and uncoordinated. He advocated that they should be otherwise.

\section{Part Three: Annulment}

In Gorbachev's subsequent account, he summoned a meeting of East European leaders immediately following Chernenko's funeral and told them "we will respect your sovereignty, your independence.” In consequence, they would have to shoulder "all the responsibility for the policies that you carry out in your countries. We will be friends. We will be partners. Our relationship will be built on this basis.' He had noted a mixed reaction to these statements at the time. Since his predecessors had all said the same, without

\footnotetext{
${ }^{213}$ R.D. English, Russia and the Idea of the West. Gorbachev, Intellectuals, and the End of the Cold War, New York 2000, n. 57, p. 325.

${ }^{214}$ Stenogram in: W.G. Pawłow, Generat Pawtow: bytem rezydentem KGB w Polsce, Warszawa 1994, p. 379.

215 Z.A. Pelczynski, Poland: the Road from Communism, Oxford 1983, p. 31.

${ }^{216}$ R.R. Ludwikowski, Will the Crisis of Communism Begin in Poland?, Stanford 1983, pp. 20-21.
} 
carrying it out in practice, a certain scepticism was inevitable. ${ }^{217}$ However, he told his Washington audience (7 December 1999) "I never retreated from the rule of respecting sovereignty, independence, and not interfering in internal affairs. There were moments when they actually appealed to us - some of them appealed to us to intervene. But our ambassadors told them what needed to be told. So that the Brezhnev Doctrine, or the doctrine of limited sovereignty, was ended even before Chernenko was buried."218 This retrospective claim is not confirmed by his report to colleagues at the time, though Gorbachev did warm to Jaruzelski "who said directly we should meet much more often, maybe even without preparing for such meetings, without reading speeches out to each other." ${ }^{219}$

Soviet leaders had learned from past succession crises. During the post-Brezhnev interregnum, they issued unequivocal warnings to Eastern Europeans to stay in line. These predominated bilaterally and at the Comecon summit (June 1984) and at the Warsaw Pact meeting (26 April 1985), just after Gorbachev's appointment was announced. They culminated in an authoritative statement by "Vladimirov" in Pravda which set out a formidable catalogue of Soviet admonitions to Eastern European leaders. The main points were:

1. Defend the "fundamental principles of socialist economic management." Protect socialist ownership against revisionist attempts to extend the private sector, and central planning against bourgeois apologists who allege the socialist system is unable to develop in a dynamic way.

2. Strengthen Marxist-Leninist theory. The laws of socialist construction have general validity and cannot be regarded either as an abstract concept or a historical legacy "correct only for some time in the past".

3. National models of socialism championed by the West and nationalism continue to be the chief hope of the class enemy. Western propaganda tries to cultivate the worship of its own civilisation and to exaggerate "injustices" or "black spots" in the history of Soviet relations with a number of fraternal countries.

4. Small countries have no special role in international relations. Efforts of others to mediate between the super-powers are meaningless since the foreign policies of the USSR and "the Marxist-Leninist nucleus of world socialism" are identical. ${ }^{220}$

This last point evidently referred to Hungarian and East German efforts to achieve more scope for manoeuvre in European politics. Further foreign policy insubordination from Romania was also precluded.

Seweryn Bialer, who left Poland in 1956, argued that this article, emanating from the Central Committee Secretariat, "clearly embodied Gorbachev's own views". He characterised this as an all-out hard-line policy towards Eastern Europe. It included insistence on political

\footnotetext{
${ }^{217} 2$ M. Gorbachev, Memoirs, London 1996.

${ }^{218}$ Cited by M.J. Ouimet, The Rise and..., pp. 254-255.

${ }^{219}$ NSA, Volkogonov Collection, Reel 17, Container 25. "Conference with Central Committee Secretaries”, Moscow, 15 March 1985.

${ }^{220}$ Vladimirov, "Pravda" 21 June 1985.
} 
orthodoxy, particularly in Hungary and Poland, crackdowns on dissent, a siege mentality and anti-Western propaganda. ${ }^{221}$ In fact, we now know that Gorbachev railed against the article at the next Politburo and telephoned Kadar and Honecker to tell them "this article does not reflect the views of the Soviet leadership". ${ }^{222}$ Indeed, Gorbachev was assembling a new foreign policy team which explicitly rejected the "Vladimirov" view and sought a new, more equal, relationship with Eastern Europe.

One unexpected outcome of 1968 had been the return to Moscow of Russian intellectuals employed in Prague by the International Department of the Central Committee to edit the journal Problems of Peace and Socialism. A key figure was Anatoly Chernyaev, who became a confidant and close advisor of Gorbachev. He recalls the Prague Spring as "a milieu favourable to freedom of thought and behaviour" which led a majority of his Russian colleagues to alter their outlook. "I daresay that none us believed in communism any more. In our circle that would have been absurd, showing either cowardly hypocrisy or mental deficiency". ${ }^{223}$ Georgi Arbatov agreed: "These people helped build an intellectual bridge from the Twentieth Congress (1956) to perestroika, over the chasm of stagnation' and served as 'a barricade against the counter-attacks of Stalinism."224

Following the "Vladimirov" affair, personnel changes were made in its place of authorship. New head of the Central Committee's Socialist Countries Department was Vadim Medve- dev, known to have favoured reform during the early 1960's debates and considerably more enlightened than his 75-year old predecessor, Rusakov. Moreover, "Vladimirov" himself (Oleg Rakhmanin) was joined as joint deputy head of the Department by Georgy Shakhnazarov, the same age (62), but unlike Rakhmanin an innovative thinker within the Soviet establishment and higher education. As Ron Hill noted in his prescient study of Shakhnazarov and others, such scholars had begun to draw distinctions between public and private interests, implying they do not always coincide. Conflicts of interest could arise between different sections of the economy, and between local and national interests. Bureaucrats could develop interests of their own. ${ }^{225}$ Admitting such distinctions provided space for a new approach to politics and international relations.

Shakhnazarov and Medvedev prepared a critical report by Gorbachev on Soviet relations with Eastern Europe. It stated bluntly that Moscow was regarded as a "conservative power that hinders reform." Warsaw Pact integration was far behind that attained in Western Europe and economic relations with Eastern Europe were equally backward, amounting to little more than "commodity exchange." The report called for a "genuine turning-point" in relations with Eastern European allies. Moscow still had a leading role in the socialist world but should use the force of example rather than the example of force. Instead of issuing directives, the CPSU should take "constructive initiatives to deepen

\footnotetext{
${ }^{221}$ S. Bialer, The Soviet paradox: external expansion, internal decline, London 1986.

${ }^{222}$ NSA, Chernyaev Diary for 1985, 5 July.

223 A. Chernyaev, Moia Zhizn' i Moye Vremia, Moscow 1995, pp. 234-245.

${ }^{224}$ G. Arbatov, The System: An Insider's Life in Soviet Politics, New York 1992, p. 76.

${ }^{225}$ R. Hill, Soviet politics, political science and reform, London 1980.
} 
collaboration." Perestroika of relations with socialist countries was "a matter of exceptional importance". ${ }^{226}$ Despite this upbeat message, it seems that Gorbachev had come to realise that hegemony over Eastern Europe was not a demonstration of Soviet power, but had become its opposite.

His speech to the next Polish Party Congress was a model of diplomacy. He praised Jaruzelski as an "energetic and political perspicacious leader" who was tackling Poland's complex problems in the interests of "the whole nation". Contrasting the imperialist machinations of the West, imposing economic 'sanctions', he promised that Soviet people would give Poland "all the help we can." 227 Returning to Moscow, he told the Politburo that relations with socialist countries was now at a new stage. Old methods, used in Czechoslovakia and Hungary, had gone forever. ${ }^{228} \mathrm{~A}$ week later, he told the Politburo that a jointly-authored volume would provide a "history of Polish-Russian and Russo-Polish relations." He added that Katyń, the mass murder of Polish officers in spring 1940, would be investigated. ${ }^{229}$

When Jaruzelski visited Moscow (21 April 1987), Gorbachev spoke quite openly about barriers to political reform. An indecisive Party avoided hard decisions and "from being the vanguard, can become an obstacle." ${ }^{230}$ His grow- ing impatience with the PZPR, ${ }^{231}$ resembles that of Gorbachev with the CPSU. Both come to realise that, far from exercising leadership, the communist establishments had become the main barrier to political change. Faced with intractable economic problems in Poland, the nomenklatura had retreated into its shell. No longer true believers - like the loyal war-time and first post-war generation - the new rulers and beneficiaries cared nothing for communism. All that mattered was to protect their own. Provided that could be secured, they cared little about the crumbling of the system. ${ }^{232}$

Gorbachev's “New Thinking” transformed the context in which Solidarity, and other peaceful movements of civilian resistance, could operate. Moscow encouraged East European leaders to reach new accommodations with their own societies, without the threat of Soviet intervention. Most held back and resisted change but Jaruzelski understood the new opportunities. By 1988, hitherto unthinkable political changes began to be contemplated. Given that the Party apparatus came to be seen by both Polish and Soviet leaders as the main political problem, they started to experiment with alternative institutions.

Rather than recognise Solidarity, however, the Polish authorities attempted a new strategy: co-optation. "Individuals representing opinion-

\footnotetext{
${ }^{226}$ Archive of the Gorbachev Foundation, Fond 5. Gorbachev to the Politburo, 26 June 1986.

${ }^{227}$ Otvechaya na vuizov vremeni, Vneshnyaya politika perestroiki: dokumental'nie svidetel'stva, Tenth Congress PZPR, Warsaw, 30 June 1986, p. 521.

${ }^{228}$ Otvechaya na viizov vremeni, Politburo, 3 July 1986, pp. 521-522.

${ }^{229}$ Otvechaya na vuizov vremeni, Politburo, 11 July 1986, p. 522.

${ }^{230}$ Otvechaya na vuizov vremeni, Conversation with Jaruzelski, 21 April 1987, pp 528-530.

${ }^{231}$ AAN, 237 /V/83, Secretariat 4 April 1987, pp 48-54.

${ }^{232}$ M. Kula, Wychodzenie po angielsku, „Krytyka. Kwartalnik Polityczny” 1991, No. 34/35.
} 
making circles, who do not have contact with the highest state authorities" were invited to join a new Consultative Council. Its role would be to advise Jaruzelski as Head of State. After lively debate, especially amongst the Club of Catholic Intellectuals, most of those approached declined. The Consultative Council's bi-monthly meetings, on general issues, was described by one participant as "a kind of discussion club." 233 Since such initiatives offered a mere "consultative democracy" they led to a "failure of authoritarian change."234

Gorbachev was pressing for more radical changes behind the scenes, even though he did not anticipate the dramatic outcome that he himself would help to bring about. His thinking lead to re-examination of Lenin's legacy. Hitherto it was used simply as a selective source-book for convenient quotations, but Gorbachev realises that Lenin took theory seriously and that to a great extent his political thought preceded action. But "what was Leninism nowadays and how did it relate to Stalinism?" He answers: "Stalin is not just 1937. It is a system: system in everything from economics to peoples' consciousness."236 As his attention turns to the "last opposition" to Stalin in the late Twenties, he focuses on Bukharin as the advocate of continuing the NEP to achieve industrialisation peacefully, by gradual means. ${ }^{237}$ Socialism had to be a living ideology, with a creative methodology. "Look how carefully and delicately Bukharin approached every question. He was meticulous about being true to socialism." ${ }^{238}$ Bukharin is duly rehabilitated and his oeuvres restored to the Marxist canon. Gorbachev reads his Western biography in translation. $^{239}$

Despite this research, the relevance of Leninism remains elusive. Gorbachev privately exclaims: We say “return to Lenin's image of socialism." Yes! But what does it mean in today's circumstances? We are cleansing it from Stalinshchina, Brezhnevshchina. There's a lot more work here. But this is negativist work. What should construction be? There should be a legal, socialist state. It's a major work problem. ${ }^{240}$

Chernyaev summarises Gorbachev's view: "the regime which was constructed over seventy years has to break down. Only then will our society begin to rebuild itself anew. No dogmas of the past are acceptable, even if they are »Lenin's! «". ${ }^{241}$

Meeting the Czechoslovak leader, Jakes, Gorbachev commented on the re-activation of leaders of the "Prague Spring." Dubček had given an interview to l'Unita which compared 1968

\footnotetext{
${ }^{233}$ A. Tymowski, Widziane z. wewnatrz, „Polityka”, 20 June 1987.

${ }^{234}$ A. Gerrits, The Failure of Authoritarian Change. Reform, Opposition and Geo-Politics in Poland in the 1980s, Dartmouth 1990.

235 See N. Harding, Lenin's Political Thought, Vol 1. Theory and Practice in the Democratic Revolution, London 1977); idem, Vol. 2

Theory and Practice in the Socialist revolution, London 1981.

${ }^{236}$ NSA, Chernyaev Diary for 1987, 5 July.

${ }^{237}$ The Ideas of Nikolai Bukharin, (ed.) A. Kemp-Welch, Oxford 1991.

${ }^{238}$ NSA, Chernyaev Diary for 1987, 17 September.

${ }^{239}$ S.F. Cohen, Bukharin and the Bolshevik Revolution: A Political Biography, 1888-1938, New York 1975.

${ }^{240}$ NSA, Chernyaev Diary for 1988, 24 April.

${ }^{241}$ NSA, Chernyaev Diary for 1988, 31 December.
} 
to current developments in Soviet politics. The same parallel was being drawn by "my old acquaintance Zdeněk Mlynář”, with whom Gorbachev had studied law at Moscow University in the early 1950's. ${ }^{242}$

On his visit to Yugoslavia in March 1988 he assured his hosts that "diversity of forms of socialism is not a sign of weakness but of strength". Socialism was not a closed system following "a single model of society". "No-one can pretend to a monopoly in deciding all social problems". But he noted that reforms were proceeding at different speed across the socialist bloc. Hungary and Poland had started on a reform path, while Romania and the DDR had not, and were critical of the current Soviet leadership. Soviet perestroika thus accelerated the process of differentiation between them. ${ }^{243}$

Perestroika accelerated the reform process in Poland by depriving conservatives in the Party apparatus of a crucial argument against political change. They could no longer claim that change was precluded by geo-politics and "the (Soviet) neighbour". However, it was also true that removing the Soviet "bogey" would make it harder to contain domestic pressures for reform. Jaruzelski's trojka of advisors considered this in a position paper for his eyes only. They noted that Soviet reforms removed an important "safety valve" for communist power. ${ }^{244}$ Rakowski, the "man for all seasons" of Polish politics, sent a further memo to Jaruzelski asking what would happen if there was a further explosion in Poland. If the authorities declared it might lead to "someone's intervention", that "someone", considering their own interests, could refuse to intervene. ${ }^{245}$

The investigation of "blank pages" in SovietPolish relations gathered pace. They now included reconsideration of the Ribbentrop-Molotov Pact and the subsequent invasions of Poland. The secret protocol which facilitated them would also be acknowledged. ${ }^{246}$ This was seen as a necessary preliminary to Gorbachev's planned visit to Poland. As the dynamic of perestroika accelerated, including reforms in Hungary and protest rumblings in the Baltic republics, there came a sense that Poland was being left behind. On the surface, political discourse remained courteous. When Prime Minister Messner visited Moscow, Gorbachev was a model of urbanity "I want to emphasise that there are no secrets amongst friends. What attitude to take towards perestroika is a sovereign decision of each Party. No-one can force it down their throat. But we do of course see that we are giving a certain impulse to our friends." 247

During Gorbachev's Polish visit (11-17 July) Medvedev noted a "unison with Soviet perestroi$k a$ " and "the beginnings of achieving full mutual understandings". This went beyond mere diplomatic politeness. Gorbachev sought to speed up a Polish reform process that had thus far been very slow. He raised questions such as "relations with the oppositions" and "the influence exerted

\footnotetext{
${ }^{242}$ Otvechaya na vuizov vremeni, Conversation with Miloš Jakeš, Kremlin, 11 January 1988, pp. 542-543.

${ }^{243}$ V.A. Medvedev, Razpad. Kak on nazreval v 'mirovoi systeme sotsializma', Moscow 1994, pp. 33-34.

244 A. Paczkowski, Nastroje przed bitwa, „Zeszyty Historyczne” 1992, No. 100.

${ }^{245}$ M. Rakowski, Jak to się stało, Warszawa 1991, p. 101.

${ }^{246}$ Otvechaya na vuizov vremeni, Politburo, 5 May 1988, On the secret Soviet-German Protocols of 1939, pp. 550-553.

${ }^{247}$ Archive of the Gorbachev Foundation (AGF), Fond No.1, opis' No. 1, 6 April 1988.
} 
on various parts of the social structure by Solidarity." 248 In sharp contrast to the Brezhnev period, these references were not derogatory. Gorbachev stated "there is no substitute for dialogue with the nation, as a method of public opinion research." He referred to "socialist renewal" in Poland and perestroika as twins. ${ }^{249}$

Jaruzelski told Gorbachev of two boundaries that could not be crossed. "We will not permit trade union pluralism, nor will we allow the formation of opposition parties." 250 Unlike the Polish text, the Russian transcript continues: "The West is urging us to recognise Wałęsa. They say that M S Gorbachev had telephoned Sakharov (in internal exile in the city of Gorky). But Sakharov is not Wałęsa.” Whilst he thought it might be conceivable to give Wałęsa a Parliamentary seat or some consultative position, this treatment could not be extended to the leader of Rural Solidarity (J. Kula) whose organisation no longer existed. Jaruzelski conceded that the same could not be said of Wałęsa's. ${ }^{251}$

Underlying Soviet concerns was the dramatic increase of public unrest in Poland. Students demonstrated on the twentieth anniversary of the March 1968 events. Then in late April, the key player in the Polish drama, subjugated by years of martial law and economic deprivation, re-entered the political stage. First in Bydgoszcz, transport workers brought bus and tram services to a halt. The Lenin Steelworks in Krakow began a ten-day strike next day. Protests soon spread to the Baltic and Silesia. ${ }^{252}$

This raised what Mark Kramer calls the 'Khrushchev Dilemma': "If a comparable crisis (to 1956) had erupted, the pressure for Soviet military intervention would have been enormous, just as it was on Khrushchev. ${ }^{253}$ Gorbachev's options would have been stark: military intervention would destroy the East-West collaboration which Gorbachev had so carefully constructed. To decline to use force would give domestic opponents an ideal pretext to move against him. Finally, were rapid political change in Poland or elsewhere in the "bloc" to break down into civil strife, populism or demagogic dictatorship, the fate of Soviet reformers would be sealed. ${ }^{254}$

Bold new measures were needed to calm Poland down. Steps which Jaruzelski had so recently deemed unthinkable became imperative when workers' strikes resumed, at the Manifest Lipcowy coalmine in Jastrzębie (15 August). While the Ministry of Interior was told to plan for a state of emergency, including the use of the Security Service to arrest oppositionists, ${ }^{255}$ the Politburo now opened channels of communication with them.

\footnotetext{
${ }^{248}$ V.A. Medvedev, Razpad. Kak on..., pp. 82-88.

${ }^{249}$ Ibidem, pp. 108-117.

${ }^{250}$ S. Perzkowski (A. Paczkowski), Tajne dokumenty Biura Politycznego i Sekretariatu KC. Ostatni rok wtadzy 1988-1989, Londyn 1994, p. 8.

${ }^{251}$ AGF, Fond No.1, opis' No.1, 14 July 1988.

${ }^{252}$ A. Dudek, T. Marszalkowski, Walki uliçne w PRL, 1956-1989, Kraków 1999, pp. 372-379.

${ }^{253}$ M. Kramer, Gorbachev and the demise of east European communism [in:] Reinterpreting the End of the Cold War. Issues, interpretations, periodizations, eds. S. Pons, F. Romero, London 1994, pp 182-183.

${ }^{254}$ A. Walicki, Notes on Jaruzelski's Poland [in:] Crisis and Reform in Eastern Europe, eds. F. Feher, A. Arat, London 1991 , p. 382.

${ }^{255}$ L. Kowalski, KOK wobec opozycji politycznej i Kościoła w latach 80-tych, „Zeszyty Historyczne” 1995, No. 113, pp. $125-147$.
} 
The first intermediary Stelmachowski signalled the readiness of the former Solidarity for talks with government, but only with participation of "the Electrician" (Wałęsa). ${ }^{256}$ The Party's envoy to the Church told Episcopal Secretary (25 August) that radical political reform was possible but trade union pluralism was not. When Ciosek justified this by reference to the power unions had achieved in 1981, the Orszulik replied "there is a great difference in time and circumstance between years 1981 and 1988. Then there was the Brezhnev Doctrine'. The Party emissary Barcikowski could only respond: "You think the Brezhnev Doctrine is no longer operative? Gorbachev is making perestroika but against him is a whole army!"257

Dashichev describes the process by which Gorbachev and Shevardnadze "were gradually succeeding in forging a realistic foreign policy, free of the dogmas and burdens of the Stalinist era." 258 Gorbachev renounced the principle of "paternalistic relations" between the Soviet Union and Eastern Europe, and stated the Warsaw Pact countries accepted public international law as the basis of their relations. Gorbachev told Defence Ministers (7 July) "Each Party is responsible for its own affairs and fulfils its tasks on its own. There will be no toleration of attempts not to respect each other, or to interfere with the domestic affairs of others". ${ }^{259}$ Expounding his notion of the "European House" (15 July), Gorbachev denied a hidden agenda of dissolving NATO and "excommunicating" the United States from Europe. He envisaged Europe as a special continent where "a unique structure is being erected, one of interaction between two social systems." There would not be a fusion of the two, or one swallowing up the other: "In this connection, we repudiate any argument about 'overcoming the legacy of Yalta'. We call for respect for national sovereignty in the European community. Of combined territorial-political realities created by the people in their choice of social structure". ${ }^{260}$

The Polish Interior Minister's appearance on television (26 August) was a revelation. Three days earlier Kiszczak had been threatening extraordinary measures. Now he was a model of calm. He wished to convene a Round Table urgently, with no preconditions and no participants excluded other than those who rejected the legal and constitutional order. ${ }^{261}$ Simultaneously, the Soviet newspaper Literaturnaya Gazeta requested an interview with Wałęsa "as representing a wide circle of public opinion." It wished to ask about the present situation in Poland and the role of opposition. ${ }^{262}$ The request was rebuffed through diplomatic channels. However, Wałęsa held

\footnotetext{
${ }^{256}$ A. Stelmachowski, Ksztaltowanie sie ustroju 111 Rzeczpospolitej, Warszawa 1998, p. 42.

257 Rozmowy z.władzami PRL. Arcybiskup Dabrowski, ed. P. Raina, Warszawa 1995, p. 256.

${ }^{258}$ V. Dashichev, On the Road to German Reunification: A View from Moscow [in:] Soviet Foreign Policy 1917-1991, ed. G. Gorodetsky, London 1994, pp. 174-175.

${ }^{259}$ Committee of Ministers of Defence, Moscow [in:] A Cardboard Castle? An Inside History of the Warsaw Pact, 1955-1991, eds. V. Mastny and M. Byrne, Washington / Zurich 2005, p. 605.

${ }^{260}$ Political Consultative Committee, Warsaw [in:] A Cardboard Castle?..., p. 608.

261 Okragły stót, (ed.) K. Dubiński, Warszawa 1999, p. 35.

${ }^{262}$ AGF, Fond No. 1, opis' No. 1, 25 August 1988.
} 
a historic and symbolic meeting with Kiszczak on 31 August, the eighth anniversary of the Gdańsk Agreement.

Shakhnazarov's paper for the Politburo (6 October) noted that some countries had followed perestroika, leading to 'socialism of a new quality'. Others had gone even further with farreaching reforms. By contrast, the DDR and Romania still did not see the need for change. In reality, all the countries needed fundamental change "though we cannot say this publically, lest they accuse us if trying to impose perestroika on our friends". Even the most advanced showed alarming tendencies, including problems of public disorder in Poland, and activities of the Chartists in Czechoslovakia. He concluded: "it clearly follows that in future the possibility of extinguishing (gasit') crisis situations by force must be completely ruled out."263

When Polish leader Czyrek visited Moscow Gorbachev asked him whether the proposed Round Table was simply a tactical manoeuvre from which little could be expected. Was it an adequate response to the influence of the opposition? On the choice of a new Prime Minister, Gorbachev though Rakowski the best candidate, though he was perhaps an over-ambitious personality. ${ }^{264}$ When Rakowski himself arrived in Moscow, there was a meeting of minds. He explained that Poland was seeking to replace the "commandadministrative method" of running the economy. Gorbachev commented "Exactly like us".

Turning to domestic politics, Rakowski attributed Solidarity's recent revival to Western funding which had allowed "the frozen structure to reactivate itself". Despite this, the Party wanted a successful Round Table to create a new political situation. If "Wałęsa and his group" failed to take part, then the Party would achieve a success in the eyes of society. There had been many critics of this attempt at dialogue and "not everyone understands why we agreed to talk to Wałęsa", but there were great differences between 1981 and 1988. Then ministers went to Wałęsa for talks, now he had gone to the Ministry of Interior. A remaining obstacle, however, was his advisers. He noted that the Party too had "hardheads" opposed to any agreement. ${ }^{265}$

They then attempted a discussion of socialism. Gorbachev asked whether a post-Round Table Poland would remain "within the socialist system". Rakowski replied that only extremists were calling for a change of system. The Soviet leader wondered "what sort of socialism are we heading for?" "There was little practical experience of it. Rakowski mused: "We who favour reform are a bit uncertain- where are the boundaries?" Recalling that both Khrushchev and Brezhnev had attempted reforms, Gorbachev stated that "the structures of power remained unaltered. Lenin wanted socialism from the living creativity of the masses. But our socialism is distorted by bureaucracy." They agreed their shared objective was to "breathe life" into socialism, ${ }^{260}$ but there was little analysis of what a revived socialism might be. Equality was not mentioned, nor were worker participation, the right to strike, or self-managing systems.

\footnotetext{
${ }^{263}$ G. Shakhnazarov, Tsena Svobody: reformatsiya Gorbacheva glazami ego pomoshchnika, Moscow 1993, pp. 367-368.

264 AGF, Fond. No.1, opis’ No. 1, 23 September 1988.

${ }^{265}$ AGF, Fond. No.1, opis' No. 1, 21 October 1988.

${ }^{266}$ AGF, Fond. No.1, opis' No. 1, 21 October 1988.
} 
Rakowski's approach to Solidarity was confrontational. His government announced (31 October) that the Gdańsk Shipyard was to be closed "on economic grounds". Solidarity replied that he decision to close its birthplace was a "sinister and dangerous act" showing the government intended "to preserve and consolidate the Stalinist model of managing the economy." The Round Table was deferred indefinitely, and the furniture itself - which had been shown in construction on evening news bulletins - disappeared from view.

The stalemate was broken in an unexpected way. The Chairman of the official trade unions (OPZZ) suggested to his Politburo colleagues he hold a televised debate with Wałęsa. They reluctantly agreed. The US Ambassador in Warsaw advised Solidarity that simply by appearing on television, after being "un-person" for seven years, would guarantee Wałęsa victory. ${ }^{267}$ Indeed, "The Electrician", "Yesterday's opponent," "the post-Solidarity extremist," turned out to be a moderate and reasonable politician with constructive ideas for Poland's future. He referred to recent Soviet developments. "In 1980, in 1981, external conditions did not exist for the reforms Solidarity proposed: primarily as I once said - half-jokingly - because Brezhnev lived two years too long." Now, however, the position was reversed: "Over there, they are going further in their reforms. They are truly doing what Solidarity had been fighting for then and right up to the present day. That is why we shouldn't hamper perestroikas, but in our country - after all the experience we have had, on both sides - we should move further." However, the past had still to be overcome. "The Stalinist era isn't over yet ... And where did Stalin come from? He came because there was no political pluralism. We were the ones who built Stalin up, all of us, at that time. There were no controlling organisations, no pluralism, and he runs all this right up to today." 268

Jaruzelski realized the "unfortunate broadcast" had transformed the political landscape, but his Politburo had no idea how to regain the initiative. The Party was divided between those who "fear its disintegration, weakening its identity, its distinctive doctrinal base" and others - a distinct minority - who saw the opportunity for the Party to retain power, although exercised in a different way. ${ }^{269}$

Rakowski gave a grim prognosis to the Church hierarchy (4 January 1989). Economic reforms would proceed on the basis of a "genuine national agreement" in the spring but he gave no indication of how such consensus could be reached. He made no mention of Solidarity apart from advising Wałęsa to acknowledge that "Solidarity is not what it was in 1981." Gorbachev had for the first time made the socialist countries "entirely independent in furnishing our own house", but this did not mean all neighbours accepted perestroika. "The DDR says we have gone mad. Only Hungary understands us". Even within Poland, the reactions of the military, secret police and Party apparatus were unpredictable. ${ }^{270}$

\footnotetext{
${ }^{267}$ Polska 1986-1989: koniec systemu, Vol. 2 Dyskusje, Warszawa 2002, pp. 149-150.

${ }^{268}$ Polish TV, 30 November 1988, 19.00 GMT.

${ }^{269}$ Tajne dokumenty Biura..., p. 197.

${ }^{270}$ P. Raina, Rozmowy z. władzami..., pp. 329-330.
} 
Reporting to the Soviet Politburo, the IEMSS saw pressures for change in Eastern Europe as irresistible. To attempt to thwart them would be "tantamount to fighting the objective course of history". The use of force by Moscow would be disastrous, strengthening the conservative wing "in the upper echelons of power" and halting the reform process, making the domestic crises worse. "Intervention in the course of events on behalf of the conservative forces that are alienated from the people, will most evidently signal the end of perestroika, the crumbling of the trust of the world community [in our reforms]." However, Moscow would gain standing in the world community if change in Eastern Europe took place as the result of a conscious "revolution from above" rather than being forced by "revolution from below."

The Report saw three possible outcomes in Poland. The Party and Solidarity might reach a power-sharing agreement which, however precarious, started to diffuse social tensions. Alternatively, an extended deadlock would render the country ungovernable, turning Poland into the chronically "sick man of Europe." Finally, the collapse of talks would lead to a further explosion, probably in spring 1989, followed by a renewed martial law or an approximation of civil war - "Afghanistan in the middle of Europe." Even the first and most favourable outcome did not augur well for socialism. Poland was likely to evolve into a "classic bourgeois society of the Italian or Greek type.”271
At the crucial Polish Plenum, which sanctioned the Round Table, its opponents boasted of their support in Moscow. When their "bluff" was called by asking them to name their Soviet backers, the Party "concrete" (beton) refused to do so. In reality, they had none. ${ }^{272}$ Asked by a Solidarity intermediary before the Round Table: "What are the limits to the changes the Soviets are willing to accept in Poland?" Jaruzelski replied: “I don't know myself. Let's discover them together". ${ }^{273}$ Unbeknown to him, this discussion had already taken place in Moscow.

A senior foreign policy advisor, V. Zagladin sent Gorbachev a secret memo (24 January) on "a delicate and complicated question that could acquire great significance for us". This was the need to review Soviet obligations "regarding the provision of military assistance to foreign states in extreme circumstances." "At some stage in the further development of the international situation, especially in connection with regional conflicts, circumstances might compel us to take actions that could halt and even reverse what has already been achieved, what is being achieved, and what might be achieved in the future in the drive to restructure the entire system of international relations." He noted that NATO and the Warsaw Pact both had precise obligations for military assistance to other countries, and these were supplemented by numerous bilateral arrangements "for the provision of such assistance in extreme circumstances." But such obligations had mostly been undertaken during the

\footnotetext{
${ }^{271}$ Changes in Eastern Europe and their influence on the USSR (Moscow, February 1989), [in:] Masterpieces of History. The Peaceful End of the Cold War in Europe, eds. S. Savranskaya, Th. Blanton and V. Zubok, Budapest 2010, pp. 365-381.

${ }^{272}$ J. Reykowski, interviewed by J. Lévesque [in:] J. Lévesque, The Enigma of 1989. The USSR and the Liberation of Eastern Europe, Berkeley 1997, p 112.

${ }^{273}$ Ibidem, p. 113.
} 
Cold War and reflected a "confrontational, forcebased approach to the resolution of contended international issues." They created a damaging "prestige" factor "as a result of which both the USSR and USA frequently were inclined in the past to think not so much about the resolution of emerging conflicts as about fulfilling their military-political obligations." This "automatic mechanism" often pushed the countries into confrontation, sharply reducing the scope for resolving their problems by diplomatic means. ${ }^{274}$

His remedies were radical. Even cursory analysis of Soviet treaties and agreements with other states revealed numerous instances of ambiguity and possible interpretations. This enabled "certain states that have even the most vague guarantees from us, in certain circumstances to exploit them for their own narrow interests without much thought for the security interests of the wider region and of global security as a whole." The problem was even more complicated for the United States "which has incomparably more of these sorts of agreements and treaties than we do." While not abandoning all Soviet obligations to its allies, especially to the socialist countries, Zagladin advocated a thorough review of all requirements to provide military assistance. Following this, confidential discussions should be held with the Americans "to prod the USA into displaying greater caution in taking on and fulfilling its own corresponding obligations." His closing sentences are equally remarkable: "We need to remember that this issue is closely connected with others that are gaining even greater current significance, including weapons exports, naval force activities and the creation of zones of peace and security in various regions. In future, obligations regarding military assistance will as a rule, evidently have to receive the approval of the (Soviet) Supreme Soviet. These are problems to ponder. But the experience and lessons of Afghanistan seem to show, at least to me, that they deserve attention." 275

In response, Gorbachev authorised Zagladin to conduct a critical review of the Soviet Union's "current obligations to provide military assistance to foreign countries, including under extreme circumstances." The ensuing inquiry, by Foreign and Defence Ministers Shevardnadze and Yazov, and the Chairman of the State Foreign Economic Commission Kamentsev, was sent to Gorbachev on 25 March. It repudiated previous Soviet interpretations of Moscow's obligations under the Warsaw Pact and in bi-lateral treaties with East Europe.

They began with a discussion of "extreme circumstances that might trigger military assistance" to a Warsaw Pact country. They related this exclusively to foreign threats, and also noted that individual or collective self-defence against an external threat was already provided for in the UN Charter (Chapter Seven, Article 51). However, two bi-lateral treaties, those with Czechoslovakia and the DDR, did provide for military action "in defence of the peoples' socialist gains." This had been widely understood in the West (and by previous Soviet leaders) as enshrining the right to military intervention. But they insisted that such clauses were very general and definitively did not stipulate that military assistance must be

${ }^{274}$ AGF, Fond No. 3, Dok. 7179, L 1, Dokladnaya zapiska o peresmotre obyazatel'stv po okazaniyu voennoi pomoshchi, pp. 1-2.

275 AGF, Fond No. 3, Dok. 7179, L 1, pp. 3-4. 
provided. ${ }^{276}$ Moreover "internal situations" in allied countries "do not require us to take any sorts of measures in connection with our treaty obligations." Whilst some of the Warsaw Pact's wording was ambiguous, as was that in some bilateral treaties, they did not suggest any initiative to rephrase them 'in the light of difficulties currently being experienced' in some countries. On the contrary, such a move might be counter-productive, "weakening allied relationships, accelerating their centrifugal tendencies and increasing the instability in several countries." Where allies themselves requested a revision, as had Bulgaria, this should be done by bringing bi-lateral treaties into line with the wording used in the Warsaw Pact Treaty on providing military assistance to a country under attack. ${ }^{277}$

The troika did not agree with Zagladin's suggestion of discussing these changes "in strict confidence" with the Americans. This would leak to the US press, and produce a storm, as had happened after the Reagan-Gorbachev discussion in Reykjavik in 1986. This would become known by the East European allies, who would conclude that the super-powers were continuing a condominium at their expense: "The political effect would certainly be very negative." Nonetheless, a positive Soviet-American dialogue should continue, with the aims of reducing confrontation and seeking "constructive approaches to regulate existing or potential problems in various parts of the world." 278 One consequence of conducting this radical revision in strictest secrecy was that Western commentators remained sceptical. The major study of the Brezhnev Doctrine published in 1990, though probably completed in spring 1989, concludes: "It is still too early to write the obituary of the Brezhnev Doctrine." ${ }^{27} 9$

Moscow was quick to hail the success of the Round Table (6 February-5 April) and the Polish opposition was equally quick to understand that democracy was rapidly replacing democratic centralism. As Jan Lityński put it: "However inadvertently, Gorbachev demonstrated to the whole world that the phenomenon of Solidarity in 198081 was not an accidental caper of some undisciplined Poles, but the beginning of a profound crisis, pointing in all probability to the decomposition of the entire system. Today in Eastern Europe, the Soviet ideological umbrella is slowly folding and the threat of Soviet tanks is bit by bit becoming part of the past. Local communists suddenly face their societies alone. For the first time they must make decisions to an extent on their own. The overseer only demands peace and quiet, but does not suggest prefabricated solutions." 280 Solidarity's stunning victory in the 4 June elections - the same day as the massacre in Tiananmen Square- was also endorsed by the Soviet media. A somewhat shocked Polish Party leadership, convened next day, concluded that nothing could be done to reverse the electors' choice. ${ }^{281}$

\footnotetext{
${ }^{276}$ Hoover Archives, Papers of Vitalii Leonidovich Kataev, Box 13, Folder 14 "Tovarishchu Gorbachevu M.S." Memorandum No. 242/OS (Top Secret), pp. 1-2.

${ }^{277}$ Hoover Archives, Papers of Vitalii Leonidovich Kataev, Box 13, Folder 14, pp. 5-6.

${ }^{278}$ Ibidem, p. 9.

${ }^{279}$ R.A. Jones, The Soviet Concept of 'Limited Sovereignty' from Lenin to Gorbachev. The Brezhnev Doctrine, London 1990, p. 261.

${ }^{280}$ J. Lityński, An Historic Turning-Point, "New Politics” 1989, Vol. 2, Part 3.

${ }^{281}$ Tajne dokumenty Biura..., pp. 390-398.
} 
Adam Michnik said "Farewell to the Brezhnev Doctrine" in a signed editorial for his newspaper, which now had a circulation of 420,000. "Last Saturday's television interview with Mikhail Gorbachev presented a new and important emphasis...the repudiation of force and compulsion (dyktat) in relations between the nations of the USSR." This was a moment of great significance for Poland and Polish thinking. "The consequence of abandonment of the Brezhnev doctrine of »limited sovereignty« by Soviet leaders means they are ready for a new projected agreement between »the free with the free and equal with equal«, an agreement between the sovereign state and nation." "Fraternal assistance" had ended the Prague Spring almost 21 years ago. Now "there will be no return to the time of the Brezhnev doctrine." Military interventions, as in Hungary, Czechoslovakia and Afghanistan, will no longer be tolerated. "Our task for Poland is to regain democracy and sovereignty."282

More puzzling, perhaps, than the issue of Cold War endings, is the question why it had lasted so long. Many in central Europe, on both sides of the "iron curtain", came to suspect that the partition of Europe suited the super-powers rather well. Even in the less geographically-salient areas, such as Yugoslavia, they engaged in a complex stand-off, whose main purpose was to deny the territory to the other side. Yet the nuclear underpinning of the stalemate increasingly perturbed the post-war generation, and found increasingly public expression during the anti-war protests from the mid-sixties. Nor was this anxiety confined to the long-haired radicals of the beat and pop generation. We now know that senior military officials within the Warsaw Pact shared some of their concerns. In 1969, the Czechoslovak General Staff considered that any nuclear exchange in central Europe would destroy all those living there: rather than security, they faced the prospect of mutual destruction. ${ }^{283}$ The comforting logic of "deterrence", that each side would restrain the other by promising unacceptable damage in retaliation, seemed a slender hope compared to the certain outcome of an actual exchange. Indeed, Soviet military planners always rejected the notion that a nuclear war could remain "limited". MAD was not sane.

Insecurities were not confined to strategic studies. Economic disparities between Eastern and Western Europe, most visible in Berlin, became increasingly apparent across the "blocs". The Stalinist command economy, which had been an effective means to launch industrialisation in the first place and an instrument with which to focus the national effort on a single goal, such as winning the war, was unable to compete with Western dynamism and ability to innovate. Falling economic growth had raised a difficult ideological dilemma for successive Soviet leaders. Khrushchev's bold talk about "catching up and overtaking" looked threadbare by the seventies when the Brezhnev team embarked on a charm offensive to acquire grain, credits and technology from the West. The final stage in this offensive was what his biographer Grachev calls "Gorbachev's last gamble."

282 A. Michnik, Pożegnanie doktryny Breżniewa, "Gazeta Wyborcza” 4 July 1989, p. 1.

${ }^{283}$ V. Mastny, Was 1968 a Strategic Watershed of the Cold War?, "Diplomatic History" 2005, Vol. 29 (1). 
His aspirations for a "common European house" were set out in a speech to the Strasbourg parliament (6 July). After stating that the European states belonged to different social systems, and giving no indication that the gains of socialism were reversible, Gorbachev declared "Social and political orders of certain countries changed in the past and may change again in future." That was exclusively the choice of the countries concerned. He then removed what remained of the Brezhnev Doctrine. "Any attempts to limit the sovereignty of states - including friends and allies (italics added), or anyone else - are impermissible." ${ }^{284}$

Gorbachev elaborated his new "political philosophy of international relations" at a Warsaw Pact summit (7-8 July):

1. Super-power disarmament. There should be a Soviet-American agreement to cut strategic offensive weapons by $50 \%$, and strict adherence to the (1972) ABM Treaty. The Warsaw Pact sought to eliminate all chemical weapons.

2. Apan-European Home. There needed to be unity in Europe from the Atlantic to the Urals, with equal dialogue and contacts across the continent. There should be no attempt to destabilise any socialist country or undermine the East-West confidence-building measures already agreed.

3. Troop withdrawals in Europe. The USSR was ready to co-ordinate with allies the size of Soviet redeployments from Eastern Europe. Withdrawals should take into consideration political, military and geographical factors. The US proposal for equal ceilings on superpower deployments in Europe should be considered in a broader context.

4. A second "Helsinki-type meeting". This should review all three "baskets" from 1975. It was time to speed up the process of building security in Europe. There should be joint programmes with Western Europe on transport, environment, technology, nuclear power safety and other common issues.

As Solidarity, the outright winner in partiallyfree elections, prepared to form a government, Jaruzelski was asked about Moscow's attitude towards his Party leaving power. He replied "I don't know what the Russian reaction will be". Hitherto Poland had taken decisions in the foreknowledge of what Moscow would accept, but now they had reached a new boundary. He did not know how long they could stay there without crossing it. ${ }^{285}$ Rakowski decided to ask. In a fortyminute phone call, Gorbachev was unequivocal: "I said one could not alter the situation with the help of a state of emergency, Gorbachev agreed that a new version of the »state of war « was now impossible. However difficult, we would have to resolve the situation without resorting to such measures." ${ }^{286}$ Reporting to the Politburo, Gorbachev cited Rakowski as saying "socialism can be secured without dictatorial methods". He had added that living in a democracy without bread was impossible. ${ }^{287}$

\footnotetext{
${ }^{284}$ M. Kramer, Beyond the Bręhnev Doctrine. A New Era in Soviet-East European Relations?, "International Security" Winter 1989/90, Vol. 14, No. 3, p. 41.

${ }^{285}$ Rok 1989. Bronistaw Geremek, opowiada, Jacek Żakowski pyta, Warszawa 1990, pp. 249-250.

${ }^{286}$ Rakowski Diaries, Hoover Institution Archives, East European Collections, Stanford.

${ }^{287}$ AGF, Fond No.10, opis' No. 2, Politburo, Conversation with Rakowski, 12 October 1989.
} 
Warsaw Pact Ambassadors had been summoned to the Romanian Foreign Ministry (on the night of 19-20 August) to receive a demarche concerning Poland. Ceausescu's proposal was to annul Poland's elections "in favour of the interest of the working class". Taking the bizarre case of Panama, where elections had been cancelled on the grounds that the US had influenced the result, he proposed the Polish vote be set aside. Should this not be done, Warsaw Pact intervention should do so. ${ }^{288}$ The contrast with Romania's stance in 1968 could not be starker. In 1989, Poland regained its sovereignty, and returned to its place in Europe, without Romanian assistance.

When Gorbachev awoke to find the Berlin Wall had fallen (9 November), he concluded that this was the result of "a mass movement that could not be held back by any government." Political control of the armed forces was immediately discussed. The 350,000 Soviet soldiers in the DDR were confined to barracks and told that the fall of the Wall could not be reversed by military intervention. Since other options were limited, the Soviet Politburo made a virtue of necessity. After telling their East German counterpart to avoid bloodshed, they informed the world's press that Krenz's decision on "border and travel regulations" had been a "correct, clever and wise." The same line was taken with Western leaders. Gorbachev's message to Kohl (10 November) called for a calm response. There would be no repetition of the Soviet intervention of June 1953. But he also called for Western restraint to avoid "destabilisation of the situa- tion not only in the centre of Europe but also beyond". Similar verbal messages were transmitted to Mitterand, Thatcher and George Bush.

Secretary of State James Baker sent Moscow a message that the US welcomed the changes in East and Central Europe, but was not hoping for instability there, nor seeking to gain advantages at Soviet expense. It was a decisive moment: East German society had spoken and politicians could but react. Chernyaev noted: "The main thing is the DDR, the Berlin Wall. For it has not only to do with »socialism« but with a shift in the world balance of forces. This is the end of Yalta, of the Stalinist legacy and the »defeat of Hitlerite Germany." This is what Gorbachev has done. And he has indeed turned out to be a great leader. He has sensed the pace of history and helped it to find a natural channel." 289

Dashichev is specific about the Doctrine's demise. "On 26-27 October 1989, when the revolutionary processes in East and Central Europe were in full swing, the Council of Foreign Ministers of the Warsaw Pact confirmed the right »of all peoples to self-determination and free choice of its social, political and economic development without interference from outside." This was the death blow to the Brezhnev Doctrine." 290

He wonders whether withdrawal from Eastern Europe was premeditated. Did Gorbachev and Shevardnadze fully anticipate the consequences of their rejecting conservative demands "to deploy special strike and defence divisions on the frontiers in order to save the DDR and to prevent reunification?" Had they come to realise

5288 "Gazeta Wyborcza” 29 September 1989.

${ }^{289}$ NSA, Notes of Anatoly Chernyaev, 10 November 1989.

${ }^{290}$ V. Dashichev, On the Road..., p. 175. 
that being "the policeman and oppressor of East and Central Europe" put an intolerable burden on the Soviet economy? Or did they simply realise that the position of dominance in the region could not be sustained and thus "yield to new exigencies and realities"? He does not answer these questions directly, but does applaud the peaceful outcome. Shevardnadze considered the use of military force could result in a third world war. Dashichev considered "the use of military force in the DDR could have meant the end of perestroika, a return of neo-Stalinism, and the fall of Gorbachev. It is to Gorbachev and Shevardnadze's credit that they were well aware of the worst consequences of using force on German soil and chose to avoid it." 291

When Gorbachev met Chancellor Kohl (28 October), Chernyaev felt they were entering a new world. He made no claim for the originality of Gorbachev's "new thinking" and saw it simply as common sense. But its provenance was remarkable. Gorbachev, 'who came out of Soviet MarxismLeninism, Soviet society conditioned from top to bottom by Stalinism, began to carry out these ideas with all earnestness and sincerity when he became head of state. No wonder that the world is stunned and full of admiration. And our public still cannot appreciate that he has already transferred all of them from one state to another."292

The issue of force arose one final time. Following the massacre of peaceful protestors in Timisoara by the Romanian army and Securitate (18-20 December), the position of Ceausescu was challenged. ${ }^{293}$ He condemned Moscow for fomenting the uprising, but Washington did not concur. On the contrary, the US Ambassador, Jack Matlock, informed the Soviet Foreign Ministry that if the protesting Romanian National Salvation Front requested military assistance from Moscow, the United States would not oppose such intervention. "Under present circumstances the military intervention of the Soviet Union in Romanian affairs might not be regarded in the context of the Brezhnev Doctrine." In reply, the Deputy Foreign Minister Aboimov categorically ruled out such intervention, even as a theoretical possibility. He noted sardonically: "The American side may now consider that the Brezhnev Doctrine is their gift to us." 294

In her outstanding study of post-cold war options, Mary Sarotte posits four possible models:

1. The Soviet restoration model. Under this, the Yalta/Potsdam four-power condominium would be reconstituted in Europe, including the quadripartite Allied Control Commission over a divided Germany. Each member of the quartet would pursue their own political and economic interests in their own "spheres".

2. The Kohl revivalist model. This revived the nineteenth century Confederation of German States, in the form of two twenty-first century German states. Whilst each would retain their own social and political orders, sovereignty would be shared for purposes of international relations.

\footnotetext{
${ }^{291}$ Ibidem, p. 175.

${ }^{292}$ NSA, Excerpt from Anatoly Chernyaev's Diary, 28 October 1989.

${ }^{293}$ J. Eyal, Why Romania could not avoid bloodshed [in:] Spring in Winter. The 1989 Revolutions, ed. G. Prins, Manchester1990.

${ }^{294}$ Four Soviet Foreign Ministry Documents regarding the Situation in Romania 20-25 December 1989 [in:] Masterpieces of History..., pp. $661-667$.
} 
3. Gorbachev's heroic model. Here his notion of a Common Europe Home would be transformed into reality. Within it, states would retain their own political systems, but cooperate in the military and economic fields from the Atlantic to the Urals.

4. The Western, and particularly West German, prefab model. Rather than creating new institutions (as in 3), existing Western institutions would move eastwards. Earlier expansions of NATO and the European Union would thus accelerate and eventually reach the western borders of an excluded Soviet Union. ${ }^{295}$ German reunification would be the catalyst of this process.

Gorbachev and his advisors imagined the "wind of democratic change" from Moscow would be met in Eastern Europe with gratitude supposedly similar to that which greeted the Red Army during the liberation from Nazi occupation. Both Chernyaev and Shakhnazarov had fought in the Second World War and their shock at finding a different reality was a difficult experience. ${ }^{296}$ Having been victorious in the world war, the Soviet Union had failed to win the postwar peace in Eastern Europe, and was on its way to defeat in the Cold War.

\section{References}

Alexander Dubcek's Recollections of the Crisis, 10 August 1990 [in:] The Prague Spring 1968, ed. J. Navratil, Budapest 1998

I. Aleksandrov, Attack on the Socialist Foundations of Socialism of Crechoslovakia, "Pravda" 11 July 1968

G. Arbatov, The System: An Insider's Life in Soviet Politics, New York 1992

C. Bekes, The 1956 Hungarian Revolution and World Politics, "Cold War International History Project” Paper 16, Washington 1996

P. Bender, East Europe in Search of Security, London 1972

G. Bernardini, Forced to Cooperate. The Brandt Government and the Nixon Administration on the Road to Helsinki [in:] Perforating the Iron Curtain. European Détente, Transatlantic Relations, and the Cold War, 1965-1985, eds. P. Villaume, A. Westad, Copenhagen 2010

S. Bialer, The Soviet paradox: external expansion, internal decline, London 1986

L. Brezhnev, Rabochi i dnevnikove zapisach V 3-x tomach, Moscow 2016

L.I. Brezhnev, V Zjazd PZPR. Stenogram. Warszawa 11-16 XI 1968 r., Warszawa 1969

Z. Brzeziński, Power and Principle. Memoirs of the National Security Adviser 1977-1981, London 1983

N.I. Bukharin et al, O prichinakh $i$ suchnosti krisia 1980 g. v PRN, Moscow 1981

H. Bull, The Anarchical Society. A Study of Order in World Politics, London 1977

Cable to Moscow from Soviet Ambassador to Warsaw Averki Aristov, 16 April 1968 [in:] The Prague Spring 1968, ed. J. Navratil, Budapest 1998

Cable from the Soviet Ambassador in Warsaw, 22 May 1968 [in:] The Prague Spring 1968, ed. J. Navratil, Budapest 1998

${ }^{295}$ M. Sarotte, 1989. The Struggle to Create Post-Cold War Europe, Princeton 2009.

${ }^{296}$ A. Grachev, Gorbachev's Gamble. Soviet Foreign Policy and the End of the Cold War, Cambridge 2008, p. 171. 
S. Carrillo, 'Eurocommunism' and the State, London 1977

Changes in Eastern Europe and their influence on the USSR (Moscow, February 1989), [in:] Masterpieces of History. The Peaceful End of the Cold War in Europe, eds. S. Savranskaya, Th. Blanton and V. Zubok, Budapest 2010

A. Chernyaev, Byl li u Rossii shans? On poslednij, Moscow 2003

A. Chernyaev, Moia Zhizn' i Moye Vremia, Moscow 1995

S.F. Cohen, Bukharin and the Bolshevik Revolution: A Political Biography, 1888-1938, New York 1975

Committee of Ministers of Defence, Moscow [in:] A Cardboard Castle? An Inside History of the Warsaw Pact, 1955-1991, eds. V. Mastny and M. Byrne, Washington / Zurich 2005

CPSU Politburo, 7 February 1980, “Cold War International History Project Bulletin" 1996, Vol. 8/9

Czzechoslovak News Agency, 14 March 1968 [in:] Winter in Prague. Documents on Czechoslovak Communism in Crisis, ed. R. Remington, Cambridge 1969

V. Dashichev, On the Road to German Reunification: A View from Moscow [in:] Soviet Foreign Policy 1917-1991, ed. G. Gorodetsky, London 1994

K. Dawisha, The Kremlin and the Prague Spring, Berkeley 1984

M. Dąbrowski, Lubelski Lipiec 1980, Lublin 2000

M. Djilas, Conversations with Stalin, London 1963

Document of Great Historical Significance, "Pravda" (editorial), 3 July 1956

Dresden Communiqué, "Pravda" 25 March 1968

B. Dudek, T. Marszałkowski, Walki uliczne w PRL, 1956-1989, Kraków 1999

A. Dubček, Hope dies last. The Autobiography of Alexander Dubček, New York 1993
Editorial, "Pravda" 24 January 1982

J. Eisler, Aneks 3, Notatka posiedzenia Biura Politycznego 5 lipca 1968 r. [in:] Wokót praskiej wiosny. Polska i Czechostowacja w 1968 roku, ed.

L. Kamiński, Warszawa 2004

R.D. English, Russia and the Idea of the West. Gorbachev, Intellectuals, and the End of the Cold War, New York 2000

J. Eyal, Why Romania could not avoid bloodshed [in:] Spring in Winter. The 1989 Revolutions, ed. G. Prins, Manchester 1990

F. Fejto, Epilogue [in:] idem, A History of the People's Democracies. Eastern Europe Since Stalin, London 1971

Four Soviet Foreign Ministry Documents regarding the Situation in Romania 20-25 December 1989 [in:] Masterpieces of History. The Peaceful End of the Cold War in Europe, eds. S. Savranskaya, Th. Blanton and V. Zubok, Budapest 2010

R. Gates, From the Shadows: The Ultimate Insider's Story of Five Presidents and how they won the Cold War, New York 1966

Ch. Gati, Failed Illusions. Moscow, Washington, Budapest and the 1956 Hungarian Revolt, Stanford 2006

"Gazeta Wyborcza" 29 September 1989

A. Gerrits, The Failure of Authoritarian Change. Reform, Opposition and Geo-Politics in Poland in the 1980s, Dartmouth 1990

M. Gorbachev, Memoirs, London 1996.

M. Górny, Wydarzenia marcowe w opinii czechostowackiej [in:] Marzec 1968. Trzydzieśsi lat póżniej, Vol. 1 Referaty, Warszawa 1998

A. Grachev, Gorbachev's Gamble. Soviet Foreign Policy and the End of the Cold War, Cambridge 2008

P. Green, Third Round in Poland, "New Left Review" 1977, I/102-102, February-April 
A.I. Gribkov, 'Doktrina Brez̧hneva' i pol'skii krizis nachala 80-kh godov, "Voenno-istoricheskii zhurnal" 1992, No 9

A. Gromyko, On the International Position and Foreign Policy of the Soviet Union, "Pravda" 28 June 1968

Grudzien 1970 w dokumentach MSW, ed. J. Eisler, Warszawa 2000

A.M. Haig, Caveat: Realism, Reagan, and Foreign Policy, London 1984, p. 90.

K. Hamilton, Cold War by other means. British diplomacy and the conference on security and cooperation in Europe, 1972-1975 [in:] The Making of Détente, Eastern and Western Europe in the Cold War, 196575, eds. W. Loth and G. Soutou, London 2008

N. Harding, Lenin's Political Thought, Vol 1 Theory and Practice in the Democratic Revolution, London 1977

N. Harding, Lenin's Political Thought, Vol. 2 Theory and Practice in the Socialist Revolution, London 1981

R. Hill, Soviet politics, political science and reform, London 1980

F.H. Hinsley, Power and the Pursuit of Peace. Theory and Practice in the History of Relations between States, Cambridge 1967

J. Holzer, Solidarność 1980-81. Geneza i historia, Warszawa 1983

The Ideas of Nikolai Bukharin, ed. A. Kemp-Welch, Oxford 1991

J. Reykonski, interviewed by J. Lévesque [in:] J. Lévesque, The Enigma of 1989. The USSR and the Liberation of Eastern Europe, Berkeley 1997

W. Jaruzelski, Stan wojenny. Dlaczego..., Warszawa

W. Jaruzelski, Commentary, "Cold War International History Project Bulletin” 1998, Issue 11

R.A. Jones, The Soviet Concept of 'Limited Sovereignty' from Lenin to Gorbachev. The Brezhnev Doctrine, London 1990

B. Kaliski, „Antysocjalistyczne そbiorowisko”? I Krajowy Zjazd Delegatów NSZZ Solidarność, Warszawa 2003
S. Kania, Zatrzymać konfrontacje, Warszawa 1991

A. Kemp-Welch, Dethroning Stalin. Khrushchev's 'Secret Speech' and Polish Politics, The Spring of 1956, "Europe-Asia Studies" 2006, Vol. 48 (2)

A. Kemp-Welch, The Birth of Solidarity: The Gdansk Negotiations, Oxford 1980

A. Kemp-Welch, The Birth of Solidarity: The Gdansk Negotiations, sec. ext. ed., Oxford 1991

$\mathrm{K}$. Kersten, The Establishment of Communist Rule in Poland, 1943-1948, Berkeley 1991

B. Kopka, G. Majchrzak, Stan wojenny w dokumentach wtadz PRL (1980-1983), Warszawa 2001

S. Kovalev, Marxism and the Contemporary Ideological Struggle, "Pravda" 25 April 1968

S. Kovalev, Suverenitet $i$ internatsional'nye objazannosti sotsialisticheskikh stran, "Pravda" 26 September 1968

L. Kowalski, Kryptonim „Dunaj”: Udziat wojsk polskich w interwencji zbrojnej w Czechostowacji w 1968 roku, Warszawa 1992

L. Kowalski, KOK wobec opozycjipolitycznej i Kościoła w latach 80-tych, "Zeszyty Historyczne" 1995, No. 113

M. Kramer, Gorbachev and the demise of east European communism [in:] Reinterpreting the End of the Cold War. Issues, interpretations, periodizations, eds. S. Pons, F. Romero, London 1994

M. Kramer, The Kremlin, the Prague Spring, and the Brezhnev Doctrine [in:] Promises of 1968. Crisis, Illusion, and Utopia, ed. V. Tismaneanu, Budapest 2011

M. Kramer, The Demise of the Soviet Bloc, "EuropeAsia Studies" 2011, Vol. 63 (9

M. Kramer, The 'Malin Notes' on the Crises in Hungary and Poland, 1956, "Cold War International History Project Bulletin” 1996-1997, Vol. 8/9

M. Kramer, New Evidence on the Polish Crisis, 19801981, “Cold War International History Project Bulletin” 1998, Issue 11 
M. Kramer, Poland, 1980-81. Soviet Policy During the Polish Crisis, "Cold War International History Project Bulletin” 1995, Issue 5

M. Kramer, CPSU CC Politburo Report "On Theses for the discussion with representatives of the Polish leadership”, 3 September 1980, "Cold War International History Project Bulletin" 1995, Issue 5

M. Kramer, Soviet Deliberations during the Polish Crisis, 1980-1981, "Cold War International History Project Special Working Paper” 1999, No. 1

M. Kramer, The Anoshkin Notebook on the Polish Crisis, December 1981, “Cold War International History Project Bulletin” 1998, Issue 11

M. Kramer, Beyond the Brezhnev Doctrine. A New Era in Soviet-East European Relations?, "International Security” Winter 1989/90, Vol. 14, No. 3

S. Kudryashov, Diplomatic Prelude [in:] Stalinism in Poland, 1944-1956: Selected Papers from the Fifth World Congress of Central and East European Studies, ed. A. Kemp-Welch, LondonNew York 1999

M. Kula, Wychodzenie po angielsku, "Krytyka. Kwartalnik Polityczny” 1991, No. 34/35

R. Laba, The Roots of Solidarity. A Political Sociology of Poland's Working-Class Democratisation, Princeton 1991

M. Leffler, The emergence of an American grand strategy, 1945-1952 [in:] The Cambridge History of the Cold War, Vol. 1 Origins, eds. M. Leffler and O.A. Westad, Cambridge 2010

J.J. Lipski, KOR. A History of the Workers' Defense Committee in Poland, 1976-1981, Berkeley 1985

J. Lityński, Wielkosśc i matość, "Robotnik" 1979, No. (34), Vol. 20, June

J. Lityński, An Historic Turning-Point, "New Politics" 1989, Vol. 2, Part 3

W. Loth, Overcoming the Cold War. A History of Détente, 1950-1991, London 2002
W. Loth, Moscow, Prague and Warsaw: Overcoming the Brezhnev Doctrine, "Cold War History" 2001, Vol. 1 (2)

B. Loveman, No Higher Law: American Foreign Policy and the Western Hemisphere since 1776, North Carolina 2010

R.R. Ludwikowski, Will the Crisis of Communism Begin in Poland?, Stanford 1983

P. Machcewicz, Polski rok 1956, Warszawa 1993

P. Machcewicz, Rebellious Satellite, Poland 1956, Stanford 2009

P. Machcewicz, The Assistance of Warsaw Pact Forces Is Not Ruled Out, "Cold War International History Project Bulletin” 1998, Issue 11

V. Mastny, The Soviet Non-Invasion of Poland in 19801981 and the End of the Cold War, "Europe-Asia Studies" 1999, Vol. 51 (2)

V. Mastny, Was 1968 a Strategic Watershed of the Cold War?, "Diplomatic History" 2005, Vol. 29 (1)

V.A. Medvedev, Razpad. Kak on nazreval v 'mirovoi systeme sotsializma', Moscow 1994

A. Michnik, Pożegnanie doktryny Breżniewa, "Gazeta Wyborcza" 4 July 1989

A. Michta, Red Eagle. The Army in Polish Politics, 1944-1988, Stanford 1990

V. Micunovic, Moscow Diary, London 1980

Z. Mlynár, Night Frost in Prague. The End of Humane Socialism, London 1980

Z. Mlynář, August 1968 [in:] Communist Reformation, ed. G.R. Urban, London 1979

O stanie wojennym w Sejmowej Komisji Odpowiedzialności Konstytucyjnej sprawozdanie Komisji $i$ wniosek mniejszości, wraz z ekspertyzami i opiniami historyków, Warszawa 1997

Official Rumanian Communique on the Military Occupation of Crechoslovakia, "Scinteia" 22 August 1968 [in:] Winter in Prague. Documents on Czechoslovak Communism in Crisis, ed. R. Remington, Cambridge 1969 
Okragły stót, (ed.) K. Dubiński, Warszawa 1999

Open Letter, "Literarni listy" 28 March 1968

Otvechaya na viizov vremeni. Vneshnyaya politika perestroiki: dokumental'nie svidetel'stva. Po zapisyam besed M.S. Gorbacheva c zarubezhnimi deyatelyami i drugim materialam, Moscow 2010

M.J. Ouimet, Conclusion [in:] idem, The Rise and Fall of the Brezhnev Doctrine in Soviet Foreign Policy, Chapel Hill 2003

A. Paczkowski, O stanie wojennym. W sejmowej komisji odpowiedrialności konstytucyjnej, Warszawa 1997

A. Paczkowski, Nastroje przed bitwa, "Zeszyty Historyczne" 1992, No. 100

L. Pajorek, Polska a ,praska wiosna”. Udziat Wojska Polskiego w interwencji zbrojnej w Czechostowacji w 1968 roku, Warszawa 1998

F. Parkinson, The Philosophy of International Relations. A study in the history of thought, London 1977

D. Petrescu, Legitimacy, Nation-Building and Closure: Meanings and Consequences of the Romanian August of 1968 [in:] The Prague Spring and the Warsaw Pact Invasion of Czechoslovakia, 1968. Forty Years Later, ed. M.M. Stolarik, Mundelein 2010

PCI Resolution, "l’Unita” 29 December 1981

Z.A. Pelczynski, Poland: the Road from Communism, Oxford 1983Polska 1986-1989: koniec systemu. Materialy z. miedzynarodowej konferencii, Miedzeszyn, 21-23 październik. 1999, Vol. 1 Referaty, Vol. 2 Dyskusja, Vol. 3 Dokumenty, Warszawa 2002

S. Perzkowski (A. Paczkowski), Tajne dokumenty Biura Politycznego i Sekretariatu KC. Ostatni rok władzy 1988-1989, Londyn 1994

Polish TV, 30 November 1988, 19.00 GMT

Politburo of the Bulgarian CP Central Committee, 25 October 1980

Political Consultative Committee, Warsaw [in:] A Cardboard Castle? An Inside History of the Warsaw Pact, 1955-1991, (eds.) V. Mastny and M. Byrne,
Washington / Zurich 2005

Postanie do ludzi pracy w Europie Wschodniej, "Tygodnik Solidarność" 1981, No. 25, 18 September Progress and Outcome of the 14th Meeting of the Defence Ministers Committee, appended to A. Paczkowski and $A$. Werblan, On the Decision to introduce martial law in Poland. Two historians report to the Commission on Constitutional Oversight of the Polish Sejm, "Cold War International History Project Working Paper" 1997, No. 21

M. Rakowski, Jak to sie stało, Warszawa 1991

Rakowski Diaries, Hoover Institution Archives, East European Collections, Stanford

Recepcja Ostpolitik w RFN i w krajach bloku komunistycznego: Polska, ZSRR, NRD, Czechostowacja,

Wegry, eds. J. Fiszer, J. Holzer, Warszawa 2004 Reply to Pravda, "l’Unita" 26 January 1982

Report of a Confidential Discussion with Warsaw Pact

Supreme Commander, DDR Ministry of Defence, 7 April 1981

Report of Gomutka (22 November 1956) [in:] Tajne dokumenty Biura Politycznego. PRL-ZSRR 19561970, ed. A. Paczkowski, Londyn 1998

M. Retegan, In the Shadow of the Prague Spring. Romanian Foreign Policy and the Crisis in Czechoslovakia, 1968, Portland 2000

Rok 1989. Bronisław Geremek opowiada, Jacek Żakowski pyta, Warszawa 1990

Rozmowy z. władzami PRL. Arcybiskup Dabrowski, (ed.) P. Raina, Warszawa 1995, p. 256.

M. Sarotte, Dealing with the Devil. East Germany, Détente, and Ostpolitik, 1969-1973, Chapel Hill 2001

M. Sarotte, 1989. The Struggle to Create Post-Cold War Europe, Princeton 2009

G. Shakhnazarov, Tsena Svobody: reformatsiya Gorbacheva glazami ego pomoshchnika, Moscow 1993

H.G. Skilling, Czechoslovakia's Interrupted Revolution, Princeton 1976 
H.G. Skilling, Charter 77 and Human Rights in Crechoslovakia, London 1981

G.-H. Soutou, Convergence theories in France during the 1960s and 1970s [in:] The Making of Détente, Eastern and Western Europe in the Cold War, 196575, eds. W. Loth and G. Soutou, London 2008

A. Sovetov, The Contemporary Stage of the Struggle between Socialism and Imperialism [in:] Mezhdunarodnaya zhizn', Moscow 1968

A. Stelmachowski, Ksztattowanie sie ustroju III Rzeczpospolitej, Warszawa 1998

Stenogram [in:] W.G. Pawtow, Generat Pawtow: bytem rezydentem KGB w Polsce, Warszawa 1994

V. Stepanov, The Leading Force in the Construction of Communism, "Izvestiya" 11 May 1968

D. Stola, Kampania antysyjonistyczna w Polsce, 19671968, Warszawa 2000

Statement by the Communist and Workers' Parties of Socialist Countries, "Pravda" 4 August 1968

W. Suleja, Dolnoślaski Marzec '68. Anatomia protestu, Warszawa 2006

Tajne dokumenty Biura Politycznego. PRL-ZSRR, 1956-1970, ed. A Paczkowski, Londyn 1998

Tajne dokumenty Biura Politycznego. Grudzieñ 1970, ed. P. Domański (A. Paczkowski), Londyn 1991

D.C. Thomas, The Helsinki Effect. International Norms, Human Rights, and the Demise of Communism, Princeton 2001

“Trybuna ludu” 13 July 1968

N. Tucker, China under Siege: Escaping the Dangers of 1968 [in:] 1968: The World Transformed, eds. C. Fink, Ph. Gassert and D. Junker, Cambridge 1998

A. Tymowski, Widziane z, wewnatrz, "Polityka", 20 June 1987

L. Vaculik, 2,000 words to Workers, Farmers, Scientists, Artists, and Everyone, "Literarny listy" 27 June 1968
Vladimirov, "Pravda" 21 June 1985

A. Walicki, Notes on Jaruzelski's Poland [in:] Crisis and Reform in Eastern Europe, eds. F. Feher, A. Arat, London 1991

L. Wałęsa, A Path of Hope, Londyn 1987

Warsaw Pact summit, 5-6 December 1980

E. Weit, Eyewitness. The Autobiography of Gomulka's Interpreter, London 1973

Wejda nie wejda. Polska 1980-1982: wewnętrany kryzys, miedzynarodowe uwarunkowania. Konferencja w Jachrance listopad 1997, Londyn 1999

O.A. Westad, The Road to Kabul: Soviet Policy on Afghanistan, 1978-1979 [in:] The Fall of Detente: Soviet-American Relations During the Carter Years, ed. O.A. Westad, Oslo 1997

Ph. Windsor, A. Roberts, Czechoslovakia 1968. Reform, Repression and Resistance, London 1969

Winter in Prague. Documents on Czechoslovak Communism in Crisis, ed. R. Remington, Cambridge 1969

Z. Włodek (A. Paczkowski) (ed.), Tajne dokumenty Biura Politycznego. PZPR a „Solidarnośc”, 19801981, Londyn 1992

Wojna z. narodem widziana od srodka, interview with Ryszard Kuklinski, "Kultura” (Paris) 1987, No. 4

\section{Hungarian National Archives}

288.f.5/815.o.e., Report to the Politburo, 8 December 1980 (authorised by Kadar)

\section{Polish Archive of Modern Acts (AAN)} in Warsaw

AAN, BIBS Information Bulletin (44) (secret) 10, October 1957

AAN, 237/ XIA/33

AAN, 237/XVI/586, Wydarzenia marcowe, 6 February 1968

AAN, 237/XVIII/319, Walne zebranie Oddriału Warszanskiego Zwiazku Literatów Polskich (29.11.1968) 
AAN, 237/VII, Informacja nr. 9/A/4346, Odglosy na temat ekscesów na Uniwersytecie Warszanskim, 10 March 1968

AAN, KC PZPR, tom 1, paczka 298

AAN, 237/X1A

AAN, KC PZPR, tom 24, paczka 193

AAN, KC PZPR, p. 119, tom 54, Protokót ze spotkania partyjno-rzqdowych delegacji Butgarii, NRD, Polski, Wegier i ZSSR (Moskwa 24-26 sierpnia 1968 r.)

AAN, KC PZPR, tom 54, p. 119

AAN, 237/VII/5790 t. 1, KC PZPR: Do wszystkich organizacji partyjnych, 21 August 1968

AAN, 237/VII/5790 t. 1, 21 August 1968

AAN, 237/VII/5790 t. 1, Niektóre fakty $i$ wydarzenia na terenie wojewódžtw, 23 August 1968, p. 328

AAN, 237/VII/5790 t. 1, Zachowanie obywateli czechostowackich na terenie Polski, 23 August 1968, p. 313-314

AAN, 237/VII/5790 t. 2, Przejawy wrogiej driałalności w kraju, 26 August 1968, pp 364-365

AAN, 237/X1/367, t. 73, Speech to Central Committee, 29 August 1968

AAN, 237/X1/213, 3 September 1968

AAN, 237/V/1816 Protocol no. 13, 18 July 1980

AAN, 237/V/1816 Protocol no. 16, 14 August 1980

AAN, 237/V/1816 Protocol no. 20, 20 August 1980

AAN, 237/V/1816 Protocol no. 24, 24 August 1980

AAN, 237/V/1816 Protocol no. 26, 27 August 1980

AAN, 237/V/1816, 27 August 1980, evening

AAN, 237/V/1816 Protocol no. 28, 29 August 1980

AAN, 237/V/1816, Conference of First Secretaries of the CC PZPR, 16 September 1980

AAN, 237/V/ 3976, (Kania)

AAN, 237/V/2254, Secretariat, 25 October 1980

AAN, 237/V/3982, Kania's Secretariat, Speech of 16 January 1981

AAN, 237 /V/83, Secretariat, 4 April 1987
The National Security Archive (NSA) in Washington

NSA, Special Coordinating Committee, 23 September 1980

NSA, Letter from Leonid Brezhnev to Eric Honecker, 4 November 1980

NSA, 'Soviet Flashpoints' Collection, CIA Situation Report "Poland", 7 December 1980

NSA, Volkogonov Collection, Reel 17, Container 25, Conference with Central Committee Secretaries, Moscow, 15 March 1985

NSA, Chernyaev, Diary for 1985, 5 July

NSA, Chernyaev Diary for 1987, 5 July

NSA, Chernyaev Diary for 1987, 17 September

NSA, Chernyaev Diary for 1988, 24 April

NSA, Chernyaev Diary for 1988, 31 December

NSA, Notes of Anatoly Chernyaev, 10 November 1989

NSA, Excerpt from Anatoly Chernyaev's Diary, 28 October 1989

\section{Russian state archives (TsKhSD)}

TsKhSD, Fond 89, opis' 42, delo 31, CPSU Politburo, 29 October 1980

TsKhSD, Fond 89, opis' 42, delo 35, "On the Results of a visit to the USSR", CPSU Politburo, 31 October 1980

TsKhSD, Fond 89, opis' 66, delo 37, Protocol of the Politburo CPSU, 3 September 1980

RGANI, Fond 1, opis' 72, delo 201, 2 September 1968

RGANI, Fond 2, opis' 3, delo 568, Plenum TsK KPSS 18 Noyabr' $1981 \mathrm{~g}$.

RGANI, Fond 3, opis' 72, delo 214, 28 October 1968

RGANI, Fond 89, opis' 42, delo 36, CPSU Politburo, 22 January 1981

RGANI, Fond 89, opis' 42, delo 39, CPSU Politburo, 2 April 1981 
Otvechaya na vuizov vremeni, Vneshnyaya politika perestroiki: dokumental'nie svidetel'stva, Tenth Congress PZPR, Warsaw, 30 June 1986

Otvechaya na vuizov vremeni, Politburo, 3 July 1986

Otvechaya na viizov vremeni, Politburo, 11 July 1986,

Otvechaya na vuizov vremeni, Conversation with Jaruzelski, 21 April 1987

Otvechaya na vuizov vremeni, Conversation with Milos Jakes, Kremlin, 11 January 1988

Otvechaya na vuizov vremeni, Politburo, On the secret Soviet-German Protocols of 1939, 5 May 1988

Archive of the Gorbachev Foundation (AGF)

AGF, Fond No. 1, opis' No. 1, 6 April 1988

AGF, Fond No. 1, opis' No. 1, 14 July 1988

AGF, Fond No. 1, opis' No. 1, 25 August 1988

AGF, Fond. No.1, opis’ No. 1, 23 September 1988

AGF, Fond. No.1, opis’ No. 1, 21 October 1988

AGF, Fond No. 3, Dok. 7179, L 1, Dokladnaya zapiska o peresmotre obyazatel'stv po okazaniyu voennoi pomoshchi

AGF, Fond No. 3, Dok. 7179, L 1

AGF, Fond 5, Gorbachev to the Politburo, 26 June 1986
AGF, Fond No. 10, opis' No. 2, Politburo, Conversation with Rakowski, 12 October 1989

The Hoover Institution at Stanford University Hoover Archives, Papers of Vitalii Leonidovich $\mathrm{Ka}$ taev, Box 13, Folder 14

Hoover Archives, Papers of Vitalii Leonidovich Kataev, Box 13, Folder 14 "Tovarishchu Gorbachevu M.S.” Memorandum No. 242/OS ('Top Secret)

Lyndon B. Johnson Presidential Library, Austin, Texas

Lyndon B. Johnson Presidential Library, Files of Walt W. Rostow, Box 11, 19 August 1968

Lyndon B. Johnson Presidential Library, Files of Walt W. Rostow, Box 15, 20 August 1968

Lyndon B. Johnson Presidential Library, Tom Johnson's Notes of Meetings, Box 3

Lyndon B. Johnson Presidential Library, Ranch Meeting, 10 August 1968

Lyndon B. Johnson Presidential Library, Cabinet, 22 August 1968 